UNIVERSIDADE DE SÃO PAULO

FACULDADE DE MEDICINA DE RIBEIRÃO PRETO

DEPARTAMENTO DE PUERICULTURA E PEDIATRIA

MARIANA MORAES DE OLIVEIRA

Desenvolvimento e análise do leite humano concentrado com leite humano liofilizado:

Estudo experimental pré-clínico

Ribeirão Preto 
MARIANA MORAES DE OLIVEIRA

Desenvolvimento e análise do leite humano concentrado com leite humano liofilizado: Estudo experimental pré-clínico

\section{Versão Corrigida}

Tese apresentada à Faculdade de Medicina de Ribeirão Preto da Universidade de São Paulo para obtenção do título de Doutora em Ciências.

Programa: Saúde da Criança e do Adolescente Área: Saúde da Criança e do Adolescente

Orientador: Prof. Dr. José Simon Camelo Junior

Ribeirão Preto 
Autorizo a reprodução e divulgação total ou parcial deste trabalho, por qualquer meio convencional ou eletrônico, para fins de estudo e pesquisa, desde que citada a fonte.

Oliveira, Mariana Moraes de

Desenvolvimento e análise do leite humano concentrado com leite humano liofilizado: Estudo experimental pré-clínico. Ribeirão Preto, 2021. $69 \mathrm{p}$.

Tese de Doutorado, apresentada à Faculdade de Medicina de Ribeirão Preto/USP. Área de concentração: Saúde da Criança e do Adolescente. Orientador: Camelo Junior, José Simon.

1. Leite humano. 2. Liofilização. 3. Nutrientes. 
Nome: OLIVEIRA, Mariana Moraes de

Desenvolvimento e análise do leite humano concentrado com leite humano liofilizado: Estudo experimental pré-clínico

Tese apresentada à Faculdade de Medicina de Ribeirão Preto da Universidade de São Paulo para obtenção do título de Doutora em Ciências.

Aprovado em: 18 de junho de 2021.

Banca Examinadora

Profa. Dra.: Ana Paula de Carvalho Panzeri Carlotti.

Instituição: Faculdade de Medicina de Ribeirão Preto da Universidade de São Paulo. Julgamento: Favorável.

Profa. Dra.: Daniela Saes Sartorelli.

Instituição: Faculdade de Medicina de Ribeirão Preto da Universidade de São Paulo. Julgamento: Favorável.

Profa. Dra.: Daniela Marques de Lima Mota Ferreira.

Instituição: Universidade Federal de Uberlândia.

Julgamento: Favorável. 
Dedico este trabalho à minha mãe e ao meu pai, pelo amor, apoio e incentivo incondicional. 


\section{AGRADECIMENTOS}

A Deus, por sempre me guiar pelo melhor caminho.

Ao meu pai e minha mãe, pelo amor, apoio e incentivo incondicional.

Aos meus familiares e amigos, que me apoiam e incentivam o desenvolvimento do meu potencial latente, ou seja, das melhores qualidades e valores próprios da natureza humana.

Ao meu grande mestre e orientador Prof. Dr. José Simon Camelo Junior, pela oportunidade de parceria e pelo exemplo profissional, apoio e incentivo ao longo do meu processo de desenvolvimento profissional acadêmico.

À amiga Profa. Tânia M.B. Trevilato, pelo carinho, aconselhamento, apoio, incentivo e comprometimento com a realização deste trabalho.

Aos Profa. Dra. Susana I. Segura-Muñoz, Prof. Dr. Martí Nadal, Prof. Dr. Jordi Sierra, Dra. Montse Marquès e Prof. Dr. José L. Domingo, pela oportunidade de parceria e pelo apoio, incentivo e comprometimento com este trabalho.

Ao amigo Dr. Davi C. Aragon, estatístico do Departamento de Puericultura e Pediatria (FMRP-USP), pela paciência e pelo apoio e comprometimento na realização deste trabalho.

À Faculdade de Medicina de Ribeirão Preto e Universidade de São Paulo, pela oportunidade de realização deste curso de pós-graduação.

À Fundação CAPES, pela concessão da bolsa que permitiu a realização deste trabalho.

Ao Banco de Leite Humano, especialmente à diretora Larissa G. Alves e farmacêutica Vanessa S. Bomfim, e também ao Hospital das Clínicas da Faculdade de Medicina de Ribeirão Preto (Universidade de São Paulo) pela oportunidade de coleta de dados desse trabalho.

Finalmente, às doadoras de leite humano que foram essenciais para execução do estudo. 


\section{INSTITUIÇÕES E FONTES FINANCIADORAS}

Esta tese é resultado de extensa pesquisa com material biológico humano aprovada pelo Comitê de Ética em Pesquisa do Hospital das Clínicas da Faculdade de Medicina de Ribeirão Preto - USP, Parecer no 738.080, de 11/07/2014.

Este estudo foi desenvolvido no Banco de Leite Humano e Laboratório de Pediatria (Seção de Metais e Doenças Raras), ambos do Hospital das Clínicas da Faculdade de Medicina de Ribeirão Preto da Universidade de São Paulo. Além disso, este estudo teve a parceria das seguintes instituições: Laboratório de Ecotoxicologia e Parasitologia Ambiental da Escola de Enfermagem de Ribeirão Preto, Universidade de São Paulo; Laboratório de Toxicologia e Saúde Ambiental, Universitat Rovira i Virgili (Espanha); Laboratório de Ciência do Solo, Universitat de Barcelona (Espanha).

A execução dos projetos e as publicações foram financiadas pela Fundação Bill e Melinda Gates (Grand Challenges Brazil), Bolsa nº OPP1107597 para JSC Jr., CNPq Conselho Nacional de Desenvolvimento Científico e Tecnológico, Brasil, Bolsa $n^{\circ} 401612$ / 2013-9 a JSC Jr. e Ministério da Saúde / Departamento de Ciência e Tecnologia, Brasil.

O presente trabalho foi realizado com apoio da Coordenação de Aperfeiçoamento de Pessoal de Nível Superior - Brasil (CAPES) - Código de Financiamento 001.

Os financiadores não tiveram nenhum papel no desenho dos estudos, coleta e análise de dados, decisão de publicação ou preparação dos manuscritos. 
"O vento do meu espírito soprou sobre a vida. $\mathcal{E}$ tudo que era efêmero se desfez. E ficaste só tu, que és eterno ..." (Cecília Meireles) 


\section{RESUMO}

OLIVEIRA MM. Desenvolvimento e análise do leite humano concentrado com leite humano liofilizado: Estudo experimental pré-clínico [tese]. Ribeirão Preto: Universidade de São Paulo, Faculdade de Medicina de Ribeirão Preto; 2021.

Introdução: $O$ suporte nutricional do recém-nascido prematuro tem sido alvo constante de estudos nos últimos anos devido, principalmente, à sua contribuição para maior sobrevivência do recém-nascido pré-termo e de muito baixo peso (RNMBP) ao nascer $(<1500 \mathrm{~g})$. O leite materno foi consagrado como recurso padrão ouro para alimentação do RNMBP. As recomendações atuais enfatizam que o RNMBP deve receber o leite da própria mãe como primeira escolha e, quando não disponível, a segunda opção é o leite humano (LH) doado fortificado com aditivos comerciais específicos. A maioria de tais aditivos têm como matéria prima o leite de vaca, ou seja, uma fonte de proteína heteróloga para o organismo humano a qual está associada ao aumento da morbimortalidade do RNMBP. Diante disso, a hipótese desta tese é que o LH doado possa ser liofilizado e utilizado como aditivo natural do próprio LH e, com isso, aumentar a concentração de macro e micronutrientes essenciais a fim de atender as necessidades nutricionais do RNMBP. Objetivos: Desenvolver um LH concentrado a partir da adição do LH liofilizado e analisar a segurança microbiológica, a osmolalidade, o valo energético e a composição de macro e micronutrientes essenciais além de elementos potencialmente tóxicos. Métodos: O LH concentrado foi desenvolvido por meio dos processos de liofilização, reconstituição e pasteurização. A avaliação da segurança microbiológica foi obtida por meio do teste simplificado de detecção de coliformes totais. A osmolalidade foi obtida pelo método "Osmometria de Ponto de Congelamento". O valor energético e o teor de macronutrientes foram determinados pela técnica de espectroscopia no infravermelho em equipamento denominado Human Milk Analyzer MIRIS. O teor de micronutrientes foi determinado pela técnica de espectrofotometria de absorção atômica com chama e método colorimétrico automatizado. $\mathrm{O}$ teor dos elementos potencialmente tóxicos foi determinado pela técnica de espectrometria de massa com plasma indutivamente acoplado. Resultados: Artigos publicados em revistas científicas indexadas. Conclusão: Esta tese comprova a formulação do LH concentrado a partir de método direto, simples, pouco oneroso e isento de viés ético de liofilização do LH doado e sua utilização como aditivo natural do próprio LH.

Palavras-chave: Leite humano. Liofilização. Nutrientes. 


\section{ABSTRACT}

OLIVEIRA MM. Development and analysis of human milk concentrated with human milk lyophilized: Pre-clinical experimental study [thesis]. Ribeirão Preto: Universidade de São Paulo, Faculdade de Medicina de Ribeirão Preto; 2021.

Introduction: The nutritional support of premature newborns has been a constant target of studies in recent years, mainly due to its contribution to greater survival of preterm and very low birth weight newborns (VLBW) at birth $(<1500 \mathrm{~g})$. Breast milk has been established as the gold standard resource for feeding the VLBW. Current recommendations emphasize that the VLBW should receive the mother's own milk as the first choice, however, when not available, the second option is human milk (HM) donated fortified with specific commercial additives. Most of these additives are based on cow's milk that contains a heterologous protein source to the human organism, which is associated with increased morbidity and mortality of VLBW. Therefore, the hypothesis of this thesis is that the HM donated can be lyophilized and used as a natural additive of HM and increase the concentration of essential macro and micronutrients in order to meet the nutritional needs of VLBW. Aim: Develop a HM concentrated from the addition of HM lyophilized and analyze the microbiological safety, osmolality, energy value and composition of essential macro and micronutrients, in addition to potentially toxic elements. Method: HM concentrated was developed through lyophilization, reconstitution and pasteurization. The evaluation of microbiological safety was obtained through the simplified test for detection of total coliforms. Osmolality was obtained by the "Freezing Point Osmometry" method. The energy value and the macronutrient content were determined by the infrared spectroscopy technique in equipment called Human Milk Analyzer MIRIS. The micronutrient content was determined by flame atomic absorption spectrophotometry technique and automated colorimetric method. The content of potentially toxic elements was determined by the inductively coupled plasma mass spectrometry technique. Results: Articles published in indexed scientific journals. Conclusion: This thesis proves the formulation of HM concentrated using a direct, simple, inexpensive and ethically free method of lyophilization of HM donated and its use as a natural additive to HM itself.

Keywords: Human milk. Lyophilization. Nutrients. 


\section{LISTAS DE ABREVIATURAS E SIGLAS}

$\begin{array}{ll}\text { AAP } & \text { Academia Americana de Pediatria } \\ \text { BLH } & \text { Banco de Leite Humano } \\ \text { EN } & \text { Enterocolite Necrosante } \\ \text { FMRP } & \text { Faculdade de Medicina de Ribeirão } \\ \text { HC } & \text { Hospital das Clínicas } \\ \text { LH } & \text { Leite Humano } \\ \text { OMS } & \text { Organização Mundial da Saúde } \\ \text { rBLH } & \text { Rede de Bancos de Leite Humano } \\ \text { rBLH-BR } & \text { Rede Brasileira de Bancos de Leite Humano } \\ \text { RNMBP } & \text { Recém-Nascido pré-termo e de Muito Baixo Peso } \\ \text { USP } & \text { Universidade de São Paulo } \\ \text { UTIN } & \text { Unidade de Terapia Intensiva Neonatal }\end{array}$




\section{SUMÁRIO}

1 INTRODUÇÃÕ

1.1 Recém-nascido pré-termo e de Muito Baixo Peso (RNMBP)...............................13

1.2 Nutrição do RNMBP.....................................................................................14

1.3 Nutrição enteral precoce exclusiva com Leite Humano (LH).............................15

1.4 Aditivos específicos para LH...................................................................................16

1.5 Justificativa e hipótese do estudo.......................................................................17

1.6 Objetivos geral e específicos....................................................................................................18

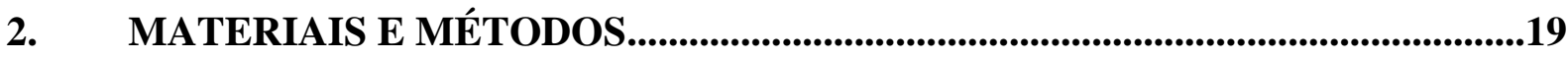

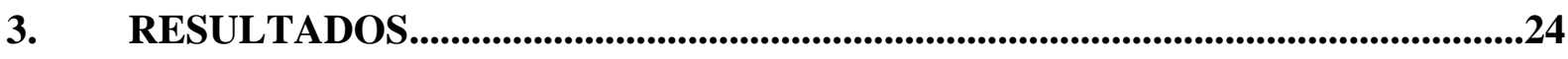

3.1 Capítulo 1..........................................................................................................................25

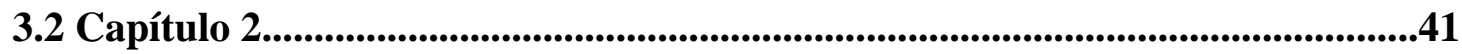

4. DISCUSSÃ

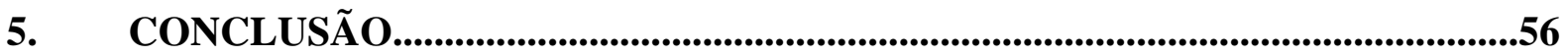

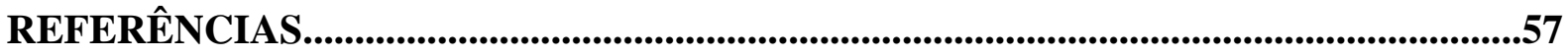

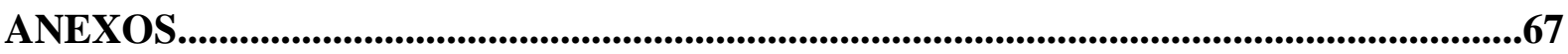




\section{INTRODUÇÃO}

\subsection{Recém-Nascido pré-termo e de Muito Baixo Peso (RNMBP)}

A taxa de nascimento prematuro está aumentando em todo o mundo (Chang; Tseng; Chen, 2020; WHO, 2012). O nascimento prematuro, de acordo com a Organização Mundial da Saúde (OMS), ocorre quando os nascidos vivos não completaram 37 semanas de idade gestacional (WHO, 2012, 2019). Tal desfecho de nascimento pode ser causado por vários fatores categorizados em socioeconômicos, demográficos, comportamentais, complicações obstétricas, saúde reprodutiva da mulher além de condições médicas e nutricionais do binômio mãe-bebê (Laelago; Yohannes; Tsige, 2020). Sendo assim, a incidência mundial de nascimento prematuro é bastante variável, porém significativamente mais elevada nos países com recursos financeiros escassos e alta taxa de fertilidade como na África Subsaariana e no sul da Ásia (Purisch; Gyamfi-Bannerman, 2017). Entretanto, países como Índia, China, Brasil e Estados Unidos também têm apresentado um número alarmante de nascimentos prematuros, o que demonstra ser um problema significativo em todos os contextos de renda (WHO, 2019). Estimase que no ano de 2014 a taxa mundial de nascimento prematuro foi de 9 a 12\% (12,65 a 16,73 milhões) dentre os nascidos vivos, ou seja, mais de 1 em cada 10 bebês nasceram prematuros no mundo (Chawanpaiboon et al., 2019; Laelago; Yohannes; Tsige, 2020; WHO, 2012).

Os recém-nascidos pré-termo apresentaram maior risco de morbidades e, consequentemente, mortalidade (Chang; Tseng; Chen, 2020; WHO, 2019). A cada ano, no mundo, cerca de 2,5 milhões de recém-nascidos morrem durante os primeiros 28 dias de vida, sendo que, aproximadamente $80 \%$ desses nasceram com baixo peso e dois terços nasceram prematuramente. Felizmente, de acordo com a OMS, a taxa global de mortalidade neonatal diminuiu nos últimos anos (WHO, 2019). Estudo de coorte de nascimentos realizado no Brasil ratifica os dados da OMS e destaca que a mortalidade dos recém-nascidos pré-termo e de muito baixo peso ao nascer $(<1500 \mathrm{~g})$ diminuiu nos últimos 33 anos, entretanto, enfatiza que tais prematuros ainda contribuem com mais da metade dos óbitos neonatais (Victora et al., 2018).

A redução da mortalidade do recém-nascido pré-termo deve-se aos notáveis avanços técnico-científicos aplicados aos cuidados obstétricos e neonatais durante o pós-natal imediato (Hay, 2008; Victora et al., 2018). A maior sobrevivência do recém-nascido pré-termo está relacionada ao melhor uso de antibióticos, à reanimação neonatal, ao controle da temperatura e redução do estresse por hipotermia, à nutrição adequada que inclui o aleitamento materno, ao controle de líquidos e eletrólitos e ao uso de oxigênio, surfactante e respirador neonatal 
(Harrison; Goldenberg, 2016). Tais informações sustentam o fato da taxa de sobrevivência do recém-nascido pré-termo ser mais alta em países desenvolvidos, ou seja, com alta renda e que dispõem de melhores recursos aplicados no cuidado neonatal (Purisch; Gyamfi-Bannerman, 2017; Victora et al., 2018; WHO, 2019). Entretanto, muitos recém-nascidos pré-termo ainda morrem devido à falta de atendimento adequado em diversos países de baixa e média renda (Chawanpaiboon et al., 2019). Portanto, é necessário o contínuo aprimoramento e fortalecimento do cuidado neonatal para melhorar cada vez mais a sobrevivência e o bem-estar do recém-nascido pré-termo, especialmente em países subdesenvolvidos de baixa e média renda (Chawanpaiboon et al., 2019; deRegnier, 2018).

\subsection{Nutrição do RNMBP}

O suporte nutricional do recém-nascido pré-termo tem sido alvo constante de estudos nos últimos anos devido, principalmente, à sua contribuição para maior sobrevivência do prematuro extremo $(<28$ semanas de idade gestacional) e com peso muito baixo $(<1500 \mathrm{~g})$ ao nascer (Harding et al., 2017; Hay, 2008; McNelis; Fu; Poindexter, 2017). Além disso, estratégias para otimizar o cuidado nutricional desempenham um papel importante no crescimento, na redução das morbidades e no neurodesenvolvimento a longo prazo desses recém-nascidos pré-termo (Belfort; Ehrenkranz, 2017; Horbar et al., 2015).

A otimização da nutrição do recém-nascido pré-termo tem como objetivo, além de promover a sobrevivência, permitir que esse recém-nascido extremamente imaturo cresça e se desenvolva como se ainda estivessem no ambiente intra-uterino (Asbury et al., 2019; Hay, 2008; Villar et al., 2015). Sendo assim, os padrões de crescimento pós-natal do recém-nascido pré-termo devem ser os mesmos que o de um feto normal de mesma idade gestacional que cresce no ambiente intra-uterino (AAP, 1985; Villar et al., 2015). Entretanto, apesar dos esforços nos últimos anos para otimizar o suporte nutricional praticado na Unidade de Terapia Intensiva Neonatal (UTIN), muitos recém-nascidos com 501-1500g apresentam déficit de crescimento pós-natal (Horbar et al., 2015).

O déficit de crescimento pós-natal do RNMBP durante o período de hospitalização inicial está relacionado às exigências nutricionais elevadas, ao aporte insuficiente de nutrientes e à fisiopatologia das morbidades associadas à prematuridade (Asbury et al., 2019; Hay, 2008; Martinez; Camelo Jr, 2001).

O nascimento prematuro impede que o recém-nascido vivencie parte ou todo o último trimestre gestacional e, com isso, o crescimento e desenvolvimento que deveriam ocorrer neste 
período são prejudicadas. Assim, quanto mais acentuada a prematuridade e menor o peso de nascimento, maiores são as dificuldades enfrentadas pelo recém-nascido devido suas limitações morfofuncionais, morbidades e ao estresse associados à prematuridade (Martinez; Camelo Jr, 2001). Com isso, o crescimento de RNMBP é dificultado por problemas fisiopatológicos relativamente frequentes como hipotensão, hipóxia, acidose, infecções, intervenções cirúrgicas, além de tratamentos farmacológicos com corticosteroides, e também pela imaturidade fisiológica como a limitada motilidade gastrintestinal (Hay et al, 1999).

A nutrição adequada é fundamental para prevenir o retardo do crescimento pós-natal precoce e otimizar o crescimento e o neurodesenvolvimento a curto e longo prazo dos recémnascidos pré-termo (Belfort; Ehrenkranz, 2017; Embleton; Pang; Cooke, 2001). Portanto, o crescimento e a maturação estrutural satisfatórios, particularmente das estruturas cerebrais, exigem o aporte quantitativo e qualitativo adequado de nutrientes visando evitar deficiências nutricionais assim como indesejáveis sobrecargas metabólico-digestivas (AAP, 1985; CMAJ, 1995; Coviello et al., 2018).

Suprir as necessidades nutricionais do RNMBP é um desafio visto que a prematuridade exige uma demanda aumentada de energia, proteína e micronutrientes essenciais tais como Ferro, Zinco e Cálcio devido ao baixo estoque corporal e rápido potencial de crescimento pósnatal do recém-nascido pré-termo (Agostoni et al., 2010; Kumar et al., 2017; Raiten; Steiber; Hand, 2016). Sabe-se que o aporte aumentado de energia e proteínas durante a primeira semana pós-natal está associado ao melhor neurodesenvolvimento e crescimento aos 18 meses de recém-nascidos com baixo peso (Stephens et al., 2009). Além disso, a ingestão de energia durante a primeira semana de vida também está associada ao crescimento até a idade corrigida de 2 anos de recém-nascidos extremamente prematuros (Hiltunen et al., 2018). Sendo assim, existe uma correlação positiva entre a nutrição enteral precoce adequada e o crescimento, a maturação cerebral e o neurodesenvolvimento de recém-nascidos pré-termo (Cormack et al., 2020; Coviello et al., 2018; Martin et al., 2009; Miller et al., 2014).

\subsection{Nutrição enteral precoce exclusiva com Leite Humano (LH)}

A nutrição enteral precoce exclusiva com LH é considerada uma estratégia segura, vantajosa e econômica para o suporte nutricional do RNMBP visto que está associada à redução da incidência de Enterocolite Necrosante (EN), da mortalidade neonatal e também dos custos e do tempo de hospitalização desses recém-nascidos pré-termo (Assad; Elliott; Abraham, 2016; Colaizy et al., 2016; Cortez et al., 2018; Sullivan et al., 2010). 
O leite materno fornece nutrientes ideais e fatores bioativos de proteção que auxiliam o desenvolvimento dos sistemas imunológico e gastrointestinal, além de apoiar o neurodesenvolvimento a longo prazo do RNMBP (Andreas; Kampmann; Le-Doare, 2015; Brown; Walsh; McGuire, 2019; Patra et al., 2017; Sammallahti et al., 2017; Walker, 2010). Apesar de alguns estudos afirmarem que a alimentação com fórmula alimentar artificial resulta em maior ganho de peso e melhor crescimento linear e da circunferência da cabeça do recémnascido pré-termo, tal fórmula também está associada ao aumento do risco de desenvolvimento de EN (Quigley; Embleton; McGuire, 2019). Importante destacar que a terapia com LH durante o período de hospitalização está associada ao melhor neurodesenvolvimento do RNMBP aos 18-20 meses de idade corrigida (Patra et al., 2017; Vohr et al., 2006). Assim, diante dos benefícios dos componentes nutricionais e bioativos do LH, o aleitamento materno foi consagrado como recurso padrão ouro para alimentação do recém-nascido pré-termo (AAP, 2012; Andreas; Kampmann; Le-Doare, 2015; Mosca; Giannì, 2017; Walker, 2010).

As recomendações atuais enfatizam que o recém-nascido pré-termo deve receber o leite da própria mãe como primeira escolha (Dutta et al., 2015; Kumar et al., 2017). Entretanto, as mães de recém-nascidos pré-termo internados na UTIN frequentemente apresentam produção tardia e limitada de leite materno durante as primeiras semanas após o parto (Ikonen et al., 2018; Sethi et al., 2017). Sendo assim, quando o leite da própria mãe não estiver disponível, a segunda escolha é o LH doado ao Banco de Leite Humano (BLH), pasteurizado e, quando clinicamente permitido e/ou necessário, enriquecido com aditivos comerciais específicos para LH (Bertino et al., 2013; Colaizy et al., 2012; Quigley; Embleton; McGuire, 2019; Valentine et al., 2017).

\subsection{Aditivos específicos para LH}

A imaturidade estrutural e funcional do sistema gastrointestinal do RNMBP não permite que o prematuro tolere o volume de LH capaz de suprir as quantidades necessárias de nutrientes, principalmente energia e proteínas, para garantir o seu adequado crescimento e desenvolvimento durante o período de internação na UTIN (Harding et al., 2017; SeiiediBiarag; Mirghafourvand, 2020). Assim, a alimentação predominante com LH cru ou pasteurizado pode ser nutricionalmente insuficiente para o RNMBP culminando em déficits de crescimento e ganho de peso, além de outras complicações relacionadas à subnutrição aguda (Colaizy et al., 2012; Quigley; Embleton; McGuire, 2019). Embora os benefícios nutricionais e imunológicos do LH para o recém-nascido pré-termo já estejam bem estabelecidos, diversos autores defendem a necessidade de fortificação do LH com aditivos específicos com intuito de 
fornecer nutrientes na quantidade e qualidade ideais para promover o adequado crescimento e desenvolvimento do RNMBP (Colaizy et al., 2012; Harding et al., 2017; Kumar; Yadav, 2019; Schanler et al., 2018).

Tradicionalmente, os produtos comerciais utilizados como aditivos de LH têm como matéria prima o leite de vaca enriquecido com determinados nutrientes (Arslanoglu et al., 2019; Koo; Tice, 2018). Entretanto, a exposição precoce à proteína do leite de vaca, considerada nutricionalmente heteróloga para o organismo humano, está associada ao déficit de crescimento pós-natal, à maior intolerância alimentar e ao aumento de morbidades como EN cirúrgica e não cirúrgica (Assad; Elliott; Abraham, 2016; Ganapathy; Hay; Kim, 2012; Sullivan et al, 2010).

Recentemente, por meio de técnicas avançadas de lacto-engenharia, os aditivos específicos para o LH derivados exclusivamente do próprio LH foram desenvolvidos com a finalidade de evitar a utilização dos produtos derivados da proteína do leite de vaca e, com isso, reduzir a morbidade e mortalidade do recém-nascidos pré-termo associada ao consumo de proteína heteróloga (Premkumar; Pammi; Suresh, 2019; Sullivan et al, 2010). Apesar de vários estudos apontarem as vantagens da nutrição exclusiva com LH, incluindo a utilização de aditivos à base de LH, pouco se discute a respeito das questões éticas e do custo elevado envolvidos na comercialização de tais produtos provenientes de substância humana, ou seja, matéria prima biológica humana (Arslanoglu et al., 2019; Assad; Elliott; Abraham, 2016; Sullivan et al., 2010). Atualmente, a empresa privada norte americana Prolacta Bioscience ${ }^{\circledR}$ é a única que produz e comercializa aditivos à base de LH, segundo dados disponíveis em https://www.prolacta.com. Entretanto, considerando a realidade econômica das UTINs públicas e as legislações vigentes brasileiras, a utilização dessa única opção disponível de aditivos exclusivamente à base de LH é considerada economicamente inviável além de eticamente questionável (Brasil, 2006, 2016).

\subsection{Justificativa e hipótese do estudo}

Estudos realizados previamente demonstram que há a possibilidade de desenvolver aditivos líquido, creme e em pó derivados exclusivamente do LH por meio de vários processos de manipulação desse leite tais como a remoção da lactose e a liofilização (Grance et al., 2015; Lucas et al., 1980; Thomaz et al., 2012).

A hipótese da presente tese é que o LH doado ao BLH possa ser liofilizado e utilizado como aditivo natural do próprio LH e, com isso, aumentar a concentração de macronutrientes e micronutrientes essenciais visando atender com qualidade e segurança as necessidades 
nutricionais do RNMBP. A expectativa é que este estudo comprove o desenvolvimento e viabilidade do LH concentrado a partir da liofilização direta do LH doado por meio de um método simplificado e pouco oneroso com etapa final de pasteurização, segundo os critérios da Rede Brasileira de Bancos de Leite Humano (rBLH-BR). Além disso, o propósito desse estudo é demonstrar a possibilidade de implantação do método de liofilização e concentração do LH na rotina da $\mathrm{rBLH}-\mathrm{BR}$, gerando assim uma alternativa viável ao uso dos aditivos comerciais à base de proteína do leite de vaca atualmente utilizados nas UTINs brasileiras. Secundariamente, os resultados deste estudo permitirão atualizar as informações a respeito da composição do leite materno maduro proveniente de doadoras brasileiras.

\subsection{Objetivos geral e específicos}

O objetivo geral deste estudo foi desenvolver um LH concentrado pasteurizado a partir da adição do LH liofilizado com adequada segurança microbiológica, osmolalidade e composição nutricional a fim de ser utilizado como recurso para o suporte nutricional do RNMBP durante o período de internação na UTIN. Assim, os objetivos específicos foram:

- Avaliar a segurança microbiológica do LH linha de base e do LH concentrado logo após a pasteurização. Reavaliar a segurança microbiológica do LH concentrado após 6 meses de congelamento $\left(-20^{\circ} \mathrm{C}\right)$.

- $\quad$ Determinar a osmolalidade do LH linha de base e do LH concentrado.

- Determinar o valor energético $(\mathrm{Kcal} / 100 \mathrm{~mL})$ e a concentração dos seguintes macronutrientes no LH linha de base e no LH concentrado: proteína, carboidrato, lipídios totais, sólidos totais e proteína verdadeira;

- Determinar a concentração dos seguintes micronutrientes essenciais no LH linha de base e no LH concentrado: Cálcio $(\mathrm{Ca})$, Cobre $(\mathrm{Cu})$, Cromo $(\mathrm{Cr})$, Ferro $(\mathrm{Fe})$, Fósforo $(\mathrm{P})$, Magnésio (Mg), Manganês (Mn), Potássio (K), Selênio (Se), Sódio (Na) e Zinco (Zn);

- Determinar a concentração dos elementos potencialmente tóxicos no LH linha de base e no LH concentrado: Alumínio (Al), Arsênio (As), Cádmio (Cd), Chumbo (Pb), Estanho (Sn), Mercúrio (Hg), Níquel (Ni) e Tálio (Tl);

- Avaliar a estabilidade da osmolalidade, do valor energético e da concentração de determinados macronutrientes (proteína, carboidrato, lipídios totais, sólidos totais, proteína verdadeira) e micronutrientes ( $\mathrm{Ca}, \mathrm{Mg}, \mathrm{Na}, \mathrm{K}, \mathrm{Cu}, \mathrm{P}$ e $\mathrm{Zn}$ ) essenciais no LH concentrado após 3 e 6 meses de congelamento $\left(-20^{\circ} \mathrm{C}\right)$. 
- Avaliar a adequação das concentrações de macro e micronutrientes essenciais no LH concentrado confrontando a literatura científica atual referente às recomendações nutricionais para recém-nascidos pré-termo.

\section{MATERIAIS E MÉTODOS}

A presente tese foi realizada no BLH e Laboratório de Pediatria (Seção de Metais e Doenças Raras), ambos pertencentes ao Hospital das Clínicas da Faculdade de Medicina de Ribeirão Preto da Universidade de São Paulo (HC-FMRP-USP). Além disso, parte deste estudo teve a parceria das seguintes instituições: Laboratório de Ecotoxicologia e Parasitologia Ambiental da Escola de Enfermagem de Ribeirão Preto, Universidade de São Paulo; Laboratório de Toxicologia e Saúde Ambiental, Universitat Rovira i Virgili (Espanha); Laboratório de Ciência do Solo, Universitat de Barcelona (Espanha). Esta tese foi realizada com material biológico humano e, devido a isso, foi necessária a submissão e aprovação pelo Comitê de Ética em Pesquisa em Seres Humanos do Hospital das Clínicas da Faculdade de Medicina de Ribeirão Preto - USP (Parecer HREC n 738.080).

O LH utilizado neste estudo foi proveniente de doações da produção excedente das doadoras as quais foram informadas sobre a natureza do estudo e, aquelas que se dispuseram a participar, assinaram o "Termo de Consentimento Livre e Esclarecido". Após a triagem clínica e sorológica preconizada pela rBLH-BR, as doadoras consideradas aptas para participarem do estudo receberam orientações sobre como massagear e ordenhar os seios além de como rotular e pré-estocar o LH cru ordenhado em frasco de vidro estéril e inerte previamente fornecido pelo BLH do HC-FMRP-USP (BLH-IFF/NT-09.18; BLH-IFF/NT-16.11; BLH-IFF/NT-17.11; BLH-IFF/NT-18.11). A equipe do BLH em questão foi responsável pelo transporte em caixas isotérmicas, recepção e degelo das amostras de LH cru ordenhado (BLH-IFF/NT-19.11; BLHIFF/NT-20.11; BLH-IFF/NT-21.11; BLH-IFF/NT-24.11).

No BLH do HC-FMRP-USP, as amostras doadas de LH cru ordenhado descongeladas passaram pelos processos de seleção e classificação como determinado pela rBLH-BR (BLHIFF/NT-23.11). Os critérios de seleção incluíram a verificação das condições da embalagem, de sujidades, da cor, do flavor e da acidez Dornic (BLH-IFF/NT-25.11; BLH-IFF/NT-26.11; BLH-IFF/NT-27.11; BLH-IFF/NT-28.11; BLH-IFF/NT-29.11). As amostras que não preencherem os parâmetros de normalidade referentes aos critérios de seleção foram consideradas impróprias para consumo e descartadas como lixo hospitalar (BLH-IFF/NT08.11). 
Os critérios de classificação incluíram a verificação do período de lactação, a acidez Dornic e o conteúdo energético determinado pelo Crematócrito (BLH-IFF/NT-23.11).

A acidez Dornic do LH cru ordenhado foi obtida por meio da acidez titulável determinada com o auxílio de uma solução padrão de hidróxido de sódio $(\mathrm{NaOH})$, um titulante alcalino. A técnica da acidez titulável baseia-se em uma reação estequiométrica entre o titulante alcalino padrão NAOH e os constituintes com caráter ácido presentes no LH cru ordenhado, até a completa neutralização. O ponto final da reação é revelado através de uma solução indicadora que gera uma mudança de cor de acordo com a mudança de $\mathrm{pH}$. Neste estudo, a solução titulante foi o NAOH N/9, também conhecido como Solução Dornic, sendo que cada $0,01 \mathrm{~mL}$ gasto para neutralizar $1 \mathrm{~mL}$ de leite humano ordenhado corresponde a 1 grau Dornic $\left(1^{\circ} \mathrm{D}\right)$. Sendo assim, foram pipetadas 3 alíquotas de $1 \mathrm{~mL}$ da amostra de $\mathrm{LH}$ cru e acondicionadas, respectivamente, em 3 tubos de crioscopia com capacidade para $5 \mathrm{~mL}$. Após a adição de uma gota da solução indicadora de fenolftaleína à cada alíquota, procedeu-se à titulação com o gotejamento de $\mathrm{NaOH}$ N/9. Durante o procedimento, o tubo de ensaio contendo LH foi constantemente e levemente agitado para evitar a incorporação de ar no produto. O procedimento foi interrompido quando ocorreu a viragem do indicador, ou seja, quando o produto assumiu coloração róseoclara. Com isso, a leitura do volume da solução titulante utilizados foi utilizada para determinar a acidez da amostra lembrando que cada $0,01 \mathrm{~mL}$ de $\mathrm{NaOH}$ gasto para neutralizar $1 \mathrm{~mL}$ de leite humano ordenhado correspondeu a $1^{\circ} \mathrm{D}$ (BLH-IFF/NT-29.11).

O Crematócrito foi a técnica analítica empregada para determinação do teor de creme o qual permitiu o cálculo estimado do teor de gordura e do conteúdo energético do leite humano cru ordenhado (BLH-IFF/NT-30.11). A técnica consistiu em homogeneizar manualmente as amostras e pipetar $1 \mathrm{~mL}$ do $\mathrm{LH}$ cru em um tubo de ensaio $(5 \mathrm{~mL})$. Após aquecimento em banhomaria $\left(40^{\circ} \mathrm{C}\right.$ por 15 minutos), as amostras formam homogeneizadas por agitação em vórtex e, em seguida, foram coletadas de forma independente 3 alíquotas com auxílio de tubos capilares com uma das extremidades vedada com massa. Os tubos capilares foram centrifugados por 15 minutos a $3.500 \mathrm{rpm}$ e procedeu-se a leitura em milímetros das colunas de creme e soro formadas. Após a leitura, aplicou-se os resultados nas fórmulas descritas abaixo para obter os valores de \% de Creme, \% de Gordura e Kcal/L. O valor final correspondeu à média aritmética das 3 alíquotas avaliadas.

1. Teor de Creme: Coluna de Creme $(\mathrm{mm}) \times 100 /$ Coluna total $(\mathrm{mm})=\%$ de Creme.

2. Teor de Gordura: $(\%$ Creme $-0,59) \div 1,46=\%$ de Gordura.

3. Conteúdo Energético Total: $(\%$ de Creme x 66,8 + 290) $=\mathrm{Kcal} / \mathrm{L}$. 
Os critérios de inclusão das amostras foram o LH cru ordenhado doado com período de lactação maior que 15 dias, denominado LH cru maduro, e com um valor de acidez Dornic até $8^{\circ} \mathrm{D}$. Considerando um valor de 0,36 para o desvio padrão em relação à média esperada de concentração proteica $(2,20 \mathrm{~g} / \mathrm{dL})$ e um valor de erro absoluto de 0,1 , com nível de confiança de $95 \%$, foi necessário obter 50 amostras. Após o descongelamento do LH cru ordenhado e realização dos procedimentos de seleção e classificação no BLH do HC-FMRP-USP, sob campo de chama, cada amostra de mesma doadora foi subdividida em frascos contendo alíquotas de $80 \mathrm{~mL}, 75 \mathrm{~mL}$ e $50 \mathrm{~mL}$. As alíquotas de $80 \mathrm{~mL}$ foram denominadas " $\mathrm{LH}$ linha de base". As alíquotas de $50 \mathrm{~mL}$ foram congeladas em freezer $-30^{\circ} \mathrm{C}$ por 24 horas, liofilizadas e reconstituídas com as alíquotas de $75 \mathrm{~mL}$ da mesma doadora. Detalhadamente, o processo de liofilização das alíquotas de 50mL congeladas foi realizado utilizando o liofilizador de bancada Lyophilizer L108-LioTop ${ }^{\circledR}$ o qual promoveu a desidratação do LH por sublimação após as amostras terem sido submetidas ao vácuo seguido de aumento gradativo da temperatura. Após 72 horas, as amostras foram retiradas do liofilizador e mantidas em cadeia de frio para serem reconstituídas com $75 \mathrm{~mL}$ do LH da mesma doadora em cabine de segurança biológica e sob campo de chama. Tais amostras foram então denominadas "LH concentrado".

As amostras de LH linha de base e de LH concentrado foram pasteurizadas a fim de assegurar a qualidade sanitária final do LH ordenhado. Assim, a pasteurização foi o tratamento térmico aplicado ao LH ordenhado com o objetivo de inativar $100 \%$ dos microrganismos patogênicos e 99,99\% da microbiota saprófita, que é equivalente a um tratamento para inativação térmica da Coxiella burnetti. Tal tratamento térmico compreendeu um período de pré-aquecimento entre o momento da colocação dos frascos a serem pasteurizados no banhomaria até a estabilização da temperatura a $62,5^{\circ} \mathrm{C}$. Após o pré-aquecimento, os frascos com $\mathrm{LH}$ ordenhado permaneceram em banho-maria a $62,5^{\circ} \mathrm{C}$ por 30 minutos. $\mathrm{O}$ banho-maria utilizado neste estudo não disponha de agitador automático, portanto, o pesquisador responsável pela pasteurização agitou manualmente cada frasco, sem retirá-lo do banho-maria, de 5 em 5 minutos. Transcorridos os 30 minutos relativos à letalidade térmica, foi conduzido o resfriamento dos frascos pela imersão dos mesmos em um banho de água e gelo até que o LH pasteurizado atingisse temperatura $\leq 5^{\circ} \mathrm{C}$ (BLH-IFF/NT-34.11). Imediatamente após o resfriamento das amostras, em cabine de segurança biológica e sob campo de chama, foram coletas pequenas quantidades de cada amostra de LH linha de base e de LH concentrado para a avaliação da segurança microbiológica e determinação da osmolalidade, do valor energético (Kcal/100mL), da concentração de macro e micronutrientes essenciais e também de elementos potencialmente tóxicos. Parte das amostras coletadas foram imediatamente congeladas a $-20^{\circ} \mathrm{C}$ 
para as análises após 3 e 6 meses de armazenamento e também para as análises as serem realizadas no Laboratório de Pediatria (Seção de Metais e Doenças Raras) do Hospital das Clínicas da Faculdade de Medicina de Ribeirão Preto da Universidade de São Paulo (Ribeirão Preto, São Paulo, Brasil) e também no Laboratório de Toxicologia e Saúde Ambiental da Faculdade de Medicina da Universitat Rovira i Virgili (Reus, Catalunha, Espanha).

O controle da qualidade microbiológico das amostras de LH linha de base e LH concentrado pasteurizadas foi realizado no BLH do HC-FMRP-USP por meio do teste simplificado de detecção de coliformes totais seguindo a lógica preconizada para alimentos que institui a utilização de micro-organismos indicadores de qualidade sanitária, como determinado pela rBLH-BR. O método do teste, conduzido em cabine de segurança biológica e sob campo de chama, consistiu no inóculo de quatro alíquotas de $1 \mathrm{~mL}$ cada, pipetadas de forma independente, em tubos com 10mL de Caldo Verde Brilhante (BGBL) a 5\% p/v, com tubos de Durham em seu interior. Após a inoculação e incubação a $36 \pm 1{ }^{\circ} \mathrm{C}$ por $24-48$ horas, a presença de gás no interior do tubo de Durham caracteriza resultado presuntivo positivo. Neste caso, o tubo presuntivo positivo deve ser repicado, com auxílio de alça bacteriológica, para tubos contendo BGBL na concentração de $40 \mathrm{~g} / \mathrm{L}$. Após a incubação destes tubos a $36 \pm 1{ }^{\circ} \mathrm{C}$ por 24 48 horas, a presença de gás confirma a existência de microrganismos do grupo coliforme e caracteriza o LH pasteurizado como impróprio para consumo (BLH-IFF/NT-40.11). Após 6 meses, parte das amostras de $\mathrm{LH}$ concentrado armazenadas a $-20^{\circ} \mathrm{C}$ foram descongeladas em banho-maria a $37^{\circ} \mathrm{C}$ por 15 minutos e reavaliadas quanto a qualidade microbiológica.

A osmolalidade foi determinada nas amostras de LH linha de base e de LH concentrado por meio do método "Osmometria de Ponto de Congelamento" utilizando o equipamento Osmômetro Microprocessado PZL-1000 (PZL) alocado no BLH do HC-FMRP-USP e que gera resultados expressos em mOsm/ $\mathrm{Kg} \mathrm{H}_{2} \mathrm{O}$. Após 3 e 6 meses, parte das amostras de $\mathrm{LH}$ concentrado armazenadas a $-20^{\circ} \mathrm{C}$ foram descongeladas em banho-maria a $37^{\circ} \mathrm{C}$ por 15 minutos e reavaliadas quanto a osmolalidade.

A determinação do valor energético (Expresso em Kcal/100mL) e da concentração dos macronutrientes proteína, carboidrato, lipídios totais, sólidos totais e proteína verdadeira (Expressos em g/100mL) no LH linha de base e no LH concentrado foi realizado por meio do equipamento Human Milk Analyzer MIRIS (Miris, Uppsala, Suécia) alocado no BLH do HCFMRP-USP. As amostras foram aquecidas em banho-maria a $37^{\circ} \mathrm{C}$ por 15 minutos e homogeneizadas com o equipamento Sonicator MIRIS (Miris, Uppsala, Suécia) imediatamente antes de serem inseridas no Human Milk Analyzer MIRIS, o qual realiza análises com base na técnica de espectroscopia no infravermelho. Após 3 e 6 meses, parte das amostras de LH 
concentrado armazenadas a $-20^{\circ} \mathrm{C}$ foram descongeladas em banho-maria a $37^{\circ} \mathrm{C}$ por 15 minutos, sonicadas e reavaliadas quanto a concentração dos macronutrientes acima citados.

A determinação dos micronutrientes essenciais $\mathrm{Ca}, \mathrm{Mg}, \mathrm{Na}, \mathrm{K}, \mathrm{Cu}, \mathrm{Zn}$ e $\mathrm{P}$ foi realizada no Laboratório de Pediatria (Seção de Metais e Doenças Raras) do Hospital das Clínicas da Faculdade de Medicina de Ribeirão Preto da Universidade de São Paulo (Ribeirão Preto, São Paulo, Brasil). Inicialmente congeladas no BLH do HC-FMRP-USP, as amostras foram encaminhadas para o Laboratório de Pediatria e descongeladas em banho-maria à $37^{\circ} \mathrm{C}$. Após sonicação das amostras por 10 minutos, as diluições adequadas foram realizadas de acordo com as curvas de calibração específica para cada micronutriente a ser dosado pela técnica de Espectrofotometria de Absorção Atômica com Chama em equipamento EAA 55B VARIAN no qual se utiliza lâmpadas de catodo oco específicas, exceto para o micronutriente fósforo. $\mathrm{O}$ método colorimétrico automatizado foi utilizado para dosar o P nas amostras.

As concentrações dos micronutrientes essenciais ( $\mathrm{Fe}, \mathrm{Cr}, \mathrm{Mn}$ e $\mathrm{Se}$ ) e dos elementos potencialmente tóxicos ( $\mathrm{Al}, \mathrm{As}, \mathrm{Cd}, \mathrm{Pb}, \mathrm{Sn}, \mathrm{Hg}, \mathrm{Ni}$ e $\mathrm{Tl}$ ) nas amostras de $\mathrm{LH}$ linha de base e LH concentrado foram determinadas pelo Laboratório de Toxicologia e Saúde Ambiental da Faculdade de Medicina da Universitat Rovira i Virgili (Reus, Catalunha, Espanha) após um preparo prévio realizado no Laboratório de Pediatria (Seção de Metais e Doenças Raras) do Hospital das Clínicas da Faculdade de Medicina de Ribeirão Preto da Universidade de São Paulo (Ribeirão Preto, São Paulo, Brasil). Inicialmente congeladas no BLH do HC-FMRP-USP, as amostras foram encaminhadas para o Laboratório de Pediatria e descongeladas em banhomaria à $37^{\circ} \mathrm{C}$. Após sonicação das amostras por 10 minutos, alíquotas de $1 \mathrm{~mL}$ foram digeridas quimicamente com $1 \mathrm{~mL}$ de ácido nítrico Suprapur 65\% (Merck KGaA®, Darmstadt, Alemanha) em recipientes de Teflon hermético os quais foram submetidos à estufa (FANEM®, Modelo 315 SE, São Paulo, Brasil) com temperatura controlada de $80^{\circ} \mathrm{C}$ por 8 horas e posterior resfriamento em temperatura ambiente por 12 horas. As amostras digeridas foram diluídas 1:5 com água ultrapura, acondicionadas em tubos Falcon e enviadas para o Laboratório de Toxicologia e Saúde Ambiental da Faculdade de Medicina da Universitat Rovira i Virgili. Após o recebimento das amostras, os técnicos do Laboratório de Toxicologia realizaram uma diluição 1:5 com ácido nítrico 1\% (Merck KGaA, Darmstadt, Alemanha) e determinaram a concentração de Fe, Cr, Mn, Se, Al, As, Cd, Pb, Sn, Hg, Ni e Tl nas amostras de LH linha de base e LH concentrado por meio da técnica da espectrometria de massa com plasma indutivamente acoplado em equipamento ICP-MS da PerkinElmer ${ }^{\circledR}$ NexION 350D e que gera resultados expressos em $\mu \mathrm{g} / \mathrm{L}$. 
A análise estatística descritiva se propôs a apresentar o valor médio mais o desvio padrão referente a cada análise das dosagens da osmolaridade, do valor energético e dos macronutrientes e micronutrientes essenciais $\mathrm{Ca}, \mathrm{Mg}, \mathrm{Na}, \mathrm{K}, \mathrm{Cu}, \mathrm{Zn}$ e $\mathrm{P}$. Quanto às concentrações dos micronutrientes essenciais e elementos potencialmente tóxicos $\mathrm{Fe}, \mathrm{Cr}, \mathrm{Mn}$, Se, Al, As, Cd, Pb, Sn, Hg, Ni e Tl, a estatística descritiva se propôs a apresentar o valor médio, desvio padrão e valor mínimo e máximo de cada análise. Além disso, modelos lineares bayesianos de efeito misto foram ajustados usando OpenBUGS para estimar a diferença média e intervalos confiáveis de 95\% ao comparar as amostras de LH linha de base e LH concentrado.

\section{RESULTADOS}

A presente tese será apresentada no formato de coletânea de artigos de estudos publicados nas revistas científicas indexadas, multidisciplinares e de acesso livre PLOS ONE e Environmental Research contemplados, respectivamente, nos seguintes capítulos 1 e 2 . As publicações abordam detalhadamente o desenvolvimento do $\mathrm{LH}$ concentrado com LH liofilizado assim como as análises da osmolalidade, da segurança microbiológica, do valor energético e do teor de determinados macronutrientes e micronutrientes essenciais e também elementos potencialmente tóxicos.

\subsection{Capítulo 1}

O capítulo 1 apresenta a publicação na revista PLOS ONE referente ao desenvolvimento do LH concentrado a partir do LH liofilizado e análise da osmolalidade, da segurança microbiológica, do valor energético e do teor de determinados macronutrientes e micronutrientes essenciais (proteína, carboidrato, lipídios totais, sólidos totais, proteína verdadeira; $\mathrm{Ca}, \mathrm{Mg}, \mathrm{Na}, \mathrm{K}, \mathrm{Cu}, \mathrm{P}$ e $\mathrm{Zn}$ ) no LH linha de base e no LH concentrado, seguido de avaliação da estabilidade da segurança microbiológica e da composição nutricional.

\subsection{Capítulo 2}

O capítulo 2 apresenta a publicação na revista Environmental Research referente à determinação da concentração dos micronutrientes essenciais $\mathrm{Cr}$, Fe, Mn e Se além dos elementos traço potencialmente tóxicos $\mathrm{Al}, \mathrm{As}, \mathrm{Cd}, \mathrm{Pb}, \mathrm{Sn}, \mathrm{Hg}, \mathrm{Ni}$ e $\mathrm{Tl}$ no $\mathrm{LH}$ linha de base e no LH concentrado. 


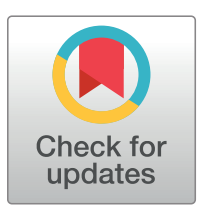

\section{f open Access}

Citation: Oliveira MM, Aragon DC, Bomfim VS, Trevilato TMB, Alves LG, Heck AR, et al. (2019) Development of a human milk concentrate with human milk lyophilizate for feeding very low birth weight preterm infants: A preclinical experimental study. PLoS ONE 14(2): e0210999. https://doi.org/ 10.1371/journal.pone.0210999

Editor: Juan J. Loor, University of Illinois, UNITED STATES

Received: September 18, 2018

Accepted: January 6, 2019

Published: February 20, 2019

Copyright: @ 2019 Oliveira et al. This is an open access article distributed under the terms of the Creative Commons Attribution License, which permits unrestricted use, distribution, and reproduction in any medium, provided the original author and source are credited.

Data Availability Statement: All relevant data are within the manuscript and its Supporting Information files.

Funding: The present study was supported by Bill and Melinda Gates Foundation (Grand Challenges Brazil), Grant \# OPP1107597 to JSC Jr., CNPq Conselho Nacional de Desenvolvimento Científico e Tecnológico, Brazil, Grant \# 401612/2013-9 to JSC Jr., and Ministry of Health / Department of Science and Technology, Brazil. The funders had no role in
RESEARCH ARTICLE

\section{Development of a human milk concentrate with human milk lyophilizate for feeding very low birth weight preterm infants: A preclinical experimental study}

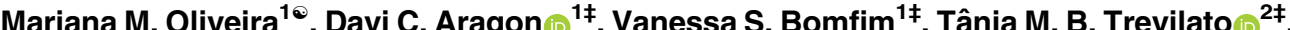
Larissa G. Alves $^{3 \ddagger}$, Anália R. Heck ${ }^{3 \ddagger}$, Francisco E. Martinez ${ }^{4 \ddagger}$, José S. Camelo, Jr ${ }^{40_{*}^{*}}$

1 Department of Pediatrics, Children's Hospital, Ribeirão Preto Medical School, University of São Paulo, Ribeirão Preto, São Paulo, Brazil, 2 Laboratory of Pediatrics, Clinics Hospital of Ribeirão Preto, Ribeirão Preto Medical School, University of São Paulo, Ribeirão Preto, São Paulo, Brazil, 3 Human Milk Bank, Clinics Hospital of Ribeirão Preto, Ribeirão Preto, São Paulo, Brazil, 4 Department of Pediatrics, Neonatology, Children's Hospital, Ribeirão Preto Medical School, University of São Paulo, Ribeirão Preto, São Paulo, Brazil

จ These authors contributed equally to this work. $\ddagger$ These authors also contributed equally to this work.

* jscamelo@fmrp.usp.br

\section{Abstract}

Breast milk is considered the gold standard nutritional resource for very low birth weight (VLBW) infants in terms of nutrients and protective factors. If mother's milk is not available, the second choice is donated and fortified human milk (HM) from the Human Milk Bank (HMB). This study hypothesized that HM could be lyophilized and used as an additive to increase the levels of macronutrients and micronutrients available to VLBW infants. This study aimed to constitute a lyophilized $\mathrm{HM}$ concentrate and determine the osmolality and the concentration of macronutrients and micronutrients in HM samples at "baseline" and in "HM concentrates", analyzed immediately ( $\mathrm{HMCl})$, and after $3(\mathrm{HMC} 3 \mathrm{~m})$ and 6 ( $\mathrm{HMC} 6 \mathrm{~m})$ months of freezing. Osmolality was verified using the freezing point osmometric method. Macronutrient quantification was performed using the MIRIS Human Milk Analyzer. Micronutrients were determined by Flame Atomic Absorption Spectrophotometry and by the automated colorimetric method. Bayesian linear mixed effect models were adjusted using OpenBUGS to estimate mean differences and $95 \%$ credibility intervals ( $\mathrm{Crl}$ ) of osmolality and of macro- and micronutrients between the types of HM samples. A comparison of dosage values showed a significant increase between $\mathrm{HM}$ baseline and $\mathrm{HMCl}, \mathrm{HMC} 3 \mathrm{~m}$, and $\mathrm{HMC6m}$. Comparing $\mathrm{HM}$ baseline and $\mathrm{HMCl}$ highlighted the increase in energy content and the concentration of carbohydrates and total lipids. The $\mathrm{Ca}$ and $\mathrm{P}$ contents increased and the levels of energy, total lipids, and $\mathrm{Cu}$ were reduced in $\mathrm{HMC} 3 \mathrm{~m}$ compared to $\mathrm{HMCl}$. $\mathrm{Ca}$, $\mathrm{Mg}, \mathrm{K}, \mathrm{Zn}$, and $\mathrm{P}$ increased and the levels of energy, total lipids, and Cu were reduced in HMC6m, compared to $\mathrm{HMCl}$. The present study confirms the possibility of formulation and utilization of the immediate concentrate. Partial stability of HM concentrates generated from freeze-drying of donated milk do not recommend storage. 
study design, data collection and analysis, decision to publish, or preparation of the manuscript.

Competing interests: The authors have declared that no competing interests exist.

\section{Introduction}

Despite considerable advances, the optimal nutritional support for very low birth weight infants $(<1500 \mathrm{~g})$ has not yet been found. The current aims of neonatal care include promoting survival as well as mimicking fetal growth and proper neurodevelopment of these extremely immature infants. Providing for the nutritional needs of very low birth weight (VLBW) infants is a challenge since the preterm stage has a higher demand for energy, protein, and other nutrients than other development stages, as infants have low stores of key nutrients such as iron, zinc, and calcium. An adequate supply of energy and protein during the first week of life is associated with improved growth and development up to the post-conceptional age of 2 years. In addition, the physiological immaturity, diseases, and general stress of prematurity means that these infants require even more optimal nutritional support [1-6].

Breast milk is considered the gold standard nutritional resource due to the provision of nutrients and protective factors. Some advantages conferred to VLBW infants improved longterm outcomes of neurodevelopment, immune defenses, development of the microbiota and the gastrointestinal system, and reduced incidence of necrotizing enterocolitis (NEC) and sepsis [7-10]. In addition, early enteral nutrition with an exclusively human milk (HM) diet has proven to be an effective nutritional support strategy for VLBW infants because of its association with lower incidence of NEC, prevention of neonatal infant mortality, and reduction of time and cost of hospital admission with each preterm infant [11-13].

Current guidelines suggest that all preterm infants should receive HM and that the first choice should be the mother's own milk. Nonetheless, HM should be fortified to ensure optimal nutrient intake. If the own mother's milk is not available, the second choice is donated and fortified HM from the Human Milk Bank (HMB). The nutritional content of donated HM by itself may not satisfy the special nutritional needs of VLBW infants, especially for proteins, micronutrients, and energy, thereby jeopardizing the growth and development of these preterm infants [14-17]. A recent study reported that the adequacy of the quantity and quality of protein intake by VLBW infants influences the rate and relative quality of weight gain [18]. Moreover, an inadequate supply of the micronutrients calcium, phosphorus, and zinc can also culminate in deficient growth and development since these nutrients are responsible for maturation and for the functionality of several enzymatic systems [19-20]. Faced with the impossibility of increasing the volume of HM and thus the absorption of nutrients [21], the strategy to adapt this milk to the nutritional needs of VLBW infants is through the fortification of HM with commercial additives to be added to the mother's own milk (raw or pasteurized) or donated HM. However, widely used bovine milk protein-based products, despite providing growth and weight gain to preterm infants, partially alter the immunological quality of HM, increase osmolarity and risk of sensitization by heterologous protein, as well as the occurrence of NEC [22-25]. More recently, human milk-based additives have been formulated and studies show the advantages of their use, such as improved morbidity and mortality rates, less incidence of NEC, decreased hospital stays, and improvement of infant growth and weight gain. Nevertheless, the cost of the product and the ethical questions related to its commercialization make it difficult to use it in neonatal intensive care units (ICUs) [26-29]. Thus, considering the recent scientific breakthroughs, the hypothesis of this study is that HM voluntarily donated to the HMB may be lyophilized, in a simple and effortless way, and used as an additive of HM to increase the levels of nutrients. The aims of this study were to constitute a concentrate with freeze-dried HM and determine the osmolality and the concentration of macronutrients and micronutrients in HM samples immediately and after 3 and 6 months in storage to evaluate the increase in concentration of nutrients followed by nutritional stability of the product. This study reports an innovative and simplified proposal of nutritional support for VLBW infants 
with an exclusive HM diet to be implemented in the routine of the Human Milk Bank Network of Brazil (HMB Network Brazil) to ensure the nutrition of preterm infants and as an alternative to use of the artificial additives currently being used.

\section{Materials and methods}

This research project was carried out through a partnership with the HMB and the Laboratory of Metals and Rare Diseases-Pediatrics, at the Clinics Hospital of Ribeirão Preto, Ribeirão Preto Medical School, University of São Paulo (USP). The milk used in this study came from donations of surplus production of HM, that is, without compromising the child's own feeding. Since this study was carried out with human biological material, it was submitted to and approved by the Human Research Ethics Committee of the Clinics Hospital, Ribeirão Preto Medical School-USP (HREC Report No. 738.080). The donors were informed about the nature of the study and those who were willing to participate in the project signed a free and informed consent form; donors also underwent clinical and serological screening.

\section{Material collection, processing, and quality control}

The donors with a lactation period greater than 15 days were given instructions about massaging and milking their breasts, and about how to withdraw the milk into a sterile, inert glass bottle provided by the HMB. All the samples passed through the selection and classification processes recommended by the HMB Network Brazil (available at: http://www.redeblh. fiocruz.br). The selection process included packaging conditions, presence of dirt, color, offflavor parameters, and Dornic acidity. The classification process included the verification of the lactation period, Dornic acidity, and energetic content-the crematocrit [30-33]. Considering a value of 0.36 for the standard deviation with respect to the expected average of protein concentration $(2.20 \mathrm{~g} / \mathrm{dL})$ and an absolute error value of 0.1 , with a confidence level of $95 \%, 50$ samples were obtained. Additional data were collected to characterize the donors: age, weight, height, Body Mass Index (BMI), and gestational age. Inclusion criteria were surplus mature $\mathrm{HM}$ with a Dornic acidity value of up to $8^{\circ} \mathrm{D}$.

\section{Obtaining the HM concentrate}

For lyophilization, $50 \mathrm{~mL}$ of donated $\mathrm{HM}$ was transferred to an inert, sterile glass container and frozen $\left(-20^{\circ} \mathrm{C}\right.$ for 24 hours). After this period, the frozen sample was placed in the vacuum chamber of a bench lyophilizer (Lyophilizer L108, LioTop, São Carlos-SP-Brazil). After 72 hours, the lyophilized sample was transferred from the lyophilizer to a cold chain, to be reconstituted with HM for use. The concentrate with the HM lyophilizate in the immediate period (HMCI) was composed from samples that were withdrawn from the lyophilizer and reconstituted with $75 \mathrm{~mL}$ of the donor's own HM baseline. These concentrates together with the HM baseline were passed through the processes of pasteurization and microbiological quality control. $\mathrm{HM}$ baseline and $\mathrm{HMCI}$ were pasteurized at $62.5^{\circ} \mathrm{C}$ for 30 minutes after a preheating period [34]. After 30 minutes of thermal treatment that is lethal to pathogenic bacteria, the vials were withdrawn from the bath and cooled until the $\mathrm{HM}$ reached a temperature $\leq 5^{\circ} \mathrm{C}$. For the microbiological quality control check, the pasteurized HM baseline and HMCI samples were screened for total coliforms using bright green bile broth $(50 \mathrm{~g} / \mathrm{L} ; 5 \% \mathrm{w} / \mathrm{v})$ contained within Durham tubes. The concentrate with the HM lyophilizate in the immediate period was subdivided in collection tubes and stored $\left(-20^{\circ} \mathrm{C}\right)$ for $3(\mathrm{HMC} 3 \mathrm{~m})$ and 6 (HMC6) months, to evaluate nutritional stability. Two hundred types of HM samples ( 50 of each type: HM baseline, HMCI, HMC3m, and HMC6m) were analyzed for osmolality, macronutrients, and 
micronutrients. Osmolality verification was performed using the freezing point osmometric method in the PZL-1000 Microprocessed Osmometer (PZL).

\section{Macronutrients}

In the HMB, the 200 types of HM samples were homogenized using a Sonicator MIRIS (Miris, Uppsala, Sweden), and the macronutrient content (protein, carbohydrate, total lipids, total solids and true protein) was quantified in $2 \mathrm{~mL}$ aliquots of each sample type by using the MIRIS Human Milk Analyzer (Miris, Uppsala, Sweden). The MIRIS Human Milk Analyzer performs precise and accurate analyses based on infrared transmission spectroscopy. Sample types HMC $3 \mathrm{~m}$ and HMC6m were previously defrosted in a water bath at $37^{\circ} \mathrm{C}$.

\section{Micronutrients}

After the pasteurization process, aliquots of each type of HM sample were immediately separated in collection tubes, frozen $\left(-20^{\circ} \mathrm{C}\right.$ for 24 hours), and sent to the Laboratory of Metals and Rare Diseases for immediate analysis of micronutrients and also 3 and 6 months post-freezing. The micronutrients Calcium (Ca), Magnesium ( $\mathrm{Mg}$ ), Sodium (Na), Potassium (K), Copper $(\mathrm{Cu})$, Zinc $(\mathrm{Zn})$ and Phosphorus $(\mathrm{P})$ were determined "in natura", after defrosting samples in a water bath at $37^{\circ} \mathrm{C}$ followed by homogenization of the material by ultrasound using Sonicator MIRIS. Proper dilutions were made within the concentration ranges of the calibration curves for readings in the Flame Atomic Absorption Spectrophotometry (EAA 55B VARIAN), in which each element uses a hollow-cathode lamp and specific wavelength, acetylene gas and compressed air. Phosphorus was dosed in the Metrolab equipment with a kit from Wiener Lab., Ref 1382321 by the automated colorimetric method.

\section{Statistical analysis}

The exploratory analysis of osmolality dosages and content of macronutrients and micronutrients was carried out through the mean values (standard deviation) and boxplots (S1 Fig). Bayesian linear mixed effects models were adjusted using OpenBUGS to estimate the mean difference and $95 \%$ credibility intervals when comparing the dosages of osmolality and of the macronutrients and micronutrients between the types of HM sample: HM baseline, HMCI, HMC3m, and HMC6m.

\section{Results}

Fifty HM donors participated in the study. After the selection and classification of the samples according to the inclusion criteria, the mean values (standard deviation) of the Dornic acid values were $4.34^{\circ} \mathrm{D}$ (1.59). The characteristics of the HM donors are summarized in Table 1, in which the mean (standard deviation) age, weight, height, BMI, and gestational age was, respectively, 30.45 (6.05) years, 67.52 (11.92) kg, $1.63(0.59) \mathrm{m}, 25.2(4.39) \mathrm{kg} / \mathrm{m}^{2}$, and $38.43(2.27)$ weeks.

The descriptive dosage results of the mean (standard deviation) of osmolality and content of macronutrients and micronutrients in types of samples HM baseline, HMCI, HMC3m, and HMC6m presented in Table 2. An increase in the levels of the evaluated nutrients was observed in the concentrates of HMCI, HMC3m, and HMC6m, compared to the HM baseline.

The comparative values of dosages of osmolality and of macronutrients and micronutrients in the samples of the types (Table 3 ) show that there was a significant increase in all the parameters in HMCI, HMC3m, and HMC6m, compared to HM baseline. This highlights the 
Table 1. Characteristics of the HM donors.

\begin{tabular}{c|c|c|c|c}
\hline Mothers $(\mathbf{n}=\mathbf{5 0})$ & Mean & Standard Deviation & Minimum & 17 \\
\hline Age (years) & 30.45 & 6.05 & 47 & 44 \\
\hline Weight $(\mathrm{kg})$ & 67.52 & 11.92 & 1.52 & 1.77 \\
\hline Height $(\mathrm{m})$ & 1.63 & 0.59 & 18.1 & 38.1 \\
\hline BMI $\left(\mathrm{kg} / \mathrm{m}^{2}\right)$ & 25.2 & 4.39 & 27 & 42 \\
\hline Gestational age (weeks) & 38.43 & 2.27 & 25 \\
\hline
\end{tabular}

https://doi.org/10.1371/journal.pone.0210999.t001

increase in energy content $(-23.680 ; 95 \% \mathrm{CrI}[-25.910 ;-21.450])$ and the concentration of carbohydrates $(-2.095 ; 95 \%$ CrI $[-2.286 ;-1.912])$ and total lipids $(-1.437 ; 95 \%$ CrI [-1.678; -1.193]). In HMC3m samples, a significant increase was observed in the levels of element $\mathrm{Ca}$ (-2.139; 95\% CrI [-3.356; -0.971]) and P (-1.882; 95\% CrI [-3.618; -0.209]), but a slight reduction in the levels of energy $(2.988 ; 95 \% \mathrm{CrI}[0.689 ; 5.193])$ and total lipids $(0.342 ; 95 \% \mathrm{CrI}$ $[0.099 ; 0.591])$, while the osmolality and other nutrients remained stable, except for $\mathrm{Cu}(7.154$; 95\% CrI [3.840; 10.330]), compared to HMCI samples. In HMC6m samples, a significant increase was observed in the levels of $\mathrm{Ca}(-4.103 ; 95 \% \mathrm{CrI}[-5.325 ;-2.904]), \mathrm{Mg}(-0.357 ; 95 \%$ CrI [-0.515; -0.201]), K (-131.400; 95\% CrI [-193.400; -70.690]), Zn (-47.290; 95\% CrI [-72.040; $-23.100])$, and $\mathrm{P}(-2.022 ; 95 \% \mathrm{CrI}[-3.738 ;-0.355])$, but a slight reduction in the levels of energy (2.672; 95\% CrI [0.417; 4.878]) and total lipids (0.335; 95\% CrI [0.095; 0.579]), while the osmolality and other nutrients remained stable, except for $\mathrm{Cu}(9.040 ; 95 \% \mathrm{CrI}[5.782 ; 12.203])$, compared to HMCI samples. Finally, in HMC6m samples, stored for 6 months, a significant increase in the levels of $\mathrm{Ca}(-1.965 ; 95 \% \mathrm{CrI}[-3.203 ;-0.770]), \mathrm{Mg}(-0.216 ; 95 \% \mathrm{CrI}[-0.377$; $-0.061]), \mathrm{K}(-130.400$; 95\% CrI [-193.400; -69.810]), and Zn (-26.980; 95\% CrI [-51.910; -2.026]) was observed, compared to HMC3m samples. The mean $\mathrm{Cu}$ levels presented a different pattern in relation to the rest. A significant decrease in $\mathrm{Cu}$ content in the comparison between HMCI and HMC3m and HMCI and HMC6m shows that the storage period reduced the content of this micronutrient.

Table 2. Descriptive statistics of dosage of osmolality and content of macronutrients and micronutrients in HM baseline and the concentrates HMCI, HMC3m, and HMC6m.

\begin{tabular}{|c|c|c|c|c|}
\hline Dosages (units) & HM baseline & HMCI & HMC3m & HMC6m \\
\hline Energy $(\mathrm{Kcal} / 100 \mathrm{~mL})$ & $56.30(10.51)$ & $79.96(13.75)$ & $76.98(13.91)$ & $77.30(13.78)$ \\
\hline Protein $(\mathrm{g} / 100 \mathrm{~mL})$ & $0.90(0.49)$ & $1.48(0.58)$ & $1.39(0.61)$ & $1.47(0.54)$ \\
\hline Carbohydrate $(\mathrm{g} / 100 \mathrm{~mL})$ & $7.08(0.67)$ & $9.18(0.68)$ & $9.21(0.63)$ & $9.18(0.64)$ \\
\hline Total lipids (g/100 mL) & $2.59(1.08)$ & $4.03(1.44)$ & $3.68(1.34)$ & $3.69(1.35)$ \\
\hline Total solids (g/100 mL) & $10.76(1.31)$ & $14.77(1.72)$ & $14.48(1.78)$ & $14.53(1.71)$ \\
\hline True protein $(\mathrm{g} / 100 \mathrm{~mL})$ & $0.75(0.40)$ & $1.20(0.48)$ & $1.13(0.49)$ & $1.19(0.43)$ \\
\hline Osmolality $\left(\mathrm{mOsm} / \mathrm{Kg} \mathrm{H}_{2} 0\right)$ & $289.48(43.64)$ & $452.12(59.79)$ & $456.16(56.58)$ & $458.14(55.67)$ \\
\hline Calcium (mg/100 mL) & $23.24(4.70)$ & $36.52(7.18)$ & $38.67(6.25)$ & $40.63(6.02)$ \\
\hline Magnesium (mEq/L) & $2.14(0.46)$ & $3.38(0.65)$ & $3.52(0.83)$ & $3.73(0.90)$ \\
\hline Sodium (mg/L) & $135.04(98.03)$ & $222.52(169.03)$ & $244.87(162.80)$ & $233.19(141.53)$ \\
\hline Potassium (mg/L) & $601.38(147.98)$ & $1013.85(269.45)$ & $1015.04(222.82)$ & $1152.31(234.18)$ \\
\hline Copper $(\mu \mathrm{g} / 100 \mathrm{~mL})$ & $33.68(14.60)$ & $48.30(19.99)$ & $41.16(15.12)$ & $39.28(13.71)$ \\
\hline $\operatorname{Zinc}(\mu \mathrm{g} / 100 \mathrm{~mL})$ & $149.10(128.15)$ & $203.89(126.20)$ & $224.46(152.50)$ & $251.70(158.76)$ \\
\hline Phosphorus (mg/100 mL) & $14.63(6.09)$ & $18.47(5.97)$ & $20.36(7.52)$ & $20.50(7.35)$ \\
\hline
\end{tabular}

HM baseline: Human milk baseline; HMCI: HM concentrated for immediate analysis; HMC3m: HM concentrate for analysis after 3 months of storage; HMC6m: HM concentrate for analysis after 6 months of storage; Mean (standard deviation).

https://doi.org/10.1371/journal.pone.0210999.t002 
Table 3. Mean difference of dosages of osmolality and content of macronutrients and micronutrients analyzed between HM baseline and concentrates HMCI, HMC3m, and HMC6m.

\begin{tabular}{|c|c|c|c|c|}
\hline Variable & Comparisons & $\begin{array}{c}\text { Mean } \\
\text { difference }\end{array}$ & $\begin{array}{c}\text { 95\% CrI } \\
\text { lower limit }\end{array}$ & $\begin{array}{c}\text { 95\% CrI } \\
\text { upper limit }\end{array}$ \\
\hline \multirow{6}{*}{$\begin{array}{l}\text { Energy } \\
(\mathrm{kcal} / 100 \mathrm{~mL})\end{array}$} & HM baseline-HMCI & -23.680 & -25.910 & -21.450 \\
\hline & HM baseline-HMC3m & -20.690 & -22.930 & -18.410 \\
\hline & HM baseline-HMC6m & -21.000 & -23.240 & -18.750 \\
\hline & HMCI-HMC3m & 2.988 & 0.689 & 5.193 \\
\hline & HMCI-HMC6m & 2.672 & 0.417 & 4.878 \\
\hline & HMC3m - HMC6m & -0.316 & -2.598 & 1.951 \\
\hline \multirow{6}{*}{$\begin{array}{l}\text { Proteins } \\
(\mathrm{g} / 100 \mathrm{~mL})\end{array}$} & HM baseline-HMCI & -0.576 & -0.668 & -0.482 \\
\hline & HM baseline-HMC3m & -0.490 & -0.584 & -0.394 \\
\hline & HM baseline-HMC6m & -0.566 & -0.660 & -0.472 \\
\hline & HMCI-HMC3m & 0.086 & -0.010 & 0.179 \\
\hline & HMCI-HMC6m & 0.010 & -0.086 & 0.105 \\
\hline & HMC3m - HMC6m & -0.076 & -0.174 & 0.018 \\
\hline \multirow{6}{*}{$\begin{array}{l}\text { Carbohydrates } \\
(\mathrm{g} / 100 \mathrm{~mL})\end{array}$} & HM baseline-HMCI & -2.095 & -2.286 & -1.912 \\
\hline & HM baseline-HMC3m & -2.126 & -2.307 & -1.934 \\
\hline & HM baseline-HMC6m & -2.099 & -2.286 & -1.912 \\
\hline & HMCI-HMC3m & -0.030 & -0.220 & 0.151 \\
\hline & HMCI-HMC6m & -0.004 & -0.189 & 0.176 \\
\hline & HMC3m - HMC6m & 0.026 & -0.161 & 0.209 \\
\hline \multirow{6}{*}{$\begin{array}{l}\text { Total lipids } \\
(\mathrm{g} / 100 \mathrm{~mL})\end{array}$} & HM baseline-HMCI & -1.437 & -1.678 & -1.193 \\
\hline & HM baseline-HMC3m & -1.095 & -1.340 & -0.845 \\
\hline & HM baseline-HMC6m & -1.102 & -1.342 & -0.863 \\
\hline & HMCI-HMC3m & 0.342 & 0.099 & 0.591 \\
\hline & HMCI-HMC6m & 0.335 & 0.095 & 0.579 \\
\hline & HMC3m - HMC6m & -0.006 & -0.248 & 0.233 \\
\hline \multirow{6}{*}{$\begin{array}{l}\text { Total solids } \\
(\mathrm{g} / 100 \mathrm{~mL})\end{array}$} & HM baseline-HMCI & -4.004 & -4.307 & -3.703 \\
\hline & HM baseline-HMC3m & -3.715 & -4.020 & -3.406 \\
\hline & HM baseline-HMC6m & -3.769 & -4.072 & -3.463 \\
\hline & HMCI-HMC3m & 0.289 & -0.023 & 0.588 \\
\hline & HMCI-HMC6m & 0.236 & -0.070 & 0.535 \\
\hline & HMC3m - HMC6m & -0.053 & -0.363 & 0.254 \\
\hline \multirow{6}{*}{$\begin{array}{l}\text { True protein } \\
(\mathrm{g} / 100 \mathrm{~mL})\end{array}$} & HM baseline-HMCI & -0.453 & -0.531 & -0.375 \\
\hline & HM baseline-HMC3m & -0.380 & -0.458 & -0.301 \\
\hline & HM baseline-HMC6m & -0.444 & -0.522 & -0.366 \\
\hline & HMCI-HMC3m & 0.072 & -0.008 & 0.149 \\
\hline & HMCI-HMC6m & 0.008 & -0.070 & 0.085 \\
\hline & HMC3m - HMC6m & -0.064 & -0.143 & 0.015 \\
\hline \multirow{6}{*}{$\begin{array}{l}\text { Osmolality } \\
\left(\mathrm{mOsm} / \mathrm{Kg} \mathrm{H}_{2} 0\right)\end{array}$} & HM baseline-HMCI & -162.200 & -177.900 & -146.600 \\
\hline & HM baseline-HMC3m & -166.200 & -182.000 & -150.300 \\
\hline & HM baseline-HMC6m & -168.100 & -183.700 & -152.300 \\
\hline & HMCI-HMC3m & -3.975 & -20.040 & 11.420 \\
\hline & HMCI-HMC6m & -5.920 & -21.630 & 9.556 \\
\hline & HMC3m - HMC6m & -1.945 & -17.880 & 13.980 \\
\hline
\end{tabular}


Table 3. (Continued)

\begin{tabular}{|c|c|c|c|c|}
\hline Variable & Comparisons & $\begin{array}{c}\text { Mean } \\
\text { difference }\end{array}$ & $\begin{array}{c}\text { 95\% CrI } \\
\text { lower limit }\end{array}$ & $\begin{array}{c}\text { 95\% CrI } \\
\text { upper limit }\end{array}$ \\
\hline \multirow{6}{*}{$\begin{array}{l}\text { Calcium } \\
(\mathrm{mg} / 100 \mathrm{~mL})\end{array}$} & HM baseline-HMCI & -13.290 & -14.460 & -12.100 \\
\hline & HM baseline-HMC $3 \mathrm{~m}$ & -15.420 & -16.620 & -14.210 \\
\hline & HM baseline-HMC6m & -17.390 & -18.580 & -16.200 \\
\hline & HMCI-HMC3m & -2.139 & -3.356 & -0.971 \\
\hline & HMCI-HMC6m & -4.103 & -5.325 & -2.904 \\
\hline & HMC3m - HMC6m & -1.965 & -3.203 & -0.770 \\
\hline \multirow{6}{*}{$\begin{array}{l}\text { Magnesium } \\
(\mathrm{mEq} / \mathrm{L})\end{array}$} & HM baseline-HMCI & -1.234 & -1.386 & -1.080 \\
\hline & HM baseline-HMC3m & -1.376 & -1.532 & -1.219 \\
\hline & HM baseline-HMC6m & -1.591 & -1.747 & -1.437 \\
\hline & HMCI-HMC3m & -0.141 & -0.298 & 0.010 \\
\hline & HMCI-HMC6m & -0.357 & -0.515 & -0.201 \\
\hline & HMC3m - HMC6m & -0.216 & -0.377 & -0.061 \\
\hline \multirow{6}{*}{$\begin{array}{l}\text { Sodium } \\
(\mathrm{mg} / \mathrm{L})\end{array}$} & HM baseline-HMCI & -86.600 & -113.500 & -58.860 \\
\hline & HM baseline-HMC3m & -108.600 & -136.600 & -80.480 \\
\hline & HM baseline-HMC6m & -97.060 & -124.900 & -69.270 \\
\hline & HMCI-HMC3m & -22.020 & -50.450 & 5.252 \\
\hline & HMCI-HMC6m & -10.460 & -38.880 & 17.470 \\
\hline & HMC3m - HMC6m & 11.570 & -17.490 & 39.240 \\
\hline \multirow{6}{*}{$\begin{array}{l}\text { Potassium } \\
(\mathrm{mg} / \mathrm{L})\end{array}$} & HM baseline-HMCI & -392.100 & -451.100 & -331.600 \\
\hline & HM baseline-HMC3m & -393.000 & -453.600 & -330.500 \\
\hline & HM baseline-HMC6m & -523.400 & -584.100 & -462.800 \\
\hline & HMCI-HMC3m & -0.929 & -62.620 & 58.190 \\
\hline & HMCI-HMC6m & -131.400 & -193.500 & -70.690 \\
\hline & HMC3m - HMC6m & -130.400 & -193.400 & -69.810 \\
\hline \multirow{6}{*}{$\begin{array}{l}\text { Copper } \\
(\mu \mathrm{g} / 100 \mathrm{~mL})\end{array}$} & HM baseline-HMCI & -14.950 & -18.200 & -11.740 \\
\hline & HM baseline-HMC3m & -7.799 & -11.040 & -4.511 \\
\hline & HM baseline-HMC6m & -5.914 & -9.141 & -2.656 \\
\hline & HMCI-HMC3m & 7.154 & 3.840 & 10.330 \\
\hline & HMCI-HMC6m & 9.040 & 5.782 & 12.230 \\
\hline & HMC3m - HMC6m & 1.885 & -1.388 & 5.166 \\
\hline \multirow{6}{*}{$\begin{array}{l}\text { Zinc } \\
(\mu \mathrm{g} / 100 \mathrm{~mL})\end{array}$} & HM baseline-HMCI & -54.530 & -79.040 & -30.160 \\
\hline & HM baseline-HMC3m & -74.840 & -99.420 & -49.910 \\
\hline & HM baseline-HMC6m & -101.800 & -126.400 & -77.040 \\
\hline & HMCI-HMC3m & -20.320 & -45.420 & 3.872 \\
\hline & HMCI-HMC6m & -47.290 & -72.040 & -23.100 \\
\hline & HMC3m - HMC6m & -26.980 & -51.910 & -2.026 \\
\hline \multirow{6}{*}{$\begin{array}{l}\text { Phosphorus } \\
\text { (mg/100 mL) }\end{array}$} & HM baseline-HMCI & -3.859 & -5.557 & -2.176 \\
\hline & HM baseline-HMC3m & -5.741 & -7.437 & -4.020 \\
\hline & HM baseline-HMC6m & -5.881 & -7.575 & -4.175 \\
\hline & HMCI-HMC3m & -1.882 & -3.618 & -0.209 \\
\hline & HMCI-HMC6m & -2.022 & -3.738 & -0.355 \\
\hline & HMC3m - HMC6m & -0.140 & -1.865 & 1.570 \\
\hline
\end{tabular}

HM baseline: Human milk baseline; HMCI: HM concentrated for immediate analysis; HMC3m: HM concentrate for analysis after 3 months of storage; HMC6m: HM concentrate for analysis after 6 months of storage. 95\% CrI: Credibility interval 95\%.

https://doi.org/10.1371/journal.pone.0210999.t003 


\section{Discussion}

Considering the current need for the fortification of HM used in the nutritional support of VLBW infants, this study presents an innovative possibility of formulating a concentrated HM through a simplified method of direct lyophilization of milk donated to HMB. Thus, the merit of this study was to demonstrate the possibility of formulating a product with high nutritional quality components with low cost of production and without ethical bias.

Several authors emphasize the necessary addition of fortifiers to banked human milk in order to increase the nutrient content and thus to be able to meet the special nutritional needs of VLBW infants [2-4]. In the neonatal clinical practice of most public hospitals in Brazil, bovine milk protein-based products such as FM-85 (Nestlé) and Enfamil HMF (Mead Johnson) are used as fortifiers. However, studies report that such products delay gastric emptying and expose preterm infants to the risk of sensitization by heterologous protein and the occurrence of NEC [35-38].

The present study introduces an innovative proposal for the formulation of a human milkbase additive through a simplified direct freeze-drying method followed by a single pasteurization process, which minimizes the risk of contamination and nutrient loss. A similar study carried out in Brazil reports on the development of two human milk-based additives (liquid and powdered) from fat extraction, evaporation, lactose reduction, and lyophilization methods [37]. That same research group has recently improved the formulation method of the powder additive by minimizing the risks of the elaboration and handling processes of HM by simplifying the method to lactose reduction and lyophilization alone. The partial removal of lactose is justified by the control of osmolality of HM strengthened with the powdered additive, which increases tolerance by preterm infants, minimizing the risk of NEC [39-40]. In the present study, the proposed simplified method consists of lyophilization without lactose reduction, and it is important to highlight that the concentrated HM after the addition of the lyophilizate maintained an acceptable osmolality according to the values tolerated by VLBW infants.

The control of osmolality and the physical-chemical and microbiological qualities of HM is essential for its safe provision to VLBW infants. Recent studies show that the procedures carried out in this study, which were established as a protocol by the HMB Network in Brazil, do not change the osmolality or the levels of macronutrients and micronutrients in the milk $[31,34,41]$. In terms of the lyophilization process, studies report that lyophilizing HM before the freezing process allows for a better preservation of the nutritional properties of milk [4243]. In this study, the presented values of osmolality and the levels of macronutrients and micronutrients refer to the moment post-lyophilization and pasteurization; therefore, they reflect the final composition of concentrated HM.

The concentrated milk produced in this study is a safe and viable nutritional support alternative since it presents acceptable osmolality and meets the nutritional needs of VLBW infants related to the recommended enteral intake of macronutrients and micronutrients, with few exceptions, and may allow for a reduction in the use of bovine milk protein-based additives. Consensus-based evidence regarding the optimization of nutritional support of VLBW infant reports that the first choice of enteral feeding is own mother's milk fortified with balanced osmolality to ensure safe supply of additional nutrients $[4,15]$. Studies show that osmolality of a preterm mother's milk is similar to our HM baseline, mature milk donated by "term" mothers in the later stage of lactation, and this allows our lyophilizate to be used as an additive to the milk of the VLBW infant's own mother, thus generating a concentrate with acceptable osmolality $[22,40]$.

Regarding the recommendations of macronutrients and micronutrients expressed per 100 kcal of HMCI presented in S1 Table, the mean and confidence interval (CI) of protein (1.85g; 
90\% CI [1.68-2.02]), Ca (45.70mg; 90\% CI [43.56-47.81]), Mg (5.13mg; 90\% CI [4.89-5.36]), $\mathrm{Na}$ (27.84mg; 90\% CI [22.84-32.83)], Cu (60.42 $\mu$ g; 90\% CI [54.51-66.33]), Zn (0.25mg; 90\% CI [0.22-0.29)], and P (23.10mg; 90\% CI [21.34-24.87]) content partially meet the recommendations of enteral intakes established by the Life Sciences Research Office (LRSO 2002) and the European Society of Pediatric Gastroenterology, Hepatology, and Nutrition (ESPGHAN 2010) for preterm infants. It is important to emphasize that the content of carbohydrate $(11.48 \mathrm{~g} ; 90 \%$ CI [11.28-11.68]), total lipids (5.04g; 90\% CI [4.61-5.46]), and K (126.83mg; 90\% CI [118.87134.79]), expressed per $100 \mathrm{kcal}$ of HMCI (S1 Table) fully meet the established recommendations cited above [44-45].

The evolution of neonatal nutritional protocols over the years shows an improvement in the intake of energy and macronutrients through HM and, consequently, better neonatal growth and neurodevelopment [46-47]. Thus, given the updated literature cited and the adequacy of our concentrate on the recommendations of enteral intakes of LRSO 2002 and ESPGHAN 2010, the protein content of our concentrate could raise concerns. However, studies suggest that the quality of human milk protein and the adequate balance of energy and protein intake are associated advantages in rate and quality of growth as well as better clinical outcomes for VLBW infants $[18,48-51]$. Thus, we believe that our HM concentrate allows an optimization of the nutritional support of premature babies, as it guarantees the supply of high quality bioactive proteins and adequate content of carbohydrates, lipids and $\mathrm{K}$.

The contents of $\mathrm{Ca}, \mathrm{Mg}, \mathrm{Na}, \mathrm{Cu}, \mathrm{Zn}$, and $\mathrm{P}$ in the concentrated HM sample types also deserve special attention. According to the recommendations of LRSO 2002 and ESPGHAN 2010, these elements may merit isolated supplementation [44-45]. In addition, adequate early intake of protein and energy in the first week of life of VLBW infants improves the homeostasis of the electrolytes in question [52]. Preterm infants require high amounts of $\mathrm{Ca}$ and $\mathrm{P}$ elements and, due to low skeletal storages, are at increased risk of nutritional disorders such as growth and developmental deficits, hypophosphatemia, osteopenia in prematurity, and metabolic bone disease [53-54].

The essential micronutrients $\mathrm{Mg}, \mathrm{Zn}$ and $\mathrm{Cu}$ are also related to child growth and development as well as immune function [55-57]. A retrospective study confirmed the association between serum levels of $\mathrm{Cu}$ and $\mathrm{Zn}$, gestational age and anthropometric parameters of body weight, and body length and head circumference at birth in preterm infants [57]. Watson et al. warned that the most common cause of Zn deficiency is dietary because of the low micronutrient supply that can be generated by the intake of inadequate milk volumes and non-fortified HM [58]. In addition, Cu deficiency is also recurrent in VLBW infants and can cause anemia, neutropenia, failure to thrive, psychomotor retardation, and bone abnormalities [59]. In addition, it is important to note that chronic depletion of $\mathrm{Na}$ also negatively affects weight gain and the growth of preterm infants, especially VLBW infants, since they present higher losses of $\mathrm{Na}$ and thus require supplementation [60-61]. Therefore, considering the decision to use the HM concentrate produced in this study as a nutritional support strategy for VLBW infants, it will be necessary to monitor and eventually supplement as needed the serum levels of $\mathrm{Ca}, \mathrm{Mg}, \mathrm{Na}$, $\mathrm{Cu}, \mathrm{Zn}$, and $\mathrm{P}$.

The content of macronutrients and micronutrients as well as the osmolality of our concentrated HM has similarities to some currently marketed breast milk fortifiers. The human milkbased additive Prolact +4 H2MF (Prolacta Bioscience) when added to $80 \mathrm{~mL}$ of preterm mother's milk reaches an energy content of $82 \mathrm{kcal}$ per $100 \mathrm{~mL}$, according to the information provided by the manufacturer, which is similar to our HMCI as shown in Table 2. However, while our product is able to provide higher amounts of carbohydrates and total lipids per 100 $\mathrm{mL}$ (Table 2), Prolacta $+4 \mathrm{H} 2 \mathrm{MF}$ provides greater amounts of protein $(2.3 \mathrm{~g}), \mathrm{Na}(57 \mathrm{mg}), \mathrm{Ca}$ (123 mg), Zn (0.97 mg), and P (64 mg). Despite this, a recent study warned that HM fortified 
with human milk-based additive does not meet the nutritional recommendations for VLBW infants established by the American Academy of Pediatrics Committee of Nutrition because the supply of protein and vitamins is insufficient when it reaches the recommended caloric intake of $130 \mathrm{kcal} / \mathrm{kg}$ [62].

In Brazilian public hospitals, one of the most used HM fortifiers is FM-85 (Nestlé). According to the manufacturer's information, such a bovine milk protein-based additives when added to the HM $(100 \mathrm{~mL})$ of the premature mother provides: $85 \mathrm{kcal}, 2.5 \mathrm{~g}$ of protein, $10.3 \mathrm{~g}$ of carbohydrates, $4.02 \mathrm{~g}$ of total lipids, $100 \mathrm{mg}$ of Ca, and $59 \mathrm{mg}$ of P. Comparing this nutritional information with the composition of our HMCI (Table 2), we observed similar levels of energy content, protein, and carbohydrates. However, the content of $\mathrm{Ca}$ and $\mathrm{P}$ present in 100 $\mathrm{mL}$ of HMCI is lower than that offered by HM fortified with FM-85 (Nestlé) [22].

Some authors suggest that the use of the FM- 85 additive (Nestlé) improves the bone mineralization of VLBW infants, although others report the negative effects of its use $[35,36,63]$. Sullivan et al. found that the nutritional support of VLBW infants using human milk-based fortifier was associated with lower occurrence of NEC or death when compared to the use of bovine milk protein-based additives [35]. This fact is justified by LH allowing the maternal transfer of adaptive immune defenses, especially secretory IgA, which presents in higher concentration in the maternal milk of mothers of preterm infants [64].

The preservation of nutritional and immunological components as well as the safety of HM processed in HMB is a concern addressed in current literature reviews, as studies and proposals to improve milk manipulation protocols are constantly being generated [32,65]. A study conducted by Ahrabi et al. showed that the process of refrigeration at $+4^{\circ} \mathrm{C}$ for 72 hours followed by frozen storage at $-20^{\circ} \mathrm{C}$ for up to 9 months applied to freshly expressed $\mathrm{HM}$ was associated with decreased $\mathrm{pH}$ and bacterial counts without affecting the content of total protein, fat, lactoferrin, secretory IgA, and osmolarity in the samples [66]. However, Sousa et al. proved that pasteurization of $\mathrm{HM}$ colostrum caused a reduction of 20,51 , and $23 \%$ in $\operatorname{IgA}, \operatorname{IgM}$, and IgG concentrations, respectively [67]. A literature review concluded a similar reduction of IgA, IgM, and IgG concentrations in HM after holder pasteurization; however, the authors warn that clinical practice demonstrates that many beneficial properties remain after pasteurization, which strongly justifies the use of HM processed in HMB for feeding preterm infants [34]. Therefore, our proposal for the nutritional support of VLBW infants with concentrated HM is also strengthened.

The present study generated a new hypothesis which will be elucidated in future studies: the possibility of adding lyophilized HM directly into the mother's own raw milk to produce an improved concentrated milk. A systematic review presents the differences between nutrient contents according to gestational stage (preterm versus term) and lactation time, emphasizing that the colostrum of mothers of preterm infants presented a higher protein mean when compared with mature HM [68]. Thus, it is likely that our lyophilized milk $(50 \mathrm{~mL}$ matured donated milk) when added to a VLBW infant's mother's own raw milk will produce a concentrated HM with a higher protein content and adequate osmolality that can meet the nutritional needs of preterm infants $[37,44,68]$. Other authors reinforce the initiative to use the mother's own raw milk during the hospitalization period of preterm infants. Dritsakou et al. suggested that feeding VLBW infants predominantly with the mother's own raw milk results in better neonatal outcomes such as higher body length and head circumference at discharge [69]. In addition, a prospective cohort study conducted with VLBW infants fed exclusively with HM demonstrated an association between the early use of the mother's own raw milk and continued breastfeeding at discharge (OR 2.92; 95\% CI [1.94-4.40]), and after 6 months (OR 2.70; 95\% CI [1.21-6.03]) [70]. 
In view of all the arguments presented, the concentrated HM produced in this study is an innovative, viable, and less onerous proposal after initial investment, which can provide many benefits to VLBW infants as well as national and international health systems. Finally, the last aim of this study was to evaluate the stability of the concentrated HM samples stored for 3 and 6 months. After 3 months of storage, comparing samples of HMCI and HM3m, the Ca and P contents increased and the levels of energy, total lipids, and $\mathrm{Cu}$ were reduced. However, comparing samples of $\mathrm{HMCI}$ and $\mathrm{HM} 6 \mathrm{~m}$, a significant increase in the levels of $\mathrm{Ca}, \mathrm{Mg}, \mathrm{K}, \mathrm{Zn}$, and $\mathrm{P}$ was observed, despite a slight reduction in levels of energy and total lipids, while the osmolality and other nutrients remained stable, except for $\mathrm{Cu}$. The $\mathrm{Cu}$ content presented a different pattern in relation to the rest, since it was the only one that suffered a high reduction after the storage period. Despite significant changes in the nutritional content of concentrated HM stored for 3 and 6 months, we considered clinically relevant only the increase of $\mathrm{K}$ and the reduction of $\mathrm{Cu}$ in the samples. In view of these results, it is possible to preserve the concentrated HM for 6 months; however, it is necessary to consider the changes in the nutritional content of this product, mainly in the $\mathrm{K}$ and $\mathrm{Cu}$ elements, which suggest the non-storage of this concentrated product. Currently, target fortification has been tested as a method for adjusting macronutrient and micronutrient content in fortified HM with marketed products that even after fortification may not fully meet the nutritional needs of VLBW infants, unlike the concentrated HM produced in this study [71-72]. Several authors suggest that target fortification is safe and capable of individually optimizing the intake of macronutrients (protein, carbohydrate, and fat) by VLBW infants according to the ESPGHAN 2010 guidelines [73-74]. One limitation of this study was the lack of evaluation of diet composition of the donors during the pre-gestational, gestational, and post -gestational periods.

\section{Conclusions}

The present study confirms the possibility of formulating concentrated HM, generated from the freeze-drying of the milk donated from the HMB, with osmolality and levels of certain macronutrients and micronutrients compatible with the nutritional needs of VLBW infants. It should be noted that the simplified direct lyophilization method for the formulation of our concentrated HM minimizes the risk of contamination due to minimum product handling as well as present low cost after an initial investment and does not characterize ethical bias since the milk was donated. In addition, the HM samples stored for 3 and 6 months were evaluated and their osmolality stability and nutrient content stability were verified, with both increases and reductions of certain nutrients, such as $\mathrm{K}$ and $\mathrm{Cu}$. Another issue to be considered is the promising possibility of HM conservation through the freeze-drying process of donated milk. The present authors are committed to future research looking forward to a randomized controlled double blind clinical trial, phase 1 and 2, whose financial support was recently approved by the Brazilian CNPq (National Council for Scientific and Technological Development), in order to evaluate the safety and tolerability, as well as the initial performance of our HM concentrate to be used as a resource for the nutritional support of VLBW infants.

\section{Supporting information}

S1 Fig. Boxplot of the descriptive results of osmolality, macronutrients, and micronutrients in samples of types HM baseline, HMCI, HMC3m, and HMC6m.

S1 Table. Mean and confidence interval $90 \%$ for osmolality, macronutrients, and micronutrients expressed per $100 \mathrm{kcal}$ in the samples of types HM baseline, HMCI, HMC3m, and 
HMC6m.

(PDF)

S1 Dataset. Database collected available.

(XLSX)

S2 Dataset. Descriptive statistic of macronutrients.

(PDF)

S3 Dataset. Descriptive statistic of micronutrients.

(PDF)

\section{Author Contributions}

Conceptualization: Anália R. Heck, Francisco E. Martinez, José S. Camelo, Jr.

Data curation: Mariana M. Oliveira, Davi C. Aragon, Vanessa S. Bomfim, Tânia M. B. Trevilato, Larissa G. Alves, Anália R. Heck, José S. Camelo, Jr.

Formal analysis: Mariana M. Oliveira, Davi C. Aragon, Tânia M. B. Trevilato, Larissa G. Alves, Francisco E. Martinez, José S. Camelo, Jr.

Funding acquisition: José S. Camelo, Jr.

Investigation: Mariana M. Oliveira, Tânia M. B. Trevilato, Anália R. Heck, Francisco E. Martinez, José S. Camelo, Jr.

Methodology: Mariana M. Oliveira, Davi C. Aragon, Vanessa S. Bomfim, Tânia M. B. Trevilato, Larissa G. Alves, Francisco E. Martinez, José S. Camelo, Jr.

Project administration: José S. Camelo, Jr.

Resources: Tânia M. B. Trevilato, Larissa G. Alves.

Software: Davi C. Aragon.

Supervision: Larissa G. Alves, José S. Camelo, Jr.

Validation: Tânia M. B. Trevilato, José S. Camelo, Jr.

Visualization: Davi C. Aragon.

Writing - original draft: Mariana M. Oliveira, José S. Camelo, Jr.

\section{References}

1. McNelis K, Fu TT, Poindexter B. Nutrition for the extremely preterm infant. Clin Perinatol. 2017 Jun; 44 (2):395-406. https://doi.org/10.1016/j.clp.2017.01.012 PMID: 28477668

2. Harding JE, Cormack BE, Alexander T, Alsweiler JM, Bloomfield FH. Advances in nutrition of the newborn infant. Lancet. 2017 Apr 22; 389(10079):1660-1668. https://doi.org/10.1016/S0140-6736(17) 30552-4 PMID: 28443560

3. Raiten DJ, Steiber AL, Hand RK. Executive summary: evaluation of the evidence to support practice guidelines for nutritional care of preterm infants-the Pre-B Project. Am J Clin Nutr. 2016 Feb; 103 (2):599S-605S. https://doi.org/10.3945/ajcn.115.124222 PMID: 26791179

4. Kumar RK, Singhal A, Vaidya U, Banerjee S, Anwar F, Rao S. Optimizing nutrition in preterm low birth weight infants-consensus summary. Front Nutr. 2017 May 26; 4:20. https://doi.org/10.3389/fnut.2017. 00020 PMID: 28603716

5. Stephens BE, Walden RV, Gargus RA, Tucker R, McKinley L, Mance M, et al. First-week protein and energy intakes are associated with 18-month developmental outcomes in extremely low birth weight infants. Pediatrics. 2009 May; 123(5):1337-43. https://doi.org/10.1542/peds.2008-0211 PMID: 19403500 
6. Hiltunen $\mathrm{H}$, Löyttyniemi $\mathrm{E}$, Isolauri $\mathrm{E}$, Rautava $\mathrm{S}$. Early nutrition and growth until the corrected age of 2 years in extremely preterm infants. Neonatology. 2018; 113(2):100-107. https://doi.org/10.1159/ 000480633 PMID: 29131014

7. Andreas NJ, Kampmann B, Mehring Le-Doare K. Human breast milk: A review on its composition and bioactivity. Early Hum Dev. 2015 Nov; 91(11):629-35. https://doi.org/10.1016/j.earlhumdev.2015.08. 013 PMID: 26375355

8. Walker A. Breast milk as the gold standard for protective nutrients. J Pediatr. 2010 Feb; 156(2 Suppl): S3-7. https://doi.org/10.1016/j.jpeds.2009.11.021 PMID: 20105662

9. Sammallahti S, Kajantie E, Matinolli HM, Pyhälä R, Lahti J, Heinonen K, et al. Nutrition after preterm birth and adult neurocognitive outcomes. PLoS One. 2017 Sep 28; 12(9):e0185632. https://doi.org/10. 1371/journal.pone.0185632 PMID: 28957424

10. Patra K, Hamilton M, Johnson TJ, Greene M, Dabrowski E, Meier PP, et al. NICU human milk dose and 20-Month neurodevelopmental outcome in very low birth weight infants. Neonatology. 2017; 112 (4):330-336. https://doi.org/10.1159/000475834 PMID: 28768286

11. Cortez J, Makker K, Kraemer DF, Neu J, Sharma R, Hudak ML. Maternal milk feedings reduce sepsis, necrotizing enterocolitis and improve outcomes of premature infants. J Perinatol. $2018 \mathrm{Jan}$; 38(1):7174. https://doi.org/10.1038/jp.2017.149 PMID: 29048409

12. Colaizy TT, Bartick MC, Jegier BJ, Green BD, Reinhold AG, Schaefer AJ, et al. Impact of optimized breastfeeding on the costs of necrotizing enterocolitis in extremely low birthweight infants. J Pediatr. 2016 Aug; 175:100-105.e2. https://doi.org/10.1016/j.jpeds.2016.03.040 PMID: 27131403

13. Assad M, Elliott MJ, Abraham JH. Decreased cost and improved feeding tolerance in VLBW infants fed an exclusive human milk diet. J Perinatol. 2016 Mar; 36(3):216-20. https://doi.org/10.1038/jp.2015.168 PMID: 26562370

14. Dutta S, Singh B, Chessell L, Wilson J, Janes M, McDonald K, et al. Guidelines for feeding very low birth weight infants. Nutrients. 2015 Jan 8; 7(1):423-42. https://doi.org/10.3390/nu7010423 PMID: 25580815

15. Bertino E, Giuliani F, Baricco M, Di Nicola P, Peila C, Vassia C, et al. Benefits of donor milk in the feeding of preterm infants. Early Hum Dev. 2013 Oct; 89 Suppl 2:S3-6.

16. Valentine CJ, Morrow G, Reisinger A, Dingess KA, Morrow AL, Rogers LK. Lactational stage of pasteurized human donor milk contributes to nutrient limitations for infants. Nutrients. 2017 Mar 18; 9(3). pii: E302. https://doi.org/10.3390/nu9030302 PMID: 28335478

17. Colaizy TT, Carlson S, Saftlas AF, Morriss FH Jr. Growth in VLBW infants fed predominantly fortified maternal and donor human milk diets: a retrospective cohort study. BMC Pediatr. 2012 Aug 17; 12:124. https://doi.org/10.1186/1471-2431-12-124 PMID: 22900590

18. Morlacchi L, Roggero $P$, Giannì ML, Bracco B, Porri $D$, Battiato $E$, et al. Protein use and weight-gain quality in very-low-birth-weight preterm infants fed human milk or formula. Am J Clin Nutr. 2018 Feb 1; 107(2):195-200. https://doi.org/10.1093/ajcn/nqx001 PMID: 29529139

19. Bhatia J, Griffin I, Anderson D, Kler N, Domellöf M. Selected macro/micronutrient needs of the routine preterm infant. J Pediatr. 2013 Mar; 162(3 Suppl):S48-55. https://doi.org/10.1016/j.jpeds.2012.11.053 PMID: 23445848

20. Terrin G, Berni Canani R, Di Chiara M, Pietravalle A, Aleandri V, Conte F, et al. Zinc in Early Life: A Key Element in the fetus and preterm neonate. Nutrients. 2015 Dec 11; 7(12):10427-46. https://doi.org/10. 3390/nu7125542 PMID: 26690476

21. Abiramalatha $T$, Thomas N, Gupta V, Viswanathan A, McGuire W. High versus standard volume enteral feeds to promote growth in preterm or low birth weight infants. Cochrane Database Syst Rev. 2017 Sep 12; 9:CD012413. https://doi.org/10.1002/14651858.CD012413.pub2 PMID: 28898404

22. Kreissl A, Zwiauer V, Repa A, Binder C, Haninger N, Jilma B, et al. Effect of fortifiers and additional protein on the osmolarity of human milk: is it still safe for the premature infant? J Pediatr Gastroenterol Nutr. 2013 Oct; 57(4):432-7. https://doi.org/10.1097/MPG.0b013e3182a208c7 PMID: 23857340

23. Abrams SA, Schanler RJ, Lee ML, Rechtman DJ. Greater mortality and morbidity in extremely preterm infants fed a diet containing cow milk protein products. Breastfeed Med. 2014 Jul-Aug; 9(6):281-5. https://doi.org/10.1089/bfm.2014.0024 PMID: 24867268

24. Hair AB, Peluso AM, Hawthorne KM, Perez J, Smith DP, Khan JY, et al. Beyond necrotizing enterocolitis prevention: Improving outcomes with an exclusive human milk-based diet. Breastfeed Med. 2016 Mar; 11(2):70-4. https://doi.org/10.1089/bfm.2015.0134 PMID: 26789484

25. Brown JV, Embleton ND, Harding JE, McGuire W. Multi-nutrient fortification of human milk for preterm infants. Cochrane Database Syst Rev. 2016 May 8;(5):CD000343. https://doi.org/10.1002/14651858. CD000343.pub3 PMID: 27155888 
26. Hair AB, Blanco CL, Moreira AG, Hawthorne KM, Lee ML, Rechtman DJ, et al. Randomized trial of human milk cream as a supplement to standard fortification of an exclusive human milk-based diet in infants 750-1250 g birth weight. J Pediatr. 2014 Nov; 165(5):915-20. https://doi.org/10.1016/j.jpeds. 2014.07.005 PMID: 25130571

27. Ganapathy V, Hay JW, Kim JH. Costs of necrotizing enterocolitis and cost-effectiveness of exclusively human milk-based products in feeding extremely premature infants. Breastfeed Med. 2012 Feb; 7 (1):29-37. https://doi.org/10.1089/bfm.2011.0002 PMID: 21718117

28. Carroll K, Herrmann KR. The cost of using donor human milk in the NICU to achieve exclusively human milk feeding through 32 weeks postmenstrual age. Breastfeed Med. 2013 Jun; 8(3): 286-90. https://doi. org/10.1089/bfm.2012.0068 PMID: 23323965

29. Hair AB, Bergner EM, Lee ML, Moreira AG, Hawthorne KM, Rechtman DJ, et al. Premature infants 750-1,250 g birth weight supplemented with a novel human milk-derived cream are discharged sooner. Breastfeed Med. 2016 Apr; 11:133-7. https://doi.org/10.1089/bfm.2015.0166 PMID: 26982282

30. Escuder-Vieco D, Vázquez-Román S, Sánchez-Pallás J, Ureta-Velasco N, Mosqueda-Peña R, PallásAlonso CR. Determination of acidity in donor milk. J Hum Lact. 2016 Nov; 32(4):NP73-NP75. https:// doi.org/10.1177/0890334415591338 PMID: 26116636

31. Grazziotin MC, Grazziotin AL, Vidal NM, Freire MH, da Silva RP. Analysis of the storage methods for raw human milk from mothers with infants admitted to a neonatal intensive care unit, according to Brazilian Regulations. J Hum Lact. 2016 Aug; 32(3):446-54. https://doi.org/10.1177/0890334416647710 PMID: 27165765

32. Picaud JC, Buffin R. Human milk-treatment and quality of banked human milk. Clin Perinatol. 2017 Mar; 44(1):95-119. https://doi.org/10.1016/j.clp.2016.11.003 PMID: 28159212

33. Haiden N, Ziegler EE. Human milk banking. Ann Nutr Metab. 2016; 69 Suppl 2:8-15. https://doi.org/10. 1159/000452821

34. Peila C, Moro GE, Bertino E, Cavallarin L, Giribaldi M, Giuliani F, et al. The Effect of holder pasteurization on nutrients and biologically active components in donor human milk: A review. Nutrients. 2016 Aug 2; 8(8). pii: E477. https://doi.org/10.3390/nu8080477 PMID: 27490567

35. Sullivan S, Schanler RJ, Kim JH, Patel AL, Trawöger R, Kiechl-Kohlendorfer U, et al. An exclusively human milk-based diet is associated with a lower rate of necrotizing enterocolitis than a diet of human milk and bovine milk-based products. J Pediatr. 2010 Apr; 156(4):562-7. https://doi.org/10.1016/j. jpeds.2009.10.040 PMID: 20036378

36. Perrella SL, Hepworth AR, Simmer KN, Geddes DT. Influences of breast milk composition on gastric emptying in preterm infants. J Pediatr Gastroenterol Nutr. $2015 \mathrm{Feb} ; 60(2): 264-71$. https://doi.org/10. 1097/MPG.0000000000000596 PMID: 25313848

37. Thomaz DM, Serafim PO, Palhares DB, Melnikov P, Venhofen L, Vargas MO. Comparison between homologous human milk supplements and a commercial supplement for very low birth weight infants. $J$ Pediatr (Rio J). 2012 Mar-Apr; 88(2):119-24.

38. Shulhan J, Dicken B, Hartling L, Larsen BM. Current knowledge of necrotizing enterocolitis in preterm infants and the impact of different types of enteral nutrition products. Adv Nutr. 2017 Jan 17; 8(1):8091. https://doi.org/10.3945/an.116.013193 PMID: 28096129

39. Grance TR, Serafin Pde O, Thomaz DM, Palhares DB. Homologous human milk supplement for very low birth weight preterm infant feeding. Rev Paul Pediatr. 2015 Jan-Mar; 33(1):28-33. https://doi.org/ 10.1016/j.rpped.2014.07.001 PMID: 25662564

40. Rosas R, Sanz MP, Fernández-Calle P, Alcaide MJ, Montes MT, Pastrana N, et al. Experimental study showed that adding fortifier and extra-hydrolysed proteins to preterm infant mothers' milk increased osmolality. Acta Paediatr. 2016 Dec; 105(12):e555-e560. https://doi.org/10.1111/apa.13522 PMID: 27392326

41. Mohd-Taufek N, Cartwright D, Davies M, Hewavitharana AK, Koorts $P$, McConachy H, et al. The effect of pasteurization on trace elements in donor breast milk. J Perinatol. 2016 Oct; 36(10):897-900. https:// doi.org/10.1038/jp.2016.88 PMID: 27253894

42. Lozano B, Castellote Al, Montes R, López-Sabater MC. Vitamins, fatty acids, and antioxidant capacity stability during storage of freeze-dried human milk. Int J Food Sci Nutr. 2014 Sep; 65(6):703-7. https:// doi.org/10.3109/09637486.2014.917154 PMID: 24840090

43. Cortez MV, Soria EA. The effect of freeze-drying on the nutrient, polyphenol, and oxidant levels of breast milk. Breastfeed Med. 2016 Dec; 11:551-554. https://doi.org/10.1089/bfm.2016.0102 PMID: 27925493

44. Tudehope D, Fewtrell M, Kashyap S, Udaeta E. Nutritional needs of the micropreterm infant. J Pediatr. 2013 Mar; 162(3 Suppl):S72-80. https://doi.org/10.1016/j.jpeds.2012.11.056 PMID: 23445852 
45. Agostoni C, Buonocore G, Carnielli VP, De Curtis M, Darmaun D, Decsi T, et al. Enteral nutrient supply for preterm infants: commentary from the European Society of Paediatric Gastroenterology, Hepatology and Nutrition Committee on Nutrition. J Pediatr Gastroenterol Nutr. 2010 Jan; 50(1):85-91. https://doi. org/10.1097/MPG.0b013e3181adaee0 PMID: 19881390

46. Westin V, Klevebro S, Domellöf M, Vanpée M, Hallberg B, Stoltz Sjöström E. Improved nutrition for extremely preterm infants-A population based observational study. Clin Nutr ESPEN. 2018 Feb; 23:245-251. https://doi.org/10.1016/j.clnesp.2017.09.004 PMID: 29460807

47. Schneider J, Fischer Fumeaux CJ, Duerden EG, Guo T, Foong J, Graz MB, et al. Nutrient intake in the first two weeks of life and brain growth in preterm neonates. Pediatrics. 2018; 141(3):e20172169. https://doi.org/10.1542/peds.2017-2169 PMID: 29440285

48. Spiegler J, Preuß M, Gebauer C, Bendiks M, Herting E, Göpel W, et al. Does breastmilk influence the development of bronchopulmonary Dysplasia? J Pediatr. 2016 Feb; 169:76-80.e4. https://doi.org/10. 1016/j.jpeds.2015.10.080 PMID: 26621048

49. Lewis ED, Richard C, Larsen BM, Field CJ. The importance of human milk for immunity in preterm infants. Clin Perinatol. 2017 Mar; 44(1):23-47. https://doi.org/10.1016/j.clp.2016.11.008 PMID: 28159208

50. Lönnerdal B. Bioactive proteins in human milk-potential benefits for preterm infants. Clin Perinatol. 2017 Mar; 44(1):179-191. https://doi.org/10.1016/j.clp.2016.11.013 PMID: 28159205

51. Koletzko B. Should women providing milk to their preterm infants take Docosahexaenoic acid supplements? Clin Perinatol. 2017 Mar; 44(1):85-93. https://doi.org/10.1016/j.clp.2016.11.002 PMID: 28159211

52. Senterre T, Abu Zahirah I, Pieltain C, de Halleux V, Rigo J. Electrolyte and mineral homeostasis after optimizing early macronutrient intakes in VLBW infants on parenteral nutrition. J Pediatr Gastroenterol Nutr. 2015 Oct; 61(4):491-8. https://doi.org/10.1097/MPG.0000000000000854 PMID: 25988555

53. Körnmann MN, Christmann V, Gradussen CJW, Rodwell L, Gotthardt M, Van Goudoever JB, et al. Growth and bone mineralization of very preterm infants at term corrected age in relation to different nutritional intakes in the early postnatal period. Nutrients. 2017 Dec 2; 9(12). pii: E1318. https://doi.org/ 10.3390/nu9121318 PMID: 29207479

54. Harding JE, Wilson J, Brown J. Calcium and phosphorus supplementation of human milk for preterm infants. Cochrane Database Syst Rev. 2017 Feb 26; 2:CD003310. https://doi.org/10.1002/14651858. CD003310.pub2 PMID: 28238222

55. Rigo J, Pieltain C, Christmann V, Bonsante F, Moltu SJ, lacobelli S, et al. Serum magnesium levels in preterm infants are higher than adult levels: A systematic literature review and meta-analysis. Nutrients. 2017 Oct 16; 9(10). pii:E1125. https://doi.org/10.3390/nu9101125 PMID: 29035309

56. Terrin G, Berni Canani R, Passariello A, Messina F, Conti MG, Caoci S, et al. Zinc supplementation reduces morbidity and mortality in very-low-birth-weight preterm neonates: a hospital-based randomized, placebo-controlled trial in an industrialized country. Am J Clin Nutr. 2013 Dec; 98(6):1468-74. https://doi.org/10.3945/ajcn.112.054478 PMID: 24025633

57. Kojima C, Shoji H, Ikeda N, Kitamura T, Hisata K, Shimizu T. Association of zinc and copper with clinical parameters in the preterm newborn. Pediatr Int. 2017 Nov; 59(11):1165-1168. https://doi.org/10.1111/ ped.13409 PMID: 28851072

58. Watson L, Cartwright D, Jardine LA, Pincus D, Koorts P, Kury S, et al. Transient neonatal zinc deficiency in exclusively breastfed preterm infants. J Paediatr Child Health. 2018 Mar; 54(3):319-322. https://doi.org/10.1111/jpc.13780 PMID: 29143460

59. Marquardt ML, Done SL, Sandrock M, Berdon WE, Feldman KW. Copper deficiency presenting as metabolic bone disease in extremely low birth weight, short-gut infants. Pediatrics. 2012 Sep; 130(3):e6958. https://doi.org/10.1542/peds.2011-1295 PMID: 22869833

60. Lava SA, Bianchetti MG, Simonetti GD. Salt intake in children and its consequences on blood pressure. Pediatr Nephrol. 2015 Sep; 30(9):1389-96. https://doi.org/10.1007/s00467-014-2931-3 PMID: 25127918

61. Isemann B, Mueller EW, Narendran V, Akinbi H. Impact of Early Sodium Supplementation on Hyponatremia and Growth in Premature Infants: A Randomized Controlled Trial. JPEN J Parenter Enteral Nutr. 2016 Mar; 40(3):342-9. https://doi.org/10.1177/0148607114558303 PMID: 25406227

62. Koo W, Tice $\mathrm{H}$. Human milk fortifiers do not meet the current recommendation for nutrients in very low birth weight infants. JPEN J Parenter Enteral Nutr. 2018 May; 42(4):813-820. https://doi.org/10.1177/ 0148607117713202 PMID: 28622483

63. Einloft PR, Garcia PC, Piva JP, Schneider R, Fiori HH, Fiori RM. Supplemented vs. unsupplemented human milk on bone mineralization in very low birth weight preterm infants: a randomized clinical trial. Osteoporos Int. 2015 Sep; 26(9): 2265-71. https://doi.org/10.1007/s00198-015-3144-8 PMID: 25971686 
64. Denning TL, Bhatia AM, Kane AF, Patel RM, Denning PW. Pathogenesis of NEC: Role of the innate and adaptive immune response. Semin Perinatol. 2017 Feb; 41(1):15-28. https://doi.org/10.1053/j. semperi.2016.09.014 PMID: 27940091

65. Peila C, Emmerik NE, Giribaldi M, Stahl B, Ruitenberg JE, van Elburg RM, et al. Human milk processing: A systematic review of innovative techniques to ensure the safety and quality of donor milk. $J$ Pediatr Gastroenterol Nutr. 2017 Mar; 64(3):353-361. https://doi.org/10.1097/MPG. 0000000000001435 PMID: 27755345

66. Ahrabi AF, Handa D, Codipilly CN, Shah S, Williams JE, McGuire MA, et al. Effects of extended freezer storage on the integrity of human milk. J Pediatr. 2016 Oct; 177:140-143. https://doi.org/10.1016/j. jpeds.2016.06.024 PMID: 27423174

67. Sousa SG, Delgadillo I, Saraiva JA. Effect of thermal pasteurisation and high-pressure processing on immunoglobulin content and lysozyme and lactoperoxidase activity in human colostrum. Food Chem. 2014 May 15; 151:79-85. https://doi.org/10.1016/j.foodchem.2013.11.024 PMID: 24423505

68. Gidrewicz DA, Fenton TR. A systematic review and meta-analysis of the nutrient content of preterm and term breast milk. BMC Pediatr. 2014 Aug 30; 14:216. https://doi.org/10.1186/1471-2431-14-216 PMID: 25174435

69. Dritsakou K, Liosis G, Valsami G, Polychronopoulos E, Skouroliakou. Improved outcomes of feeding low birth weight infants with predominantly raw human milk versus donor banked milk and formula. $J$ Matern Fetal Neonatal Med. 2016; 29(7):1131-8. https://doi.org/10.3109/14767058.2015.1038232 PMID: 25909500

70. Fischer Fumeaux CJ, Denis A, Prudon MB, Plaisant F, Essomo Megnier-Mbo CM, Fernandes L, et al. Early use of mother's own raw milk, maternal satisfaction, and breastfeeding continuation in hospitalised neonates: A prospective cohort study. Neonatology. 2018; 113(2):131-139. https://doi.org/10. 1159/000480535 PMID: 29186707

71. Choi A, Fusch G, Rochow N, Fusch C. Target fortification of breast milk: Predicting the final osmolality of the feeds. PLoS One. 2016 Feb 10; 11(2):e0148941. https://doi.org/10.1371/journal.pone.0148941 PMID: 26863130

72. de Halleux $\mathrm{V}$, Rigo J. Variability in human milk composition: benefit of individualized fortification in verylow-birth-weight infants. Am J Clin Nutr. 2013 Aug; 98(2):529S-35S. https://doi.org/10.3945/ajcn.112. 042689 PMID: 23824725

73. Rochow N, Fusch G, Choi A, Chessell L, Elliot L, McDonald K, et al. Target fortification of breast milk with fat, protein, and carbohydrates for preterm infants. J Pediatr. 2013 Oct; 163(4):1001-7. https://doi. org/10.1016/j.jpeds.2013.04.052 PMID: 23769498

74. Rochow N, Fusch G, Zapanta B, Ali A, Barui S, Fusch C. Target fortification of breast milk: how often should milk analysis be done? Nutrients. 2015 Apr 1; 7(4):2297-310. https://doi.org/10.3390/ nu7042297 PMID: 25835073 


\title{
Essential and toxic elements in human milk concentrate with human milk lyophilizate: A preclinical study
}

\author{
Mariana M. Oliveira ${ }^{\mathrm{a}}$, Tânia M.B. Trevilato ${ }^{\mathrm{b}}$, Susana I. Segura-Muñoz ${ }^{\mathrm{c}}$, Davi C. Aragon ${ }^{\mathrm{a}}$, \\ Larissa G. Alves ${ }^{\mathrm{d}}$, Martí Nadal ${ }^{\mathrm{e}}$, Montse Marquès ${ }^{\mathrm{e}}$, José L. Domingo ${ }^{\mathrm{e}}$, Jordi Sierra ${ }^{\mathrm{e}, \mathrm{f}}$, \\ José Simon Camelo Jr. ${ }^{\text {a,* }}$ \\ ${ }^{a}$ Department of Pediatrics, Childreńs Hospital, Ribeirão Preto Medical School, University of São Paulo, Ribeirão Preto, São Paulo, Brazil \\ ${ }^{\mathrm{b}}$ Section of Metals and Rare Diseases, Laboratory of Pediatrics, Clinics Hospital of Ribeirão Preto, Ribeirão Preto Medical School, University of São Paulo, Ribeirão Preto, \\ São Paulo, Brazil \\ ${ }^{\mathrm{c}}$ Laboratory of Ecotoxicology and Environmental Parasitology, Ribeirão Preto College of Nursing, University of São Paulo, Ribeirão Preto, São Paulo, Brazil \\ ${ }^{\mathrm{d}}$ Human Milk Bank, Clinics Hospital of Ribeirão Preto, Ribeirão Preto Medical School, University of São Paulo, Ribeirão Preto, São Paulo, Brazil \\ ${ }^{\mathrm{e}}$ Laboratory of Toxicology and Environmental Health, School of Medicine, IISPV, Universitat Rovira I Virgili, Reus, Catalonia, Spain \\ ${ }^{\mathrm{f}}$ Laboratory of Soil Science, Faculty of Pharmacy, Universitat de Barcelona, Catalonia, Spain
}

\section{A R T I C L E I N F O}

\section{Keywords:}

Human milk

Breast milk

Premature infant

Micronutrients

Biomonitoring

\begin{abstract}
A B S T R A C T
Concentrated human milk (HM-concentrate) can be obtained from the simple and inexpensive method of donated breast milk direct lyophilization. A previous study reported that HM-concentrate contains the adequate amount of main macro- and micronutrients for use as a nutritional resource for preterm infants with very low birth weight admitted to neonatal intensive care units. However, further details need to be elucidated about HMconcentrate composition, particularly its content of essential and potentially toxic trace elements. Therefore, this study aimed to determine the concentration of essential and toxic elements in human milk considered baseline (HM-baseline) and HM-concentrate, as well as to quantify changes in concentration of these elements after the HM concentration process. The concentration of Aluminum, Arsenic, Cadmium, Chromium, Iron, Mercury, Manganese, Nickel, Lead, Selenium, Tin, and Thallium was analyzed by inductively coupled plasma-mass spectrometry (ICP-MS). Moreover, Bayesian linear mixed effect models were applied to estimate the mean difference between HM-baseline and HM-concentrate samples. After comparison (HM-concentrate versus HMbaseline), a significant increase in concentration was observed only for Manganese $(0.80 \mu \mathrm{g} / \mathrm{L} ; 95 \% \mathrm{CrI}[0.16$; 1.43]) and Selenium $(6.74 \mu \mathrm{g} / \mathrm{L} ; 95 \% \mathrm{CrI}[4.66 ; 8.86])$, while Lead concentration $(-6.13 \mu \mathrm{g} / \mathrm{L}$; $95 \%$ CrI [-8.63; -3.61]) decreased. This study provides latest and reliable information about HM composition. After milk concentration by lyophilization, there was a significant increase only in the essential elements Manganese and Selenium. The essential micronutrient content in HM-concentrate was similar or higher than that in preterm mothers' milk, which suggests it is viable for nutritional support of preterm infants. In addition, the low concentrations of potentially toxic elements in HM-concentrate indicates that it is safe for consumption by premature newborns.
\end{abstract}

\section{Introduction}

Despite rising preterm survival rates, studies show that worldwide, an estimated $9-12 \%$ (12.65-16.73 million) of live births are premature (Chawanpaiboon et al., 2019). This significant figure suggests a need for improvement in neonatal nutritional support for preterm infants, especially in low and middle-income countries. Exclusive early enteral nutrition with human milk (HM) is an effective nutritional support strategy for feeding very low birth weight (VLBW) preterm infants.
Such practice is associated with lower incidence of necrotizing enterocolitis and neonatal mortality, with reduction in time and cost of hospitalization (Assad et al., 2016; Colaizy et al., 2016; Cortez et al., 2018).

Breast milk provides optimal nutrients and protective factors that enhance immune and gastrointestinal systems, as well as supports longterm neurodevelopment of VLBW preterm infants (Andreas et al., 2015; Brown et al., 2019; Patra et al., 2017; Sammallahti et al., 2017; Walker, 2010). Current recommendations emphasize that preterm newborn

\footnotetext{
${ }^{*}$ Corresponding author. Ribeirão Preto Medical School - University of São Paulo Bandeirantes, Av., 3900 - 5th floor - Off D506 - HC Criança, SP, Brazil.

E-mail addresses: jscamelo@fmrp.usp.br, jscamelo85@gmail.com (J.S. Camelo).
} 


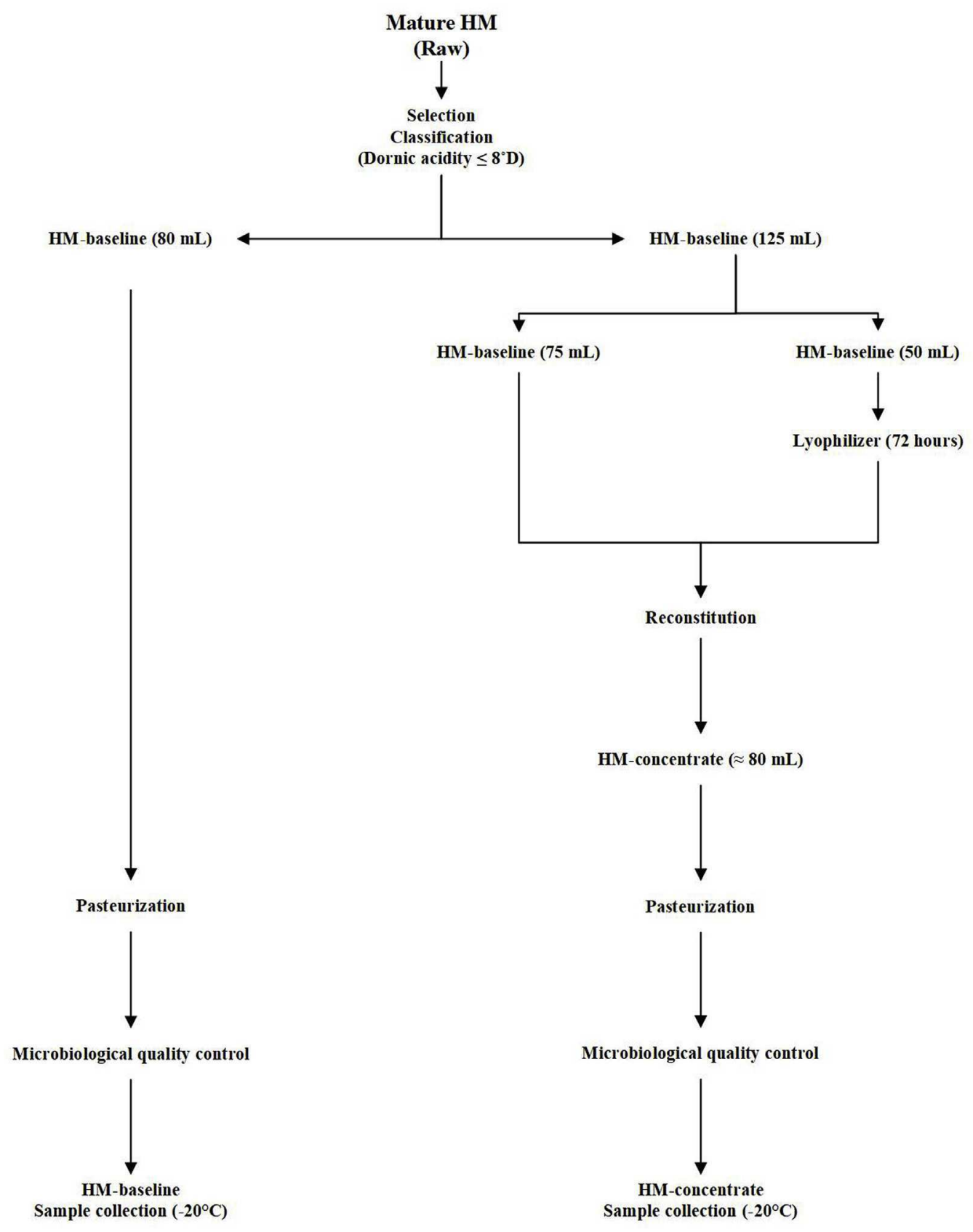

Fig. 1. Flowchart of processes applied to HM-baseline and HM-concentrate samples.

infants should receive the mother's milk or HM donated to the Human Milk Bank (HMB), plus commercial fortifiers to improve the milk composition, since milk is the singular nutritional source for infants (Bertino et al., 2013; Colaizy et al., 2012; Dutta et al., 2015; Valentine et al., 2017).

An innovative recent study produced HM-concentrate from a simple and inexpensive method of direct lyophilization of donated breast milk (Oliveira et al., 2019). This concentrated HM demonstrated microbiological safety, acceptable osmolality, and suitable nutritional composition of the main macro- and micronutrients needed by a VLBW preterm infant.

These findings can be translated to clinical trials to test this nutritional resource in preterm infants admitted to neonatal intensive care units. However, there are still not so well-defined aspects of HM-concentrate composition, such as essential and potentially toxic elements content, which could represent a risk for the health of premature infants. Therefore, this study aimed to determine the essential and potentially toxic elements concentration in HM-baseline and HM-concentrate samples, as well as to quantify changes in concentration of these elements after the HM concentration process. The expectation is that our findings confirm and reinforce the viability of HM-concentrate for nutritional support of very low birth weight preterm infants. Furthermore, these findings may have clinical relevance, and update information about mature breast milk composition, which will also be useful for HMB networks worldwide.

\section{Materials and methods}

This cross-sectional study was part of a recently published report approved by the Human Research Ethics Committee of the Clinics Hospital, Ribeirão Preto Medical School - USP (HREC Report No. 738.080), regarding development of a HM-concentrate with HM 
lyophilizate (Oliveira et al., 2019). Voluntary donors of surplus HM production were informed about the nature of the study, signed a free and informed consent form, and underwent clinical and serological screening. Criteria included being healthy, not smoking more than 10 cigarettes per day, not consuming alcohol or illegal drugs, and providing medical and laboratory exams.

\subsection{HM sample collection}

Donors with a lactation period greater than 15 days were given instructions about massaging and milking their breasts, and about how to withdraw the milk into a sterile, inert glass bottle provided by the HMB. All samples passed through the selection and classification processes recommended by the Brazilian HMB Network (available at: http://www.redeblh.fiocruz.br). A total of 50 samples ( $\geq 220 \mathrm{~mL}$ ) were collected, falling within a standard deviation of 0.36 of the expected average of protein concentration $(2.20 \mathrm{~g} / \mathrm{dL})$, absolute error value of 0.1 , and confidence level of $95 \%$. Surplus mature breast milk with a Dornic acidity value of up to $8^{\circ} \mathrm{D}$ was included in this study.

\subsection{HM-baseline and HM-concentrate sample generation}

Procedures applied to formulate HM-Baseline and HM-Concentrate samples in the HMB at the Clinics Hospital of Ribeirão Preto were recently reported (Oliveira et al., 2019). Briefly, HM-baseline samples were initially separated into two aliquots of 80 and $125 \mathrm{~mL}$ each: the $80 \mathrm{~mL}$ aliquot was considered the HM-baseline sample. To formulate the HM-concentrate sample, the $125 \mathrm{~mL}$ aliquot was further divided into two aliquots of 50 and $75 \mathrm{~mL}$. The $50 \mathrm{~mL}$ aliquot was transferred to an inert, sterile glass container and was frozen $\left(-20{ }^{\circ} \mathrm{C}\right.$ for $\left.24 \mathrm{~h}\right)$. Subsequently, the frozen sample was lyophilized under vacuum (Lyophilizer L108, LioTop ${ }^{\circledast}$, São Carlos - SP - Brazil). After 72 h, the lyophilized sample was reconstituted into the other $(75 \mathrm{~mL})$ aliquot reserved for the formulation of HM-concentrate. All samples were subjected to pasteurization and microbiological quality control as recommended by the Brazilian HMB Network. In collection tubes, aliquots were separated and immediately frozen $\left(-20^{\circ} \mathrm{C}\right)$ for transport and subsequent analysis. Procedures applied to HM-baseline and HMconcentrate samples are shown in Fig. 1.

\subsection{Essential and toxic element analysis}

Concentrations of essential and potentially toxic elements were analyzed in HM-baseline and HM-concentrate samples at two different timepoints. Preliminary sample preparation was performed in the Laboratory of Pediatrics, Section of Metals and Rare Diseases, Clinics Hospital of Ribeirão Preto, Ribeirão Preto Medical School, University of São Paulo, Ribeirão Preto, São Paulo, Brazil. Samples were thawed at room temperature followed by heating in a water bath $\left(37^{\circ} \mathrm{C}\right)$ and homogenized by sonication for $10 \mathrm{~min}$. Aliquots $(1 \mathrm{~mL})$ of the samples were chemically digested with $1 \mathrm{~mL}$ of $65 \%$ Suprapur nitric acid (Merck $\mathrm{KGaA}^{\circledR}$, Darmstadt, Germany) in hermetic Teflon vessels at room temperature overnight $(12 \mathrm{~h})$, followed by heating $\left(80{ }^{\circ} \mathrm{C}\right)$ for $8 \mathrm{~h}$ in a hot plate (FANEM ${ }^{\oplus}$, Model 315 SE, São Paulo, Brazil). Digested samples were diluted by $1: 5$ using ultrapure water and were sent for analysis by the Laboratory of Toxicology and Environmental Health, School of Medicine, Universitat Rovira i Virgili (Reus, Catalonia, Spain). Following 1:5 dilution with 1\% nitric acid (Merck KGaA, Darmstadt, Germany), the concentration of Aluminum (Al), Arsenic (As), Cadmium (Cd), Chromium (Cr), Iron (Fe), Mercury (Hg), Manganese (Mn), Nickel $(\mathrm{Ni})$, Lead $(\mathrm{Pb})$, Selenium (Se), Tin (Sn), and Thallium (Tl) was analyzed by inductively coupled plasma-mass spectrometry (ICP-MS; PerkinElmer $^{\circledast}$ NexION 350D). Reference certificates, duplicates and laboratory blanks were used as quality control to ensure method accuracy and precision. The limit of quantification (LOQ) and limit of detection (LOD) were, respectively: 12.5 and $6.25 \mu \mathrm{g} / \mathrm{L}$ for Al; 0.1 and
$0.05 \mu \mathrm{g} / \mathrm{L}$ for As, Cd, and Tl; 2.0 and $1.0 \mu \mathrm{g} / \mathrm{L}$ for Cr; 0.2 and $0.1 \mu \mathrm{g} / \mathrm{L}$ for $\mathrm{Hg} ; 20.0$ and $10.0 \mu \mathrm{g} / \mathrm{L}$ for Fe; 1.25 and $0.625 \mu \mathrm{g} / \mathrm{L}$ for $\mathrm{Mn}, \mathrm{Ni}, \mathrm{Pb}$ and Sn; and 2.5 and $1.25 \mu \mathrm{g} / \mathrm{L}$ for Se.

\subsection{Statistical analysis}

Mean values, standard deviation (SD), and minimum and maximum values were used to statistically analyze the essential and toxic element concentrations. Bayesian linear mixed effect models were adjusted using OpenBUGS to estimate mean difference and 95\% credible intervals when comparing essential and toxic elements concentrations between HM-baseline and HM-concentrate samples.

\section{Results and discussion}

\subsection{Characteristics of study population}

After selection and classification processes based upon donor inclusion criteria ( $\mathrm{n}=50$ donors), the mean Dornic acid value was $4.34^{\circ} \mathrm{D}$ and the standard deviation (SD) was 1.59 . The mean age, weight, height, and gestational age of the donors was, respectively, 30 years ( $S D=6), 67.5 \mathrm{~kg}(\mathrm{SD}=11.9), 1.63 \mathrm{~m}$ ( $\mathrm{SD}=0.59)$, and 38.4 weeks (SD $=2.3$ ). All donors reported that they did not smoke or consume alcohol and/or drugs at the time of clinical screening.

\subsection{Descriptive results}

Descriptive statistics (Mean, SD, maximum and minimum values) for essential and potentially toxic elements concentration $(\mu \mathrm{g} / \mathrm{L})$ in HMbaseline and HM-concentrate are summarized in Table 1.

One sample was discarded from the statistical analysis due to possible external contamination. Comparative results of essential and toxic elements concentration in HM-baseline and HM-concentrate samples are presented in Table 2.

After comparison between HM-concentrate (T2) and HM-baseline (T1), a significant increase was observed in the concentration of only the essential elements $\mathrm{Mn}(0.80 \mu \mathrm{g} / \mathrm{L} ; 95 \% \mathrm{CrI}[0.16 ; 1.43])$ and $\mathrm{Se}$ $(6.74 \mu \mathrm{g} / \mathrm{L} ; 95 \% \mathrm{CrI}[4.66 ; 8.86])$, while the concentration of the toxic element $\mathrm{Pb}(-6.13 \mu \mathrm{g} / \mathrm{L}$; 95\% CrI $[-8.63 ;-3.61])$ decreased. There was no significant difference in the concentration of other elements (Al, As, Cd, Cr, Fe, Hg, Ni, Sn, and Tl) between HM-concentrate (T2) and HM-baseline (T1).

Table 1

Descriptive statistics (mean, standard deviation (SD), and maximum and minimum values) of essential and potentially toxic elements concentration ( $\mu \mathrm{g}$ / L) in HM-baseline and HM-concentrate $(n=49)$.

\begin{tabular}{lllllll}
\hline \multirow{2}{*}{ Element } & HM-baseline & \multicolumn{5}{c}{ HM-concentrate } \\
\cline { 2 - 7 } & Mean (SD) & Min & Max & Mean (SD) & Min & Max \\
\hline Al & 211.06 & 112.30 & 574.60 & 202.21 & 121.00 & 413.90 \\
& $(90.06)$ & & & $(69.30)$ & & \\
As & $0.29(0.13)$ & $<$ LOQ & 0.63 & $0.29(0.14)$ & $<$ LOQ & 0.80 \\
Cd & $0.37(0.19)$ & $<$ LOQ & 0.96 & $0.35(0.25)$ & 0.10 & 1.18 \\
Cr & $4.39(1.57)$ & 2.32 & 8.93 & $5.65(5.34)$ & 2.63 & 29.81 \\
Fe & 673.55 & 321.40 & 1608.90 & 756.95 & 313.40 & 1762.50 \\
& $(264.05)$ & & & $(279.39)$ & & \\
Hg & $0.39(0.25)$ & $<$ LOQ & 1.68 & $0.42(0.20)$ & $<$ LOQ & 1.25 \\
Mn & $5.07(1.28)$ & 2.75 & 9.14 & $5.88(1.92)$ & 2.94 & 15.08 \\
Ni & $6.34(3.46)$ & 2.96 & 25.64 & $6.06(3.72)$ & 2.65 & 20.42 \\
Pb & $12.79(8.19)$ & 2.17 & 41.94 & $6.69(3.14)$ & 2.72 & 19.63 \\
Se & $7.89(4.63)$ & $<$ LOQ & 27.60 & $14.60(7.16)$ & $<$ LOQ & 27.50 \\
Sn & $2.78(1.48)$ & $<$ LOQ & 9.46 & $3.26(4.19)$ & $<$ LOQ & 25.01 \\
Tl & $<$ LOQ & $<$ LOQ & 0.30 & $0.10(0.12)$ & $<$ LOQ & 0.63 \\
& $(0.06)$ & & & & & \\
\hline
\end{tabular}

LOQ: Limit of quantification. 
Table 2

Mean difference between essential and potentially toxic elements concentration $(\mu \mathrm{g} / \mathrm{L})$ in HM-baseline (T1) and HM-concentrate (T2) $(\mathrm{n}=49)$.

\begin{tabular}{lllll}
\hline Element & Comparison & $\begin{array}{l}\text { Mean } \\
\text { difference }\end{array}$ & $\begin{array}{l}\text { 95\% CrI Lower } \\
\text { limit }\end{array}$ & $\begin{array}{l}\text { 95\% CrI Upper } \\
\text { limit }\end{array}$ \\
\hline Al & T2 - T1 & -7.99 & -39.65 & 23.67 \\
As & T2 - T1 & -0.004 & -0.05 & 0.04 \\
Cd & T2 - T1 & -0.02 & -0.11 & 0.07 \\
Cr & T2 - T1 & 1.25 & -0.31 & 2.70 \\
Fe & T2 - T1 & 72.76 & -29.93 & 171.65 \\
Hg & T2 - T1 & 0.03 & -0.05 & 0.12 \\
Mn & T2 - T1 & 0.80 & 0.16 & 1.43 \\
Ni & T2 - T1 & -0.28 & -1.62 & 1.17 \\
Pb & T2 - T1 & -6.13 & -8.63 & -3.61 \\
Se & T2 - T1 & 6.74 & 4.66 & 8.86 \\
Sn & T2 - T1 & 0.48 & -0.70 & 1.68 \\
T1 & T2 - T1 & 0.03 & -0.01 & 0.06 \\
\hline
\end{tabular}

T1 - HM-baseline; T2 - HM-concentrate; 95\% CrI: Credible Interval 95\%.

\subsection{General findings}

This study evaluated the concentration of essential and potentially toxic trace elements in HM-baseline and HM-concentrate samples and quantified changes in the levels of these elements after the concentration process. A significant increase (HM-concentrate versus HM-baseline) in the concentration of the essential elements $\mathrm{Mn}$ and Se was found, while concentration of potentially toxic element $\mathrm{Pb}$ decreased. Interestingly, the present study provides updated and reliable information about the composition of mature breast milk (HM-baseline) processed by the Brazilian HMB Network, which should be also useful for HMB networks worldwide.

\subsection{Essential elements in $H M$}

Premature and low birth weight infants have slightly higher requirements of essential micronutrients such as $\mathrm{Cr}, \mathrm{Fe}, \mathrm{Mn}$, and Se due to the rapid postnatal growth and development, iatrogenic losses, and limited body storage of these elements. Premature birth interrupts the mother's transfer of these nutrients during the third trimester of gestation. Thus, such infants are at increased risk of developing nutritional deficiencies, such as iron deficiency anemia (Finch, 2015; Harding et al., 2017).

Iron plays a crucial role in the metabolic pathway of energy production, in oxygen transport, and in erythropoiesis. It also aids in the growth and neurodevelopment of preterm infants (Moreno-Fernandez et al., 2019). A recent systematic review indicates that long-term Fe supplementation results in improved Fe levels and a reduction in iron deficiency anemia in VLBW preterm infants (McCarthy et al., 2019). The present study highlights that $\mathrm{Fe}$ is a predominant essential micronutrient in HM-baseline and HM-concentrate samples (Table 1). Previous studies conducted in Greece (Leotsinidis et al., 2005), Sweden (Björklund et al., 2012), Chile (Castro et al., 2014), Australia (MohdTaufek et al., 2016), Switzerland (Sabatier et al., 2019), and Brazil (Alves Peixoto et al., 2019) detected lower Fe content in breast milk compared to the values found in the present study (Table A1). Furthermore, Fe content in HM samples collected 1-2 months postpartum was higher than in samples collected after 6-7 months and 12 months of lactation (Taravati Javad et al., 2018). Therefore, despite the higher baseline Fe content of the HM-baseline used in the present study, the concentration process maintained the high Fe content (Table 2).

Furthermore, a cross-sectional study demonstrated a positive correlation between $\mathrm{Fe}$ and $\mathrm{Mn}$ concentration at all stages of lactation ( $\mathrm{Li}$ et al., 2016). Therefore, like Fe, Mn content also decreases over the lactation stages of colostrum, transitional, and mature milk (Björklund et al., 2012). In addition, Mn concentrations in human milk differs among specific populations (Poland, USA, Argentina, and Namibia;
Table A1) (Klein et al., 2017). Interestingly, a study conducted on Brazilian breast milk showed a very low Mn content (Cardoso et al., 2014). However, our study found a higher Mn content in HM-baseline, as well as a significant increase of $0.80 \mu \mathrm{g} / \mathrm{L}$ in HM-concentrate (Table 2). Manganese is an enzymatic cofactor in carbohydrate and lipid metabolism, and also essential micronutrient for growth and bone development (ATSDR, 2012c; Kumar et al., 2017). The higher Mn content in HM-concentrate could positively impact the health of VLBW preterm infants. Likewise, it has been suggested that Fe and Mn content in mothers' milk does not meet the nutritional requirements of preterm infants (Table A1). Consequently, due to its high Fe and Mn content, we believe that our HM-concentrate may be a viable alternative for the nutritional support of premature infants.

Selenium is another essential micronutrient with a high concentration in HM-baseline and a significant increase in concentration in HMconcentrate (Tables 1 and 2). Studies conducted in Sweden (Björklund et al., 2012), Chile (Castro et al., 2014), Australia (Mohd-Taufek et al., 2016), Switzerland (Sabatier et al., 2019), and Slovenia (Jagodic et al., 2020; Snoj Tratnik et al., 2019) indicate similar Se concentrations to those reported in the present study (Table A1). Significantly, Se has been highlighted as an important element for optimal function of antioxidant defense systems in preterm infants (Tindell and Tipple (2018)). Selenoenzymes, including glutathione peroxidase, protect the body against free radical damage that contributes to risk for prematurity diseases such as bronchopulmonary dysplasia, retinopathy of prematurity, and necrotizing enterocolitis (Finch, 2015). The Se content in HM-concentrate is similar to that in mother's milk of preterm infants. Consequently, it indicates suitability of HM-concentrate for use in premature newborns (Sabatier et al., 2019). This speculation is supported by the fact that the milk from mothers of preterm infants has a mean Se content of $16.1 \mu \mathrm{g} / \mathrm{L}$, which meets the nutritional requirements of premature newborns (Alves Peixoto et al., 2019). In contrast, micronutrients such as Se and $\mathrm{Cr}$ are absent in most commercial human milk fortifiers, suggesting that they do not meet the nutritional needs of premature newborns (Koo and Tice (2018)).

Small doses of the essential nutrient $\mathrm{Cr}$ are required for proper energy metabolism (ATSDR, 2012b). The mean Cr level in HM-concentrate was similar to that found in a recent study (Samiee et al., 2019) of Iranian breast milk (Table A1). However, previous surveys conducted in Sweden (Björklund et al., 2012) and Brazil (Cardoso et al., 2014) reported very low $\mathrm{Cr}$ content in HM (Table A1). Importantly, Holder pasteurization by thermal treatment applied to HMB, as performed in the present study, does not affect Fe, Mn, and Se content in breast milk (Alves Peixoto et al., 2019; Mohd-Taufek et al., 2016).

\subsection{Potentially toxic elements in $H M$}

Breast milk is non-invasive biomonitoring matrix of exposures to harmful elements such as $\mathrm{Al}, \mathrm{As}, \mathrm{Cd}, \mathrm{Hg}$ and $\mathrm{Pb}$. Toxic organic substances, as well as toxic trace elements, which have been accumulate in the tissues of mothers can cross the mammary glands, exposing newborns to postnatal contamination through HM intake. Potential damage to neonatal growth and development caused by these toxic elements may be severe and permanent (Bansa et al., 2017; Bassil et al., 2018; Bastos et al., 2018; Gil and Hernández (2015); Letinić et al., 2016; Rebelo and Caldas, 2016). Early exposure to excessive amounts of these potentially toxic elements can contribute to long-term adverse health effects, such as neurodevelopmental disorders and damage to immune and respiratory functions (Cao et al., 2016; Heyer and Meredith (2017)). In general, breast milk has a low concentration of potentially toxic elements. Importantly, the concentration of the toxic microelements $\mathrm{Al}, \mathrm{As}, \mathrm{Cd}$, and $\mathrm{Pb}$ decrease rapidly and significantly over the stages of lactation (Chao et al., 2014; Martínez et al., 2019). Thus, it is expected that mature milk used in our HM-concentrate may be safe for the nutritional support of premature newborns.

Aluminum is the most abundant metal in the earth's crust (soil, 
water, and air), as well as the most frequent and highly concentrated element in breast milk (ATSDR, 2008; Bastos et al., 2018). However, Al concentration in our HM-baseline and HM-concentrate was lower than that reported by studies conducted in Iran (Taravati Javad et al., 2018) and Spain (Martínez et al., 2019) (Table A2). It is important to note that only a small amount of $\mathrm{Al}$ enters the infant's body through breastfeeding (ATSDR, 2008). However, the sources of Al exposure may be also contaminated by $\mathrm{Pb}$, As, and $\mathrm{Cd}$ (Weidenhamer et al., 2017), where As is the most toxic of these elements.

Exposure of lactating mothers to As may occur through drinking water, as well as via consumption of contaminated rice/cereals, fish/ seafood, mushrooms, and poultry (ATSDR, 2007; Bassil et al., 2018). The "Priority List of Substances" released in 2017 by the Agency for Toxic Substance and Disease Registry ranked Arsenic as the potentially most hazardous element to human health. The low As concentration in our HM samples was comparable to other studies performed in Sweden (Björklund et al., 2012), Chile (Castro et al., 2014), USA (Carignan et al., 2015), Turkey (Kılıç Altun et al., 2018), and Slovenia (Jagodic et al., 2020; Snoj Tratnik et al., 2019) (Table A2). However, two studies (Bassil et al., 2018; Klein et al., 2017) showed higher mean As concentrations than reported in the present study ( $>2 \mu \mathrm{g} / \mathrm{L}$ ). Nevertheless, only a negligible amount of As is excreted in breast milk, even in highly exposed mothers (Fängström et al., 2008). Furthermore, it has been emphasized that mixed breastfed babies ingested higher As amounts than exclusive breastfeeding group (Castro et al., 2014). Thus, our innovative proposal based on exclusive breast milk diet could be protective to VLBW against As exposure.

Lead, $\mathrm{Hg}$, and $\mathrm{Cd}$ are harmful toxic elements that must be taken into account and analyzed in certain regions, particularly in developing countries, to avoid the risk of exposure to infants (ATSDR, 2019; Klein et al., 2017; Pajewska-Szmyt et al., 2019; Rebelo and Caldas, 2016; Samiee et al., 2019).

Mobilization of $\mathrm{Pb}$ stored in mother's bones is the main route of $\mathrm{HM}$ contamination, and consequent infant exposure may cause damage to neurological development (Chao et al., 2014). Fortunately, the $\mathrm{Pb}$ content in breast milk is low despite high $\mathrm{Pb}$ concentration in maternal blood (Baranowska-Bosiacka et al., 2016). The mean Pb concentration in breast milk ranges from 2.0 to $16.8 \mu \mathrm{g} / \mathrm{L}$, as reported by a major multicenter study conducted by the World Health Organization (WHO) (WHO/IAEA, 1989). Recently, two cross-sectional studies conducted in Iran detected high $\mathrm{Pb}$ levels in HM. Gasoline, food, water, dust, and cosmetics (lipstick) were identified as possible contamination sources (Khanjani et al., 2018; Vahidinia et al., 2019). However, the present study found a mean $\mathrm{Pb}$ concentration in HM-baseline similar to another Brazilian study (Marques et al., 2013), and the values were within acceptable WHO limits (WHO/IAEA, 1989). Interestingly, the concentration process to produce HM-concentrate resulted in a significant reduction of $\mathrm{Pb}$ content compared to HM-baseline (Table 2). A study of lactating Lebanese women found a slightly higher mean $\mathrm{Pb}$ concentration compared to the concentration observed in the current survey (Table A2) (Bassil et al., 2018). This study also demonstrated a positive association between pre-pregnancy smoking and $\mathrm{Pb}$ and $\mathrm{Cd}$ levels in breast milk (Bassil et al., 2018).

Cadmium is found in the earth's crust (air, water, and soil) and is associated with $\mathrm{Zn}, \mathrm{Pb}$, and $\mathrm{Cu}$ ores (ATSDR, 2012a). Tobacco leaves accumulate high Cd levels, and consequently maternal consumption of tobacco or exposure to tobacco smoke enhanced the risk of infant exposure (ATSDR, 2012a; Bassil et al., 2018). Although smoking during pregnancy increased Cd levels in HM by 37\%, there was a non-significant increase associated with the number of smoked cigarettes per day (García-Esquinas et al., 2011). Moreover, an Iranian study detected a higher Cd concentration in breast milk of non-smoking mothers (Khanjani et al., 2018). Cadmium concentrations in breast milk from nursing Brazilian mothers ranged from $<0.05$ to $7.0 \mu \mathrm{g} / \mathrm{L}$ (Cardoso et al., 2014), while the present study detected even lower Cd concentrations in HM-concentrate samples. In addition, these values do not exceed the WHO reported limit ( $1 \mu \mathrm{g} / \mathrm{L}$ ) (WHO/IAEA, 1989), which is not surprising since Brazil strongly recommends against smoking during prenatal care.

Further, a low level of Ni was found in our HM samples, being the Ni concentration lower than that reported in previous studies conducted in Spain (Martínez et al., 2019) and Iran (Salmani et al., 2016) (Table A2). However, investigations conducted in Sweden (Björklund et al., 2012) and Brazil (Cardoso et al., 2014) found Ni levels in HM even lower than observed in the present study (Table A2). Nickel concentrations in breast milk ranged from 4.9 to $16.1 \mu \mathrm{g} / \mathrm{L}$ according to WHO (WHO/ IAEA, 1989). The Agency for Toxic Substance and Disease Registry indicates that the Ni concentration in breast milk is either similar to or less than that in cow's milk-based or soy-based infant formula (ATSDR, 2005). Contaminated water and food, as well as inhalation of tobacco smoke may increase the Ni concentration in breast milk (Salmani et al., 2016). The low Pb, Cd, and Ni concentrations found in this study are possibly due to the non-smoking habits reported by our breast milk donors.

The present study also identified low $\mathrm{Hg}$ content in HM samples. Similar to $\mathrm{Pb}, \mathrm{Hg}$ is excreted in breast milk from exposed mothers, and may affect infant neurodevelopment, causing irreversible damage (ATSDR, 1999; WHO, 2008). A multicenter WHO study identified that the normal range for $\mathrm{Hg}$ concentration in $\mathrm{HM}$ is $1.4-3.3 \mu \mathrm{g} / \mathrm{L}$ (WHO/ IAEA, 1989). Moreover, recent studies have shown that breast milk $\mathrm{Hg}$ levels range from 0.5 to $7.0 \mu \mathrm{g} / \mathrm{L}$ worldwide (Cunha et al., 2013; García-Esquinas et al., 2011; Rebelo and Caldas, 2016; Vahidinia et al., 2019). Although some studies have reported a positive correlation between fish consumption and $\mathrm{Hg}$ accumulation in breast milk, a recent cross-sectional study showed no association between these factors (Behrooz et al., 2012; Letinić et al., 2016; Vahidinia et al., 2019).

Overall, our study confirms the optimal quality of donated breast milk, since only low concentrations of the potentially toxic elements $\mathrm{Al}$, $\mathrm{As}, \mathrm{Pb}, \mathrm{Cd}$, and $\mathrm{Hg}$ were detected in $\mathrm{HM}$ samples. Lastly, studies related to the concentration of $\mathrm{Sn}$ and $\mathrm{Tl}$ in breast milk remain scarce. A multicenter WHO study reported an Sn concentration ranging from 1.4 to $3.3 \mu \mathrm{g} / \mathrm{L}$ in HM, which is comparable with our findings (WHO/IAEA, 1989). Although prenatal Tl exposure could increase the risk of prematurity and low birth weight (Qi et al., 2019; Wu et al., 2019), Tl content in breast milk has not yet been investigated (WHO/IAEA, 1989).

\subsection{Study limitations}

Limitations of this study include the fact that the dietary patterns of the milk donors were not studied, which could have been integrated with the analysis of breast milk elemental composition. Furthermore, the number of donors was limited number due to the difficulties of collecting samples as human milk donations are scarce. Furthermore, the number of donors was rather limited due to the difficulties of collecting samples, taking into account that human milk donations are scarce. Nevertheless, the results of this investigation provide updated and reliable information about breast milk composition. Furthermore, we demonstrate that the HM lyophilization and concentration processes are safe, since only low concentrations of the potentially toxic elements $\mathrm{Al}, \mathrm{As}, \mathrm{Pb}, \mathrm{Cd}$, and $\mathrm{Hg}$ were detected in $\mathrm{HM}$-concentrate samples. However, further studies of HM-concentrate are still necessary in order to assess the safety and tolerability for the effective nutritional support of preterm infants.

\section{Conclusions}

Assessment of essential and toxic elements concentration in HMconcentrate confirms and reinforces the viability of this product specially developed to support the effective nutritional requirements of premature infants. Essential micronutrient content in HM-concentrate was similar to or better than that in preterm mothers' milk, which 
clearly suggests it can be used for preterm infants. In addition, the low content of toxic elements indicates a low risk for premature newborns. Furthermore, the present study provides updated and reliable information about the composition of mature breast milk (HM-baseline), which should be also useful for HMB networks worldwide.

Phase 1 , randomized, controlled, double-blinded clinical trial is underway to assess the safety, tolerability, and initial performance of our HM-concentrate as a nutritional support resource for VLBW infants.

\section{Author contribution}

Mariana M. Oliveira: Conceptualization, Data curation, Formal analysis, Investigation, Methodology, Visualization, Writing - original draft. Tânia M. B. Trevilato: Conceptualization, Data curation, Investigation, Methodology, Resources, ValidationWriting - Writing review \& editing. Susana I. Segura-Muñoz: Data curation, Investigation, Methodology, Resources, Validation and Writing - review \& editing. Davi C. Aragon: Formal analysisWriting - Writing - review \& editing. Larissa G Alves: InvestigationResources. Martí Nadal: Investigation, Methodology, Resources, ValidationWriting - Writing - review \& editing. Montse Marquès: Validation and Writing - review \& editing. José L. Domingo: Investigation, Methodology, Resources, Validation and Writing - review \& editing. Jordi Sierra: Investigation, Methodology, Resources, Validation and Writing - review \& editing. José Simon Camelo Jr: Conceptualization, Funding acquisition, Project administration, Resources and Writing - review \& editing.

\section{Declaration of competing interest}

No conflicts of interest.

\section{Acknowledgements}

The present study was supported by Bill and Melinda Gates Foundation (Grand Challenges Brazil), Grant \# OPP1107597 to JSC Jr., CNPq - Conselho Nacional de Desenvolvimento Científico e Tecnológico, Brazil, Grant \# 401612/2013-9 to JSC Jr., and Ministry of Health / Department of Science and Technology, Brazil. This study was financed in part by the Coordenação de Aperfeiçoamento de Pessoal de Nível Superior - Brasil (CAPES) - Finance Code 001. The funders had no role in study design, data collection and analysis, decision to publish, or preparation of the manuscript.

\section{Appendix A. Supplementary data}

Supplementary data to this article can be found online at https:// doi.org/10.1016/j.envres.2020.109733.

\section{References}

Alves Peixoto, R.R., Bianchi Codo, C.R., Lacerda Sanches, V., Guiraldelo, T.C., Ferreira da Silva, F., Ribessi, R.L., Martins Marba, S.T., Cadore, S., 2019. Trace mineral composition of human breast milk from Brazilian mothers. J. Trace Elem. Med. Biol. 54, 199-205. https://doi.org/10.1016/j.jtemb.2019.05.002.

Andreas, N.J., Kampmann, B., Mehring Le-Doare, K., 2015. Human breast milk: a review on its composition and bioactivity. Early Hum. Dev. 91 (11), 629-635. https://doi. org/10.1016/j.earlhumdev.2015.08.013.

Assad, M., Elliott, M.J., Abraham, J.H., 2016. Decreased cost and improved feeding tolerance in VLBW infants fed an exclusive human milk diet. J. Perinatol. 36 (3), 216-220. https://doi.org/10.1038/jp.2015.168.

ATSDR. Agency for Toxic Substances and Disease Registry, 1999. Toxicological Profile for Mercury. US Department of Health and Human Services, Public Health Service, Atlanta, GA.

ATSDR. Agency for Toxic Substances and Disease Registry, 2005. Toxicological Profile for Nickel. U.S. Department of Health and Human Services, Public Health Services, Atlanta, GA.

ATSDR. Agency for Toxic Substances and Disease Registry, 2007. Toxicological Profile for Arsenic. U.S. Department of Health and Human Services, Public Health Services, Atlanta, GA.

ATSDR. Agency for Toxic Substances and Disease Registry, 2008. Toxicological Profile for
Aluminum. U.S. Department of Health and Human Services, Public Health Services, Atlanta, GA.

ATSDR. Agency for Toxic Substances and Disease Registry, 2012. Toxicological Profile for Cadmium. U.S. Department of Health and Human Services, Public Health Services, Atlanta, GA.

ATSDR. Agency for Toxic Substances and Disease Registry, 2012. Toxicological Profile for Chromium. U.S. Department of Health and Human Services, Public Health Services, Atlanta, GA.

ATSDR. Agency for Toxic Substances and Disease Registry, 2012. Toxicological Profile for Manganese. U.S. Department of Health and Human Services, Public Health Services, Atlanta, GA.

ATSDR. Agency for Toxic Substances and Disease Registry, 2019. Toxicological Profile for Lead. U.S. Department of Health and Human Services, Public Health Services, Atlanta, GA.

Bansa, D.K., Awua, A.K., Boatin, R., Adom, T., Brown-Appiah, E.C., Amewosina, K.K., Diaba, A., Datoghe, D., Okwabi, W., 2017. Cross-sectional assessment of infants' exposure to toxic metals through breast milk in a prospective cohort study of mining communities in Ghana. BMC Publ. Health 17 (1), 505. https://doi.org/10.1186/ s12889-017-4403-8.

Baranowska-Bosiacka, I., Kosińska, I., Jamioł, D., Gutowska, I., Prokopowicz, A., RębaczMaron, E., Goschorska, M., Olszowski, T., Chlubek, D., 2016. Environmental lead $(\mathrm{Pb})$ exposure versus fatty acid content in blood and milk of the mother and in the blood of newborn children. Biol. Trace Elem. Res. 170 (2), 279-287. https://doi.org/ 10.1007/s12011-015-0482-5.

Bassil, M., Daou, F., Hassan, H., Yamani, O., Kharma, J.A., Attieh, Z., Elaridi, J., 2018. Lead, cadmium and arsenic in human milk and their socio-demographic and lifestyle determinants in Lebanon. Chemosphere 191, 911-921. https://doi.org/10.1016/j. chemosphere.2017.10.111.

Bastos, W.R., Vieira, S.M., Manzatto, Â.G., Dórea, J.G., Rubira, M.C., de Souza, V.F.P., da Costa Junior, W.A., Souza Bastos, M.T., 2018. Heterogeneity of multimedia exposures to neurotoxic elements ( $\mathrm{Al}, \mathrm{As}, \mathrm{Cd}, \mathrm{Pb}, \mathrm{Mn}$, and $\mathrm{Hg}$ ) in breastfed infants from Porto Velho, Brazil. Biol. Trace Elem. Res. 184 (1), 7-15. https://doi.org/10.1007/s12011017-1165-1.

Behrooz, R.D., Esmaili-Sari, A., Peer, F.E., Amini, M., 2012. Mercury concentration in the breast milk of Iranian women. Biol. Trace Elem. Res. 147 (1-3), 36-43. https://doi. org/10.1007/s12011-011-9283-7.

Bertino, E., Giuliani, F., Baricco, M., Di Nicola, P., Peila, C., Vassia, C., Chiale, F., Pirra, A., Cresi, F., Martano, C., Coscia, A., 2013. Benefits of donor milk in the feeding of preterm infants. Early Hum. Dev. 89 (Suppl. 2), S3-S6. https://doi.org/10.1016/j. earlhumdev.2013.07.008.

Björklund, K.L., Vahter, M., Palm, B., Grandér, M., Lignell, S., Berglund, M., 2012. Metals and trace element concentrations in breast milk of first time healthy mothers: a biological monitoring study. Environ. Health 11, 92. https://doi.org/10.1186/1476 069X-11-92.

Brown, J.V.E., Walsh, V., McGuire, W., 2019. Formula versus maternal breast milk for feeding preterm or low birth weight infants. Cochrane Database Syst. Rev. 8, CD002972. https://doi.org/10.1002/14651858.CD002972.pub3.

Cao, J., Xu, X., Hylkema, M.N., Zeng, E.Y., Sly, P.D., Suk, W.A., Bergman, Å., Huo, X. 2016. Early-life exposure to widespread environmental toxicants and health risk: a focus on the immune and respiratory systems. Ann Glob Health 82 (1), 119-131. https://doi.org/10.1016/j.aogh.2016.01.023.

Cardoso, O.O., Julião, F.C., Alves, R.I., Baena, A.R., Díez, I.G., Suzuki, M.N., Celere, B.S. Nadal, M., Domingo, J.L., Segura-Muñoz, S.I., 2014. Concentration profiles of metals in breast milk, drinking water, and soil: relationship between matrices. Biol. Trace Elem. Res. 160 (1), 116-122. https://doi.org/10.1007/s12011-014-0030-8.

Carignan, C.C., Cottingham, K.L., Jackson, B.P., Farzan, S.F., Gandolfi, A.J., Punshon, T., Folt, C.L., Karagas, M.R., 2015. Estimated exposure to arsenic in breastfed and formula-fed infants in a United States cohort. Environ. Health Perspect. 123 (5), 500-506. https://doi.org/10.1289/ehp.1408789.

Castro, F., Harari, F., Llanos, M., Vahter, M., Ronco, A.M., 2014. Maternal-child transfer of essential and toxic elements through breast milk in a mine-waste polluted area. Am. J. Perinatol. 31 (11), 993-1002. https://doi.org/10.1055/s-0034-1370343.

Chao, H.H., Guo, C.H., Huang, C.B., Chen, P.C., Li, H.C., Hsiung, D.Y., Chou, Y.K., 2014. Arsenic, cadmium, lead, and aluminium concentrations in human milk at early stages of lactation. Pediatr Neonatol 55 (2), 127-134. https://doi.org/10.1016/j.pedneo. 2013.08.005.

Chawanpaiboon, S., Vogel, J.P., Moller, A.B., Lumbiganon, P., Petzold, M., Hogan, D., Landoulsi, S., Jampathong, N., Kongwattanakul, K., Laopaiboon, M., Lewis, C., Rattanakanokchai, S., Teng, D.N., Thinkhamrop, J., Watananirun, K., Zhang, J., Zhou, W., Gülmezoglu, A.M., 2019. Global, regional, and national estimates of levels of preterm birth in 2014: a systematic review and modelling analysis. Lancet Glob Health 7 (1), e37-e46. https://doi.org/10.1016/S2214-109X(18)30451-0.

Colaizy, T.T., Carlson, S., Saftlas, A.F., Morriss Jr., F.H., 2012. Growth in VLBW infants fed predominantly fortified maternal and donor human milk diets: a retrospective cohort study. BMC Pediatr. 12, 124. https://doi.org/10.1186/1471-2431-12-124.

Colaizy, T.T., Bartick, M.C., Jegier, B.J., Green, B.D., Reinhold, A.G., Schaefer, A.J., Bogen, D.L., Schwarz, E.B., Stuebe, A.M., 2016. Impact of optimized breastfeeding on the costs of necrotizing enterocolitis in extremely low birth weight infants. J. Pediatr. 175, 100-105. https://doi.org/10.1016/j.jpeds.2016.03.040. e2.

Cortez, J., Makker, K., Kraemer, D.F., Neu, J., Sharma, R., Hudak, M.L., 2018. Maternal milk feedings reduce sepsis, necrotizing enterocolitis and improve outcomes of premature infants. J. Perinatol. 38 (1), 71-74. https://doi.org/10.1038/jp.2017.149.

Cunha, L.R., Costa, T.H., Caldas, E.D., 2013. Mercury concentration in breast milk and infant exposure assessment during the first 90 days of lactation in a Midwestern region of Brazil. Biol. Trace Elem. Res. 151 (1), 30-37. https://doi.org/10.1007/ s12011-012-9542-2. 
Dutta, S., Singh, B., Chessell, L., Wilson, J., Janes, M., McDonald, K., Shahid, S., Gardner, V.A., Hjartarson, A., Purcha, M., Watson, J., de Boer, C., Gaal, B., Fusch, C., 2015. Guidelines for feeding very low birth weight infants. Nutrients 7 (1), 423-442. https://doi.org/10.3390/nu7010423.

Fängström, B., Moore, S., Nermell, B., Kuenstl, L., Goessler, W., Grandér, M., Kabir, I., Palm, B., Arifeen, S.E., Vahter, M., 2008. Breast-feeding protects against arsenic exposure in Bangladeshi infants. Environ. Health Perspect. 116 (7), 963-969. https:// doi.org/10.1289/ehp.11094.

Finch, C.W., 2015. Review of trace mineral requirements for preterm infants: what are the current recommendations for clinical practice? Nutr. Clin. Pract. 30 (1), 44-58. https://doi.org/10.1177/0884533614563353.

García-Esquinas, E., Pérez-Gómez, B., Fernández, M.A., Pérez-Meixeira, A.M., Gil, E., de Paz, C., Iriso, A., Sanz, J.C., Astray, J., Cisneros, M., de Santos, A., Asensio, A., GarcíaSagredo, J.M., García, J.F., Vioque, J., Pollán, M., López-Abente, G., González, M.J., Martínez, M., Bohigas, P.A., Pastor, R., Aragonés, N., 2011. Mercury, lead and cadmium in human milk in relation to diet, lifestyle habits and sociodemographic variables in Madrid (Spain). Chemosphere 85, 268-276. https://doi.org/10.1016/j chemosphere.2011.05.029.

Gil, F., Hernández, A.F., 2015. Toxicological importance of human biomonitoring of metallic and metalloid elements in different biological samples. Food Chem. Toxicol. 80, 287-297. https://doi.org/10.1016/j.fct.2015.03.025.

Harding, J.E., Cormack, B.E., Alexander, T., Alsweiler, J.M., Bloomfield, F.H., 2017. Advances in nutrition of the newborn infant. Lancet 389 (10079), 1660-1668. https://doi.org/10.1016/S0140-6736(17)30552-4.

Heyer, D.B., Meredith, R.M., 2017. Environmental toxicology: sensitive periods of development and neurodevelopmental disorders. Neurotoxicology 58, 23-41. https:// doi.org/10.1016/j.neuro.2016.10.017.

Jagodic, M., Potočnik, D., Snoj Tratnik, J., Mazej, D., Pavlin, M., Trdin, A., Eftimov, T., Kononenko, L., Ogrinc, N., Horvat, M., 2020. Selected elements and fatty acid composition in human milk as indicators of seafood dietary habits. Environ. Res. 180, 108820. https://doi.org/10.1016/j.envres.2019.108820.

Khanjani, N., Jafari, M., Ahmadi Mousavi, E., 2018. Breast milk contamination with lead and cadmium and its related factors in Kerman, Iran. J Environ Health Sci Eng 16 (2), 323-335. https://doi.org/10.1007/s40201-018-0320-8.

Kılıç Altun, S., Dinç, H., Temamoğulları, F.K., Paksoy, N., 2018. Analyses of essential elements and heavy metals by using ICP-MS in maternal breast milk from Şanlıurfa, Turkey. Int J Anal Chem 2018, 1784073. https://doi.org/10.1155/2018/1784073.

Klein, L.D., Breakey, A.A., Scelza, B., Valeggia, C., Jasienska, G., Hinde, K., 2017. Concentrations of trace elements in human milk: comparisons among women in Argentina, Namibia, Poland, and the United States. PloS One 12 (8), e0183367. https://doi.org/10.1371/journal.pone.0183367.

Koo, W., Tice, H., 2018. Human milk fortifiers do not meet the current recommendation for nutrients in very low birth weight infants. JPEN - J. Parenter. Enter. Nutr. 42 (4), 813-820. https://doi.org/10.1177/0148607117713202.

Kumar, R.K., Singhal, A., Vaidya, U., Banerjee, S., Anwar, F., Rao, S., 2017. Optimizing nutrition in preterm low birth weight infants-consensus summary. Front Nutr 4, 20. https://doi.org/10.3389/fnut.2017.00020.

Leotsinidis, M., Alexopoulos, A., Kostopoulou-Farri, E., 2005. Toxic and essential trace elements in human milk from Greek lactating women: association with dietary habits and other factors. Chemosphere 61 (2), 238-247.

Letinić, J.G., Sarić, M.M., Piasek, M., Jurasović, J., Varnai, V.M., Grgec, A.S., Orct, T., 2016. Use of human milk in the assessment of toxic metal exposure and essential element status in breastfeeding women and their infants in coastal Croatia. J. Trace Elem. Med. Biol. 38, 117-125. https://doi.org/10.1016/j.jtemb.2016.08.002.

Li, C., Solomons, N.W., Scott, M.E., Koski, K.G., 2016. Minerals and trace elements in human breast milk are associated with Guatemalan infant anthropometric outcomes within the first 6 months. J. Nutr. 146 (10), 2067-2074.

Marques, R.C., Moreira, M.F., Bernardi, J.V., Dórea, J.G., 2013. Breast milk lead concentrations of mothers living near tin smelters. Bull. Environ. Contam. Toxicol. 91 (5), 549-554. https://doi.org/10.1007/s00128-013-1093-5.

Martínez, M.A., Castro, I., Rovira, J., Ares, S., Rodríguez, J.M., Cunha, S.C., Casal, S., Fernandes, J.O., Schuhmacher, M., Nadal, M., 2019. Early life intake of major trace elements, bisphenol A, tetrabromobisphenol A and fatty acids: comparing human milk and commercial infant formulas. Environ. Res. 169, 246-255. https://doi.org/ 10.1016/j.envres.2018.11.017.

McCarthy, E.K., Dempsey, E.M., Kiely, M.E., 2019. Iron supplementation in preterm and low-birth-weight infants: a systematic review of intervention studies. Nutr. Rev. 77 (12), 865-877. https://doi.org/10.1093/nutrit/nuz051.

Mohd-Taufek, N., Cartwright, D., Davies, M., Hewavitharana, A.K., Koorts, P., McConachy, H., Shaw, P.N., Sumner, R., Whitfield, K., 2016. The effect of pasteurization on trace elements in donor breast milk. J. Perinatol. 36 (10), 897-900. https://doi.org/10.1038/jp.2016.88.

Moreno-Fernandez, J., Ochoa, J.J., Latunde-Dada, G.O., Diaz-Castro, J., 2019. Iron deficiency and iron homeostasis in low birth weight preterm infants: a systematic review. Nutrients 11 (5), E1090. https://doi.org/10.3390/nu11051090. pii.

Oliveira, M.M., Aragon, D.C., Bomfim, V.S., Trevilato, T.M.B., Alves, L.G., Heck, A.R., Martinez, F.E., Camelo, J.S., 2019. Development of a human milk concentrate with human milk lyophilizate for feeding very low birth weight preterm infants: a preclinical experimental study. PloS One 14 (2), e0210999. https://doi.org/10.1371 journal.pone.0210999.

Pajewska-Szmyt, M., Sinkiewicz-Darol, E., Gadzała-Kopciuch, R., 2019. The impact of environmental pollution on the quality of mother's milk. Environ. Sci. Pollut. Res. Int 26 (8), 7405-7427. https://doi.org/10.1007/s11356-019-04141-1.

Patra, K., Hamilton, M., Johnson, T.J., Greene, M., Dabrowski, E., Meier, P.P., Patel, A.L., 2017. NICU human milk dose and 20-Month neurodevelopmental outcome in very low birth weight infants. Neonatology 112 (4), 330-336. https://doi.org/10.1159/ 000475834.

Qi, J., Lai, Y., Liang, C., Yan, S., Huang, K., Pan, W., Feng, L.1, Jiang, L., Zhu, P., Hao, J., Tong, S., Tao, F., 2019. Prenatal thallium exposure and poor growth in early childhood: a prospective birth cohort study. Environ. Int. 123, 224-230. https://doi.org/ 10.1016/j.envint.2018.12.005.

Rebelo, F.M., Caldas, E.D., 2016. Arsenic, lead, mercury and cadmium: toxicity, levels in breast milk and the risks for breastfed infants. Environ. Res. 151, 671-688. https:// doi.org/10.1016/j.envres.2016.08.027.

Sabatier, M., Garcia-Rodenas, C.L., Castro, C.A., Kastenmayer, P., Vigo, M., Dubascoux, S., Andrey, D., Nicolas, M., Payot, J.R., Bordier, V., Thakkar, S.K., Beauport, L., Tolsa, J.F., Fumeaux, C.J.F., Affolter, M., 2019. Longitudinal changes of mineral concentrations in preterm and term human milk from lactating Swiss women. Nutrients 11 (8). https://doi.org/10.3390/nu11081855.

Salmani, M.H., Mozaffari-Khosravi, H., Rezaei, Z., 2016. The Nickel concentration in breast milk during the first $\mathrm{m}$ month of lactation in Yazd, center of Iran. Biol. Trace Elem. Res. 174 (1), 65-70.

Samiee, F., Vahidinia, A., Taravati Javad, M., Leili, M., 2019. Exposure to heavy metals released to the environment through breastfeeding: a probabilistic risk estimation. Sci. Total Environ. 650 (Pt 2), 3075-3083. https://doi.org/10.1016/j.scitotenv.2018. 10.059 .

Sammallahti, S., Kajantie, E., Matinolli, H.M., Pyhälä, R., Lahti, J., Heinonen, K., Lahti, M., Pesonen, A.K., Eriksson, J.G., Hovi, P., Järvenpää, A.L., Andersson, S., Raikkonen, K., 2017. Nutrition after preterm birth and adult neurocognitive outcomes. PloS One 12 (9), e0185632. https://doi.org/10.1371/journal.pone.0185632.

Snoj Tratnik, J., Falnoga, I., Mazej, D., Kocman, D., Fajon, V., Jagodic, M., Stajnko, A., Trdin, A., Šlejkovec, Z., Jeran, Z., Osredkar, J., Sešek-Briški, A., Krsnik, M., Kobal, A.B., Kononenko, L., Horvat, M., 2019. Results of the first national human biomonitoring in Slovenia: trace elements in men and lactating women, predictors of exposure and reference values. Int. J. Hyg Environ. Health 222 (3), 563-582. https:// doi.org/10.1016/j.ijheh.2019.02.008.

Taravati Javad, M., Vahidinia, A., Samiee, F., Elaridi, J., Leili, M., Faradmal, J., Rahmani, A., 2018. Analysis of aluminum, minerals and trace elements in the milk samples from lactating mothers in Hamadan, Iran. J. Trace Elem. Med. Biol. 50, 8-15. https:// doi.org/10.1016/j.jtemb.2018.05.016.

Tindell, R., Tipple, T., 2018. Selenium: implications for outcomes in extremely preterm infants. J. Perinatol. 38 (3), 197-202. https://doi.org/10.1038/s41372-017-0033-3.

Vahidinia, A., Samiee, F., Faradmal, J., Rahmani, A., Taravati Javad, M., Leili, M., 2019. Mercury, Lead, Cadmium, and Barium levels in human breast milk and factors affecting their concentrations in Hamadan, Iran. Biol. Trace Elem. Res. 187 (1), 32-40. https://doi.org/10.1007/s12011-018-1355-5.

Valentine, C.J., Morrow, G., Reisinger, A., Dingess, K.A., Morrow, A.L., Rogers, L.K., 2017. Lactational stage of pasteurized human donor milk contributes to nutrient limitations for infants. Nutrients 9 (3), E302. https://doi.org/10.3390/nu9030302 pii.

Walker, A., 2010. Breast milk as the gold standard for protective nutrients. J. Pediatr. 156 (2 Suppl. 1), S3-S7. https://doi.org/10.1016/j.jpeds.2009.11.021.

Weidenhamer, J.D., Fitzpatrick, M.P., Biro, A.M., Kobunski, P.A., Hudson, M.R., Corbin, R.W., Gottesfeld, P., 2017. Metal exposures from aluminum cookware: an unrecognized public health risk in developing countries. Sci. Total Environ. 579, 805-813. https://doi.org/10.1016/j.scitotenv.2016.11.023.

WHO/IAEA, 1989. Minor and Trace Elements in Breast Milk: Report of a Joint WHO/ IAEA Collaborative Study, vols. 1-15. World Health Organization, pp. 118-119.

WHO, 2008. World Health Organization (WHO)- Guidance for Identifying Populations at Risk from Mercury Exposure. Issued by UNEP DTIE Chemicals Branch and WHO Department of Food Safety, Zoonoses and Foodborne Diseases, Geneva, Switzerland.

Wu, M., Shu, Y., Song, L., Liu, B., Zhang, L., Wang, L., Liu, Y., Bi, J., Xiong, C., Cao, Z., Xu, S., Xia, W., Li, Y., Wang, Y., 2019. Prenatal exposure to thallium is associated with decreased mitochondrial DNA copy number in newborns: evidence from a birth cohort study. Environ. Int. 129, 470-477. https://doi.org/10.1016/j.envint.2019.05. 053. 


\section{DISCUSSÃO}

A presente tese comprova a possibilidade de formulação do LH concentrado pasteurizado a partir de um método direto, simples e pouco oneroso de liofilização do LH maduro doado e sua utilização como aditivo natural do próprio LH, seguido de etapa final de pasteurização. Além disso, o LH concentrado pasteurizado apresentou segurança microbiológica, osmolalidade aceitável e o aumento significativo da concentração de macro e micronutrientes essenciais, o que torna esse produto uma alternativa viável e segura para o adequado suporte nutricional do RNMBP durante o período de internação na UTIN. Sendo assim, consideramos como mérito desse estudo a possibilidade de formulação de um LH concentrado pasteurizado com alta qualidade nutricional e comprovada segurança microbiológica a partir de um método pouco oneroso e isento de viés ético, visto que o LH utilizado foi proveniente de doações da produção excedente de leite materno por doadoras recrutadas pelo BLH.

A primeira publicação científica, apresentada no capítulo 1 desta tese, relata os métodos empregados na formulação do LH concentrado assim como a determinação do valor energético, da concentração de macro e micronutrientes essenciais, da osmolalidade, além das análises da segurança microbiológica e da estabilidade nutricional e microbiológica após 3 e 6 meses de congelamento. A comprovação e quantificação da concentração final do LH após acréscimo do LH liofilizado foi obtida mediante comparação entre o LH linha de base e o LH concentrado ambos pasteurizados. Assim, foi possível detectar o aumento significativo do valor energético e da concentração de macro e micronutrientes essenciais tais como proteína, carboidratos, lipídios totais, $\mathrm{Ca}, \mathrm{Mg}, \mathrm{Na}, \mathrm{K}, \mathrm{Cu}, \mathrm{Zn}$ e $\mathrm{P}$ no LH concentrado. A segurança microbiológica foi comprovada e se manteve por até 6 meses de armazenamento congelado. A estabilidade nutricional do LH concentrado foi estatisticamente parcial após 3 e 6 meses de armazenamento congelado $\left(-20^{\circ} \mathrm{C}\right)$, porém tais alterações são consideradas clinicamente pouco significantes.

O capítulo 2 desta tese apresenta a publicação científica referente a análise de elementos essenciais ( $\mathrm{Cr}, \mathrm{Fe}, \mathrm{Mn}$ e $\mathrm{Se}$ ) e potencialmente tóxicos (Al, As, $\mathrm{Cd}, \mathrm{Pb}, \mathrm{Sn}, \mathrm{Hg}, \mathrm{Ni}$ e $\mathrm{Tl}$ ) tanto no LH concentrado quanto no LH linha de base com o propósito de complementar o estudo anterior descrito no capítulo 1. Assim, foi possível comprovar o aumento significativo apenas dos micronutrientes essenciais $\mathrm{Mn}$ e Se no $\mathrm{LH}$ concentrado, o que reforça a viabilidade e segurança do LH concentrado a ser utilizado no suporte nutricional do RNMBP durante o período de internação na UTIN. 
A presente tese também demonstrou a possibilidade de implantação do método de liofilização e desenvolvimento do LH concentrado na rotina da $\mathrm{BLH}-\mathrm{BR}$, reforçando assim a utilização do LH maduro doado liofilizado como alternativa promissora para o desuso dos aditivos comerciais utilizados nas UTINs brasileiras.

Atualmente, os aditivos comerciais específicos para LH mais utilizados na prática clínica neonatal dos hospitais públicos brasileiros são o FM-85® (Nestlé®) e o Enfamil HMF® (Mead Johnson ${ }^{\circledR}$ ), os quais têm como matéria prima o leite de vaca enriquecido com macro e micronutrientes essenciais (Arslanoglu et al., 2019; Brown et al., 2016; Thomaz et al., 2012).

Diversos autores defendem a necessidade de fortificação do LH com aditivos específicos com o objetivo de aumentar o conteúdo de nutrientes e, com isso, tentar atender as necessidades nutricionais especiais do RNMBP e garantir o adequado crescimento e desenvolvimento desse recém-nascido durante o período de internação na UTIN (Colaizy et al., 2012; Harding et al., 2017; Kumar, Yadav, 2019; Raiten; Steiber; Hand, 2016; Schanler et al., 2018). Entretanto, estudos relatam que a exposição precoce à proteína do leite de vaca, considerada heteróloga para o organismo humano, está associada ao déficit de crescimento pósnatal, à maior intolerância alimentar, ao esvaziamento gástrico lento, ao tempo prolongado de nutrição parenteral, ao aumento de morbidades tais como EN e sepse e, consequentemente, maior mortalidade neonatal (Assad; Elliott; Abraham, 2016; Ganapathy; Hay; Kim, 2012; Hair et al., 2018; Perrella et al., 2015; Sullivan et al, 2010). Além disso, recente e extenso estudo destaca que tais aditivos comerciais de LH não atendem satisfatoriamente as necessidades nutricionais do RNMBP visto que muitos micronutrientes essenciais estão ausentes ou presentes em quantidades bastante inadequadas (Koo; Tice, 2018).

Diante do dilema da utilização de aditivos à base de proteína do leite de vaca, técnicas avançadas de lacto-engenharia permitiram o desenvolvimento de fortificantes líquido e cremoso derivados do próprio $\mathrm{LH}$, os quais foram associados à desfechos satisfatórios tais como a maior velocidade de ganho de peso e de crescimento, redução do tempo de internação hospitalar, redução de morbidade por sepse e EN, além de menor mortalidade do RNMBP (Abrams et al., 2014; Cristofalo et al., 2013; Hair et al., 2014; Hair et al., 2016a; Hair et al., 2016b; Sullivan et al, 2010).

O estudo inicial referente ao desenvolvimento do método para obtenção do LH concentrado foi publicado na década de 80 e, desde então, vem sendo continuamente explorado e aprimorado. O método original de concentração do LH baseia-se na centrifugação desse leite 
para obtenção de um creme, seguido de extração da lactose por diálise simples e, finalmente, liofilização (Lucas et al., 1980).

Inspirados no estudo anterior, pesquisadores brasileiros comprovaram a possibilidade de formulação de dois aditivos, líquido e em pó, derivados exclusivamente do LH por meio dos processos de retirada da gordura, evaporação para concentração dos nutrientes e remoção da lactose e, por fim, liofilização (Thomaz et al., 2012). Anos depois, o mesmo grupo de pesquisa publicou o aprimoramento da técnica de desenvolvimento do suplemento homólogo de LH a partir da remoção da lactose e liofilização, o que minimizou etapas de manipulação, mudanças de temperatura e do estado físico do leite com o propósito de melhorar a conservação dos nutrientes (Grance et al., 2015). Ainda assim, o processamento e a preparação dos aditivos derivados do LH demandam uma avançada tecnologia e a extensa manipulação do leite para a obtenção da concentração dos componentes nutricionais e fatores bioativos.

Atualmente, a empresa privada norte americana denominada Prolacta Bioscience ${ }^{\circledR}$ é a única que produz e comercializa o total de seis modalidades de aditivos à base de LH para diferentes volumes e valores calóricos finais do LH fortificado, cujas informação completas estão disponíveis em https://www.prolacta.com. Tais produtos foram clinicamente testados em diversos estudos: randomizado controlado, observacional, comparativo e retrospectivo. Tais autores comprovaram os desfechos satisfatórios de redução do tempo de internação hospitalar, redução de morbidades tais como EN cirúrgica e não cirúrgica, sepse tardia, displasia bronco pulmonar e retinopatia da prematuridade, além da promoção de maior ganho de peso, melhor crescimento longitudinal e maior ganho de circunferência da cabeça dos RNMBP (Cristofalo et al., 2013; Hair et al., 2013; Hair et al., 2014; Hair et al., 2016a; Hair et al., 2016b; Huston et al., 2018; Sullivan et al, 2010).

Os benefícios associados à utilização dos aditivos produzidos pela empresa Prolacta Bioscience ${ }^{\circledR}$ são promissores, entretanto, consideramos inviável a utilização de tais produtos pelas UTINs brasileiras devido ao custo elevado e, principalmente, pelas questões éticas envolvidas na produção e comercialização desses aditivos provenientes de substância humana (Ganapathy; Hay; Kim, 2012). No Brasil, de acordo com o parágrafo $4^{\circ}$ do artigo 199 da Constituição da República Federativa de 1988, é vedado todo tipo de comercialização de substâncias humanas como o leite materno, fato que talvez inviabilizasse legalmente a utilização dos aditivos da Prolacta Bioscience ${ }^{\circledR}$ (Brasil, 2016). Sendo assim, consideramos como mérito dos estudos apresentados nesta tese a possibilidade de formulação de um LH concentrado pasteurizado a partir de um método pouco oneroso, isento de viés ético e que, após 
incorporado na rotina da rBLH-BR, disponibilizará um produto não monetizado (sem fins lucrativos) com alta qualidade nutricional e segurança microbiológica para ser utilizado como recurso nutricional para o RNMBP durante o período de internação na UTIN. Importante destacar que a Resolução RDC/Anvisa nº 171 de 2006 pró́be a comercialização dos produtos coletados, processados e distribuídos pelo BLH e Posto de Coleta de LH (Brasil, 2006).

A alta qualidade nutricional e a segurança microbiológica do LH concentrado desenvolvido no presente estudo foi comprovada a partir de vários métodos de análise. Inicialmente, foi importante a avaliação da osmolalidade do leite após o processo da concentração visto que alguns autores sugerem que a alta osmolalidade da nutrição enteral pode estar associada à eventos adversos tais como disfunções gastrointestinais e EN em prematuros (Book et al., 1975; Pearson; Johnson; Leaf, 2013).

As recentes diretrizes referentes à alimentação enteral do recém-nascido pré-termo não incluem um nível superior recomendado para a osmolalidade (Agostoni et al., 2010; Koletzko; Poindexter; Uauy, 2014; Kumar et al., 2017; Raiten; Steiber; Hand, 2016). Além disso, atual revisão sistemática aponta que não há evidências consistentes de que a osmolalidade da alimentação enteral na faixa de 300 a $500 \mathrm{mOsm} / \mathrm{kg} \mathrm{H}_{2} \mathrm{O}$ esteja associada à sintomas gastrointestinais adversos em neonatos (Ellis et al., 2019). Entretanto, apesar de ultrapassada, a recomendação vigente da Academia Americana de Pediatria (AAP) orienta que a osmolalidade não exceda $450 \mathrm{mOsm} / \mathrm{kg} \mathrm{H}_{2} \mathrm{O}$ (ou, aproximadamente, a osmolaridade de $400 \mathrm{mOsm} / \mathrm{L}$ ) para o leite materno ou fórmulas infantis (Barness et al., 1976).

A osmolalidade natural do leite materno é de aproximadamente $300 \mathrm{mOsm} / \mathrm{kg} \mathrm{H}_{2} \mathrm{O}$, entretanto, o acréscimo de aditivos específicos de LH à base de proteína do leite de vaca proporciona um aumento para níveis superiores a $400 \mathrm{mOsm} / \mathrm{kg} \mathrm{H}_{2} \mathrm{O}$ (Chandran et al., 2017; Kreissl et al., 2013; Rochow et al., 2013; Rosas et al., 2016).

O presente estudo detectou valores médios de osmolalidade no LH linha de base (289.48 $\mathrm{mOsm} / \mathrm{kg} \mathrm{H}_{2} \mathrm{O}$ ) compatível com a osmolalidade natural do leite materno, assim como o LH concentrado (452.12 mOsm/ $/ \mathrm{kg} \mathrm{H}_{2} \mathrm{O}$ ) apresentou osmolalidade aceitável e semelhante ao leite com adição de aditivos comerciais à base de proteína do leite de vaca, como citado acima e observado na Tabela 2 do capítulo 1 desta tese.

Estudos anteriores referentes aos métodos de concentração do LH apostaram na remoção da lactose e posterior liofilização do LH com objetivo de ajustar a osmolalidade do produto final aos valores considerados aceitáveis pela AAP (Grance et al., 2015; Lucas et al., 1980; Thomaz et al., 2012). Entretanto, tais autores detectaram valores de osmolalidade (335- 
$438 \mathrm{mOsm} / \mathrm{kg} \mathrm{H}_{2} \mathrm{O}$ ) semelhantes aos nossos (Grance et al., 2015). Diante disso, é importante destacar que o método simplificado proposto pelo presente estudo, ou seja, a mínima manipulação do leite por meio da liofilização direta sem redução da lactose, possibilitou a formulação do LH concentrado com valor aceitável de osmolalidade e possível de ser tolerada pelo RNMBP. Além disso, tais valores de osmolalidade não apresentaram um aumento significativo durante os períodos de 3 e 6 meses de armazenamento $\left(-20^{\circ} \mathrm{C}\right)$, fato sustentado por outro estudo que não detectou o aumento da osmolalidade do leite materno cru armazenado congelado $\left(-20^{\circ} \mathrm{C}\right)$ por até 9 meses (Ahrabi et al., 2016).

A segurança microbiológica é o principal critério a ser cumprido no que diz respeito a alimentação enteral fornecida aos recém-nascidos pré-termo. Sendo assim, para garantir a segurança microbiológica do LH concentrado desenvolvido neste estudo foi aplicado o tratamento térmico de pasteurização com objetivo de inativar termicamente agentes virais e bacterianos a partir de uma fase inicial de aquecimento rápido, seguido da manutenção da temperatura de $62,5^{\circ} \mathrm{C}$ por 30 minutos e, finalmente, uma fase final de resfriamento rápido ( $\leq$ $5^{\circ} \mathrm{C}$ ) (Capriati et al., 2019; Moro et al., 2019; Peila et al., 2016; Wesolowska et al., 2019). Sabese que tal tratamento térmico reduz parcialmente as concentrações de determinadas proteínas específicas de ação imunológica como imunoglobulinas ( $\operatorname{Ig} \mathrm{A}, \operatorname{IgM}$ e $\operatorname{IgG}$ ), lactoferrina, lisozima e lactoperoxidase (Buffin et al., 2018; Peila et al., 2016; Picaud; Buffin, 2017; Sousa; Delgadillo; Saraiva, 2014). Entretanto, o método de pasteurização não afeta negativamente importantes componentes nutricionais e bioativos do LH tais como o conteúdo de determinados ácidos graxos essenciais e vitaminas lipossolúveis extremamente relevantes para o desenvolvimento do sistema nervoso central de recém-nascidos (Peila et al., 2016; Picaud; Buffin, 2017). Portanto, a pasteurização é o procedimento recomendado por diretrizes nacionais e internacionais de BLH para o garantir a qualidade nutricional e a segurança microbiológica do LH doado oferecido ao recém-nascido, fato que corrobora o método aplicado no presente estudo (Brasil, 2006, 2008; Moro et al., 2019; Peila et al., 2016). Após os testes, as análises de segurança microbiológica realizadas nas amostras no período imediato e após o armazenamento $\left(-20^{\circ} \mathrm{C}\right)$ confirmaram a adequada qualidade sanitária do produto por até 6 meses.

Os efeitos do processo de concentração do LH podem ser observados nas publicações referentes aos capítulos 1 e 2 desta tese. É importante destacar que o valor energético e a concentração de macro (proteína, carboidrato, lipídios totais, sólidos totais, proteína verdadeira) e micronutrientes ( $\mathrm{Ca}, \mathrm{Mg}, \mathrm{Na}, \mathrm{K}, \mathrm{Cu}, \mathrm{Zn}, \mathrm{P}, \mathrm{Mn}$ e $\mathrm{Se}$ ) essenciais avaliados apresentaram um aumento estatisticamente significativo no LH concentrado quando comparado com o LH linha 
de base, exceto o conteúdo de $\mathrm{Cr}$ e Fe. Além disso, é importante destacar que não houve aumento estatisticamente significativo na concentração de elementos potencialmente tóxicos (Al, As, $\mathrm{Cd}, \mathrm{Pb}, \mathrm{Sn}, \mathrm{Hg}, \mathrm{Ni}$ e $\mathrm{Tl}$ ) no $\mathrm{LH}$ concentrado, fato possivelmente justificado pela favorável baixa concentração de tais elementos no LH linha de base. A literatura científica referente ao procedimento de liofilização sustenta nossos resultados visto que tal método preserva importantes propriedades nutricionais e bioativas do LH tais como ácidos graxos essenciais e imunoglobulinas (Albarrán et al., 2017; Cortez; Soria, 2016; Hahn et al., 2019; Lozano et al., 2014). Sendo assim, comprovamos a possibilidade de concentração do LH por meio do processo de liofilização direta seguida de reconstituição em mesmo leite (LH linha de base) e, portanto, a formulação de um produto à base de LH exclusivo seguro do ponto de vista microbiológico e com alta qualidade nutricional.

$\mathrm{O}$ armazenamento do $\mathrm{LH}$ concentrado congelado $\left(-20^{\circ} \mathrm{C}\right)$ por 3 e 6 meses proporcionou efeitos diversos na concentração de macro e micronutrientes essenciais, como descrito no capítulo 1 desta tese. Primeiramente, foi detectada uma redução do valor energético e nas concentrações de lipídios totais e Cu no LH concentrado após o armazenamento congelado. Além disso, as amostras de LH concentrado apresentaram um ligeiro aumento nas concentrações de $\mathrm{Ca}, \mathrm{Mg}, \mathrm{K}, \mathrm{P}$ e Zn após congelamento. Entretanto, é importante destacar que as concentrações de carboidrato e proteínas se mantiveram estáveis por 3 e 6 meses de armazenamento a $-20^{\circ} \mathrm{C}$.

Estudo recente valida nossos resultados pois comprova que o armazenamento do LH congelado $\left(-20^{\circ} \mathrm{C}\right)$ por até 9 meses não afetou seu conteúdo de proteínas totais e imunoativas (lactoferrina e IgA secretora), o que sugere a preservação de importantes componentes nutricionais e imunológicos do leite materno (Ahrabi et al., 2016). Entretanto, embora alguns autores reportem o aumento significativo de $13.4 \%$ na concentração de proteínas no LH pasteurizado após 8 meses congelado $\left(-20^{\circ} \mathrm{C}\right)$, estudo recente não encontrou alterações nos teores de proteínas no leite materno após 2 meses em mesma condição de armazenamento (Kim et al., 2019; Waard et al., 2018). Além disso, estudo destaca o não comprometimento do conteúdo energético e dos teores de gordura e carboidrato no LH pasteurizado durante o período de 8 meses de armazenamento congelado $\left(-20^{\circ} \mathrm{C}\right)$ (Waard et al., 2018). Porém, semelhantes aos nossos resultados, estudos relatam que o armazenamento sob congelamento $\left(-20^{\circ} \mathrm{C}\right)$ por 3 e 6 meses reduziu discretamente o conteúdo energético e o teor de gordura do LH pasteurizado enquanto o conteúdo de proteínas e carboidratos permaneceu estável (García-Lara et al., 2012; García-Lara et al., 2013; Tanriverdi et al., 2019). Sendo assim, tal variabilidade das 
concentrações de macro e micronutrientes sugere uma estabilidade estatisticamente parcial do LH concentrado armazenado congelado $\left(-20^{\circ} \mathrm{C}\right)$ porém clinicamente pouco significativa.

Finalmente, atendendo ao último objetivo específico desta tese, foi possível avaliar se as concentrações de macro e micronutrientes essenciais presentes no $\mathrm{LH}$ concentrado pasteurizado atendem as necessidades nutricionais específicas do recém-nascido pré-termo, de acordo com as recomendações nutricionais vigentes. Sendo assim, as quantidades de carboidratos $(11.5 \mathrm{~g})$, lipídios totais $(5.0 \mathrm{~g}), \mathrm{K}(126.8 \mathrm{mg}), \mathrm{Cr}(0.7 \mu \mathrm{g})$ e Se $(1.8 \mu \mathrm{g})$ presentes no LH concentrado (média expressa por $100 \mathrm{kcal}$ ) atendem plenamente às recomendações nutricionais estabelecidas pela European Society of Pediatric Gastroenterology, Hepatology, and Nutrition e pela Life Sciences Research Office, referentes à alimentação enteral adequada do recém-nascido pré-termo (Agostoni et al., 2010; Tudehope et al., 2013).

Diversos estudos relatam que a ingestão adequada de energia e lipídios promove melhor ganho de peso, crescimento, maturação cerebral e neurodesenvolvimento do recém-nascido pré-termo (Cormack et al., 2020; Coviello et al., 2018; Hiltunen et al., 2018; Schneider et al., 2018; Westin et al., 2018). Além disso, recente estudo revela que o LH produzido pela mãe do recém-nascido pré-termo apresenta maior conteúdo de energia e de teor de lipídios durante as primeiras semanas após o parto, comparado ao leite materno produzido pela mãe do recémnascido a termo (Fischer Fumeaux et al., 2019; Thakkar et al., 2019). Sendo assim, tal informação sugere uma possível adequação natural do LH concentrado desenvolvido frente às necessidades nutricionais do prematuro visto ser um produto adequado quanto ao conteúdo de carboidratos, lipídios e, consequentemente, energia. Diante de tais fatos, os resultados desta tese sustentam a viabilidade nutricional do LH concentrado desenvolvido como proposta para o adequado suporte nutricional do RNMBP. Entretanto, é importante relatar que os demais nutrientes essenciais avaliados atendem parcialmente as recomendações de ingestão enteral para o recém-nascido pré-termo (Agostoni et al., 2010; Tudehope et al., 2013).

As concentrações de proteínas e de determinados micronutrientes essenciais $(\mathrm{Ca}, \mathrm{Mg}$, $\mathrm{Na}, \mathrm{P}, \mathrm{Cu}, \mathrm{Zn}, \mathrm{Fe}$ e $\mathrm{Mn}$ ) no $\mathrm{LH}$ concentrado, as quais atendem parcialmente as necessidades nutricionais do recém-nascido pré-termo, podem gerar preocupações e, por isso, justificam o monitoramento sérico e a necessidade de suplementação isolada.

O teor de proteínas no LH concentrado $(1.68-2.02 \mathrm{~g} / 100 \mathrm{kcal})$ está aquém das recomendações nutricionais vigentes para o recém-nascido pré-termo (Agostoni et al., 2010; Tudehope et al., 2013). Entretanto, o LH pasteurizado e fortificado com FM-85® (Nestlé®) na diluição de 4\%, o aditivo comercial comumente utilizado nas UTIs brasileiras, fornece apenas 
$3.7 \mathrm{~g}$ de proteína (média expressa por $100 \mathrm{kcal}$ ) e pode não atender plenamente as necessidades nutricionais de proteínas (3.2-4.1g/100kcal) do RNMBP (Agostoni et al., 2010; Thomaz et al., 2012). Corroborando com este alerta, autores afirmam que o LH fortificado com FM-85® (Nestlé®) não atende a alta necessidade nutricional tanto de proteínas quanto de $\mathrm{Ca}, \mathrm{P}$ e $\mathrm{Mg}$ do recém-nascido extremamente prematuro (Corvaglia et al., 2010; Loui et al., 2002). Além disso, parte deste montante de proteínas fornecido pelo LH fortificado com FM-85® (Nestlé®) é composto por proteína heteróloga proveniente do leite de vaca comprovadamente maléfica para o recém-nascido pré-termo (Arslanoglu et al., 2019; Brown et al., 2016).

Estudos atuais sugerem que a ingestão de proteínas de alto valor nutricional e bioativo, naturalmente presentes no LH, quando associadas à ingestão adequada de energia resultam no crescimento de melhor qualidade do RNMBP constatado pela maior taxa de massa corporal livre de gordura, que pode gerar melhores desfechos metabólicos no futuro para o prematuro (Cerasani et al., 2020; Gianni; Roggero; Mosca, 2019; Morlacchi et al., 2018). Além disso, proteínas bioativas (ex.: proteínas antimicrobianas, citocinas, lactoferrina, lisozimas e imunoglobulinas) presentes no LH desempenham um papel crucial na maturação do sistema imunológico e na proteção do recém-nascido pré-termo proporcionando a redução da incidência de morbidades relacionadas ao sistema imune (ex.: EN, alergias, displasia bronco pulmonar e retinopatia da prematuridade) desse prematuro (Lewis et al., 2017; Lönnerdal, 2017). É interessante observar que o LH fortificado com os produtos da Prolacta Bioscience ${ }^{\circledR}$ (Prolact+ 4, 6, 8 e 10), aditivo comercial à base exclusivamente de LH, apresentam concentrações (expressa por $100 \mathrm{kcal}$ ) de proteínas (2.3-3.3g), carboidratos (8.0-9.9g), Na (53.0-61.4mg), K

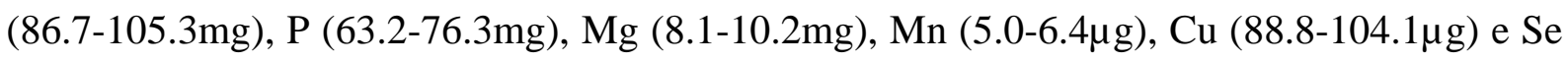

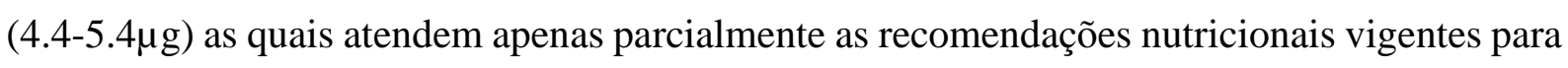
o recém-nascido pré-termo, quando referente à adição do fortificante em LH maduro de mães de recém-nascidos a termo segundo os dados disponíveis em https://www.prolacta.com (Agostoni et al., 2010; Tudehope et al., 2013). Além disso, é importante destacar que tais produtos da Prolacta Bioscience ${ }^{\circledR}$ não atendem as recomendações para $\mathrm{Zn}$ e Fe, assim como o LH concentrado apresentado nesta tese (Agostoni et al., 2010; Tudehope et al., 2013). Apesar de tais incompatibilidades frente às recomendações nutricionais citadas, diversos estudos clínicos randomizados e controlados comprovam relevantes desfechos favoráveis relacionados à utilização desse aditivo à base de LH, o que corrobora para a viabilidade e segurança do LH concentrado proposto nesta tese como alternativa para o adequado suporte nutricional do 
RNMBP durante o período de internação na UTIN (Cristofalo et al., 2013; Hair et al., 2014; Hair et al., 2016b; Sullivan et al, 2010).

\section{CONCLUSÃO}

A presente tese comprova a possibilidade de formulação do LH concentrado pasteurizado a partir de um método direto, simples, pouco oneroso e isento de viés ético de liofilização do LH maduro doado e sua utilização como aditivo natural do próprio LH, seguido de etapa final de pasteurização. Tal LH concentrado pasteurizado apresentou segurança microbiológica, osmolalidade aceitável e o aumento significativo da concentração de macro e micronutrientes essenciais, o que torna esse produto uma alternativa viável e segura para o adequado suporte nutricional do RNMBP durante o período de internação na UTIN. Além disso, os resultados desta tese permitirão atualizar as informações a respeito da composição do leite materno maduro proveniente de doadoras brasileiras e processado pelo BLH, informação que pode ser útil para demais rBLH do mundo.

Recentemente foi concluído o estudo clínico fase 1 (duplo-cego, randomizado e controlado) o qual avaliou a segurança, tolerabilidade e desempenho inicial do LH concentrado utilizado no suporte nutricional do RNMBP com a intenção de ser uma alternativa viável para o desuso dos aditivos comerciais à base de proteína do leite de vaca atualmente utilizados nas UTINs brasileiras. 


\section{REFERÊNCIAS}

AAP. American Academy of Pediatrics, Committee on Nutrition: Nutritional needs of lowbirth-weight infants. Pediatrics. 1985; 75(5):976-86.

AAP. American Academy of Pediatrics, Section on Breastfeeding. Breastfeeding and the use of human milk. Pediatrics. 2012; 129(3): e827-41. doi: 10.1542/peds.2011-3552.

Abrams SA, et al. Greater mortality and morbidity in extremely preterm infants fed a diet containing cow milk protein products. Breastfeed Med. 2014; 9(6):281-5. doi: 10.1089/bfm.2014.0024.

Agostoni C, et al. Enteral nutrient supply for preterm infants: Commentary from the European Society of Paediatric Gastroenterology, Hepatology and Nutrition Committee on Nutrition. J. Pediatr. Gastroenterol. Nutr. 2010, 50, 85-91. doi: 10.1097/MPG.0b013e3181adaee0.

Ahrabi AF, et al. Effects of extended freezer storage on the integrity of human milk. J Pediatr. 2016; 177:140-143. doi: 10.1016/j.jpeds.2016.06.024.

Albarrán JC, et al. [Impact of pasteurization/freeze-drying on available immunoglobulin content of the mature human milk. Use in human milk banking of hospitals]. Nutr Hosp. 2017; 34(4):899-906. doi: 10.20960/nh.627.

Andreas NJ, Kampmann B, Le-Doare KM. Human breast milk: A review on its composition and bioactivity. Early Hum Dev. 2015; 91(11), 629-35. doi: 10.1016/j.earlhumdev.2015.08.013.

Arslanoglu S, et al. Fortification of human milk for preterm Infants: Update and recommendations of the European Milk Bank Association (EMBA) Working group on human milk fortification. Front Pediatr. 2019; 7:76. doi: 10.3389/fped.2019.00076.

Asbury MR, et al. Optimizing the growth of very-low-birth-weight infants requires targeting both nutritional and nonnutritional modifiable factors specific to stage of hospitalization. Am J Clin Nutr. 2019;110(6):1384-1394. doi: 10.1093/ajcn/nqz227.

Assad M, Elliott MJ, Abraham JH. Decreased cost and improved feeding tolerance in VLBW infants fed an exclusive human milk diet. J Perinatol. 2016; 36(3), 216-20. doi: 10.1038/jp.2015.168.

Barness LA, et al. Commentary on breast-feeding and infant formulas, including proposed standards for formulas. Pediatrics. 1976; 57:278-85.

Belfort MB, Ehrenkranz RA. Neurodevelopmental outcomes and nutritional strategies in very low birth weight infants. Semin Fetal Neonatal Med. 2017; 22(1):42-48. doi: 10.1016/j.siny.2016.09.001.

Bertino E, et al. Benefits of donor milk in the feeding of preterm infants. Early Hum Dev. 2013; 89 Suppl 2, S3-6. doi: 10.1016/j.earlhumdev.2013.07.008. 
BLH-IFF/NT- 08.11- Ambiência: Manuseio do Rede Brasileira de Lixo e Material de Descarte, 2011. (Disponível em: https://rblh.fiocruz.br/normas-tecnicas-e-manuais. Acessado em: 24/06/2021).

BLH-IFF/NT-09.18 - Doadoras: Triagem, Seleção e Acompanhamento, 2018. (Disponível em: https://rblh.fiocruz.br/normas-tecnicas-e-manuais. Acessado em: 24/06/2021).

BLH-IFF/NT-16.11 - Ordenha: Procedimentos Higiênicos Sanitários, 2011. (Disponível em: https://rblh.fiocruz.br/normas-tecnicas-e-manuais. Acessado em: 24/06/2021).

BLH-IFF/NT-17.11 - Rotulagem do Rede Brasileira de Leite Humano Ordenhado Cru, 2011. (Disponível em: https://rblh.fiocruz.br/normas-tecnicas-e-manuais. Acessado em: 24/06/2021).

BLH-IFF/NT-18.11 - Pré-estocagem do Rede Brasileira de Leite Humano Ordenhado Cru, 2011. (Disponível em: https://rblh.fiocruz.br/normas-tecnicas-e-manuais. Acessado em: 24/06/2021).

BLH-IFF/NT-19.11 - Transporte do Rede Brasileira de Leite Humano Ordenhado, 2011. (Disponível em: https://rblh.fiocruz.br/normas-tecnicas-e-manuais. Acessado em: 24/06/2021).

BLH-IFF/NT-20.11 - Controle de Temperatura Rede Brasileira de das Caixas Isotérmicas, 2011. (Disponível em: https://rblh.fiocruz.br/normas-tecnicas-e-manuais. Acessado em: 24/06/2021).

BLH-IFF/NT-21.11 - Recepção do LHO Cru Rede Brasileira de em Bancos de Leite Humano, 2011. (Disponível em: https://rblh.fiocruz.br/normas-tecnicas-e-manuais. Acessado em: 24/06/2021).

BLH-IFF/NT-23.11 - Seleção e Classificação do Rede Brasileira de Leite Humano Ordenhado Cru, 2011. (Disponível em: https://rblh.fiocruz.br/normas-tecnicas-e-manuais. Acessado em: 24/06/2021).

BLH-IFF/NT-24.11 - Degelo do Leite Humano Ordenhado Cru, 2011. (Disponível em: https://rblh.fiocruz.br/normas-tecnicas-e-manuais. Acessado em: 24/06/2021).

BLH-IFF/NT-25.11 - Leite Humano Ordenhado Determinação da Cor, 2011. (Disponível em: https://rblh.fiocruz.br/normas-tecnicas-e-manuais. Acessado em: 24/06/2021).

BLH-IFF/NT-26.11 - Leite Humano Ordenhado: Determinação de Off-flavor - Método Sensorial, 2011. (Disponível em: https://rblh.fiocruz.br/normas-tecnicas-e-manuais. Acessado em: 24/06/2021)

BLH-IFF/NT-27.11 - Leite Humano Ordenhado: Rede Brasileira de Verificação de Sujidades, 2011. (Disponível em: https://rblh.fiocruz.br/normas-tecnicas-e-manuais. Acessado em: 24/06/2021).

BLH-IFF/NT-28.11 - Verificação da Embalagem para o Rede Brasileira de Leite Humano Ordenhado Cru, 2011. (Disponível em: https://rblh.fiocruz.br/normas-tecnicas-e-manuais. Acessado em: 24/06/2021). 
BLH-IFF/NT-29.11 - Leite Humano Ordenhado: Determinação da Acidez Titulável - Método Dornic, 2011. (Disponível em: https://rblh.fiocruz.br/normas-tecnicas-e-manuais. Acessado em: 24/06/2021).

BLH-IFF/NT-30.11 - Leite Humano Ordenhado: Determinação do Crematócrito, 2011. (Disponível em: https://rblh.fiocruz.br/normas-tecnicas-e-manuais. Acessado em: 24/06/2021).

BLH-IFF/NT-34.11 - Pasteurização do Leite Humano Ordenhado, 2011. (Disponível em: https://rblh.fiocruz.br/normas-tecnicas-e-manuais. Acessado em: 24/06/2021).

BLH-IFF/NT-40.11 - Teste Simplificado para Detecção de Coliformes Totais, 2011. (Disponível em: https://rblh.fiocruz.br/normas-tecnicas-e-manuais. Acessado em: 24/06/2021).

Book LS, et al. Necrotizing enterocolitis in low-birth-weight infants fed an elemental formula. J Pediatr. 1975; 87(4):602-5. doi: 10.1016/s0022-3476(75)80835-3.

Brasil. Ministério da Saúde. Agencia Nacional de Vigilância Sanitária. Resolução RDC nº 171, de 04 de setembro de 2006. Dispõe sobre o Regulamento Técnico para o funcionamento de Bancos de Leite Humano. Diário Oficial da União; Poder Executivo, de 05 de setembro de 2006. Disponível em: http://www.redeblh.fiocruz.br/. Acesso em: 28 de maio de 2020.

Agência Nacional de Vigilância Sanitária. Banco de leite humano: funcionamento, prevenção e controle de riscos/ Agência Nacional de Vigilância Sanitária. Brasília: Anvisa, 2008. 160 p. Disponível em: http://www.redeblh.fiocruz.br/. Acesso em: 28 de maio de 2020.

Constituição 1988. Constituição da República Federativa do Brasil de 1988. Brasília (DF): Presidência da República, 2016. Disponível em: http://www.planalto.gov.br/ccivil_03/Constituicao/Constituicao.htm. Acesso em: 24 de maio de 2020.

Brown JVE, et al. Multi-nutrient fortification of human milk for preterm infants. Cochrane Database Syst Rev. 2016; (5):CD000343. doi: 10.1002/14651858.CD000343.pub3.

Brown JVE, Walsh V, McGuire W. Formula versus maternal breast milk for feeding preterm or low birth weight infants. Cochrane Database Syst Rev. 2019; 8, CD002972. doi: 10.1002/14651858.CD002972.pub3.

Buffin R, et al. Better control of holder pasteurization results in higher retention of human milk lactoferrin, IgA, and lysozyme. Front Pediatr. 2018; 6:381. doi: 10.3389/fped.2018.00381.

Capriati T, et al. A modified holder pasteurization method for donor human milk: Preliminary data. Nutrients. 2019; 11(5):1139. doi: 10.3390/nu11051139.

Cerasani J, et al. Human milk feeding and preterm infants' growth and body composition: A literature review. Nutrients. 2020; 12(4):1155. doi: 10.3390/nu12041155.

Chandran S, et al. Medications that increase osmolality and compromise the safety of enteral feeding in preterm infants. Neonatology. 2017; 111(4):309-316. doi: 10.1159/000454667. 
Chang Y, Tseng Y, Chen K. The epidemiologic characteristics and associated risk factors of preterm birth from 2004 to 2013 in Taiwan. BMC Pregnancy Childbirth. 2020; 20(1):201. doi: 10.1186/s12884-020-02903-1.

Chawanpaiboon S, et al. Global, regional, and national estimates of levels of preterm birth in 2014: a systematic review and modelling analysis. Lancet Glob Health. 2019; 7(1): e37-e46. doi: 10.1016/S2214-109X(18)30451-0.

CMAJ. Nutrient needs and feeding of premature infants. Nutrition Committee, Canadian Paediatric Society 1995; 152(11):1765-85.

Colaizy TT, et al. Growth in VLBW infants fed predominantly fortified maternal and donor human milk diets: a retrospective cohort study. BMC Pediatr. 2012; 12, 124. doi: 10.1186/14712431-12-124.

Colaizy TT, et al. Impact of optimized breastfeeding on the costs of necrotizing enterocolitis in extremely low birth weight infants. J Pediatr. 2016; 175, 100-105.e2. doi: 10.1016/j.jpeds.2016.03.040.

Cormack BE, et al. Relationships between neonatal nutrition and growth to 36 weeks' corrected age in ELBW babies - Secondary cohort analysis from the provide trial. Nutrients. 2020; 12(3). pii: E760. doi: 10.3390/nu12030760.

Cortez MV, Soria EA. The effect of freeze-drying on the nutrient, polyphenol, and oxidant levels of breast milk. Breastfeed Med. 2016; 11:551-554. doi: 10.1089/bfm.2016.0102.

Cortez J, et al. Maternal milk feedings reduce sepsis, necrotizing enterocolitis and improve outcomes of premature infants. J Perinatol. 2018; 38(1), 71-74. doi: 10.1038/jp.2017.149.

Corvaglia L, et al. Standard fortification of preterm human milk fails to meet recommended protein intake: Bedside evaluation by near-infrared-reflectance-analysis. Early Hum Dev. 2010; 86(4):237-40. doi: 10.1016/j.earlhumdev.2010.04.001.

Coviello $\mathrm{C}$, et al. Effects of early nutrition and growth on brain volumes, white matter microstructure, and neurodevelopmental outcome in preterm newborns. Pediatr Res. 2018; 83(1-1):102-110. doi: 10.1038/pr.2017.227.

Cristofalo EA, et al. Randomized trial of exclusive human milk versus preterm formula diets in extremely premature infants. J Pediatr. 2013; 163(6):1592-1595. doi: 10.1016/j.jpeds.2013.07.011.

deRegnier R. Improving systems of care for preterm infants. J Pediatr. 2018; 196:1. doi: 10.1016/j.jpeds.2018.03.019.

Dutta S, Singh B, et al. Guidelines for feeding very low birth weight infants. Nutrients. 2015; 7(1), 423-442. doi: 10.3390/nu7010423.

Ellis Z, et al. Milk feed osmolality and adverse events in newborn infants and animals: A systematic review. Arch Dis Child Fetal Neonatal Ed. 2019; 104(3): F333-F340. doi: 10.1136/archdischild-2018-315946. 
Embleton NE, Pang N, Cooke RJ. Postnatal malnutrition and growth retardation: an inevitable consequence of current recommendations in preterm infants? Pediatrics. 2001; 107:270-3.

Fischer Fumeaux CJ, et al. Longitudinal analysis of macronutrient composition in preterm and term human milk: A prospective cohort study. Nutrients. 2019; 11(7):1525. doi: 10.3390/nu11071525.

Ganapathy V, Hay JW, Kim JH. Costs of necrotizing enterocolitis and cost-effectiveness of exclusively human milk-based products in feeding extremely premature infants. Breastfeed Med. 2012; 7(1):29-37. doi: 10.1089/bfm.2011.0002.

García-Lara NR, et al. Effect of freezing time on macronutrients and energy content of breastmilk. Breastfeed Med. 2012; 7(4):295-301. doi: 10.1089/bfm.2011.0079.

García-Lara NR, e al. Effect of holder pasteurization and frozen storage on macronutrients and energy content of breast milk. J Pediatr Gastroenterol Nutr. 2013; 57(3):377-82. doi: 10.1097/MPG.0b013e31829d4f82.

Gianni ML, Roggero P, Mosca F. Human milk protein vs. formula protein and their use in preterm infants. Curr Opin Clin Nutr Metab Care. 2019; 22(1):76-81. doi: 10.1097/MCO.0000000000000528.

Grance TRS, et al. [Homologous human milk supplement for very low birth weight preterm infant feeding]. Rev Paul Pediatr. 2015; 33(1):28-33. doi: 10.1016/j.rpped.2014.07.001.

Hahn W, et al. The human milk oligosaccharides are not affected by pasteurization and freezedrying. J Matern Fetal Neonatal Med. 2019; 32(6):985-991. doi: 10.1080/14767058.2017.1397122.

Hair $\mathrm{AB}$, et al. Human milk feeding supports adequate growth in infants $\leq 1250$ grams birth weight. BMC Res Notes. 2013; 6:459. doi: 10.1186/1756-0500-6-459.

Hair AB, et al. Randomized trial of human milk cream as a supplement to standard fortification of an exclusive human milk-based diet in infants 750-1250 g birth weight. J Pediatr. 2014; 165(5):915-20. doi: 10.1016/j.jpeds.2014.07.005.

Hair $\mathrm{AB}$, et al. Beyond necrotizing enterocolitis prevention: improving outcomes with an exclusive human milk-based diet. Breastfeed Med. 2016a; 11(2):70-4. doi: 10.1089/bfm.2015.0134.

Hair AB, et al. Premature infants 750-1,250 g birth weight supplemented with a novel human milk-derived cream are discharged sooner. Breastfeed Med. 2016b; 11:133-7. doi: 10.1089/bfm.2015.0166.

Hair AB, et al. Beyond necrotizing enterocolitis: other clinical advantages of an exclusive human milk diet. Breastfeed Med. 2018; 13(6):408-411. doi:10.1089/bfm.2017.0192.

Harding JE, et al. Advances in nutrition of the newborn infant. Lancet. 2017; 389(10079):16601668. doi: 10.1016/S0140-6736(17)30552-4. 
Harrison MS, Goldenberg RL. Global burden of prematurity. Semin Fetal Neonatal Med. 2016; 21(2):74-9. doi: 10.1016/j.siny.2015.12.007.

Hay WW Jr, et al. Workshop summary: nutrition of the extremely low birth weight infant. Pediatrics. 1999; 104(6):1360-8.

Hay WW Jr. Strategies for feeding the preterm infant. Neonatology. 2008; 94(4):245-54. doi: $10.1159 / 000151643$.

Hiltunen $\mathrm{H}$, et al. Early nutrition and growth until the corrected age of 2 years in extremely preterm infants. Neonatology. 2018; 113(2):100-107. doi: 10.1159/000480633.

Horbar JD, et al. Weight growth velocity and postnatal growth failure in infants 501 to 1500 grams: 2000-2013. Pediatrics. 2015; 136(1): e84-92. doi: 10.1542/peds.2015-0129.

Huston RK, et al. Improving growth for infants $\leq 1250$ grams receiving an exclusive human milk diet. Nutr Clin Pract. 2018; 33(5): 671-678. doi:10.1002/ncp.10054.

Ikonen R, et al. Preterm infants' mothers' initiation and frequency of breast milk expression and exclusive use of mother's breast milk in neonatal intensive care units. J Clin Nurs. 2018; 27(34): e551-e558. doi: 10.1111/jocn.14093.

$\mathrm{Kim} \mathrm{MH}$, et al. Macronutrient analysis of human milk according to storage and processing in Korean mother. Pediatr Gastroenterol Hepatol Nutr. 2019; 22(3):262-269. doi: 10.5223/pghn.2019.22.3.262.

Koletzko B, Poindexter B, Uauy R. Recommended nutrient intake levels for stable, fully enterally fed very low birth weight infants. World Rev Nutr Diet. 2014; 110:297-9. doi: $10.1159 / 000360195$.

Koo W, Tice H. Human milk fortifiers do not meet the current recommendation for nutrients in very low birth weight infants. JPEN J Parenter Enteral Nutr. 2018; 42(4):813-820. doi: $10.1177 / 0148607117713202$.

Kreissl A, et al. Effect of fortifiers and additional protein on the osmolarity of human milk: is it still safe for the premature infant? J Pediatr Gastroenterol Nutr. 2013; 57(4):432-7. doi: 10.1097/MPG.0b013e3182a208c7.

Kumar RK, et al. Optimizing nutrition in preterm low birth weight infants-consensus summary. Front Nutr. 2017; 4:20. doi: 10.3389/fnut.2017.00020.

Kumar J, Yadav A. Evaluation of human milk fortifiers in preterm infants. J Pediatr. 2019; 205:291. doi: 10.1016/j.jpeds.2018.10.071.

Laelago T, Yohannes T, Tsige G. Determinants of preterm birth among mothers who gave birth in East Africa: systematic review and meta-analysis. Ital J Pediatr. 2020; 46(1):10. doi: 10.1186/s13052-020-0772-1. 
Lewis ED, et al. The importance of human milk for immunity in preterm infants. Clin Perinatol. 2017; 44(1):23-47. doi: 10.1016/j.clp.2016.11.008.

Lönnerdal B. Bioactive proteins in human milk - Potential benefits for preterm infants. Clin Perinatol. 2017; 44(1):179-191. doi: 10.1016/j.clp.2016.11.013.

Loui A, et al. Calcium, Phosphorus and Magnesium balance: FM 85 fortification of human milk does not meet mineral needs of extremely low birthweight infants. Eur J Clin Nutr. 2002; 56(3):228-35. doi: 10.1038/sj.ejcn.1601305.

Lozano B, et al. Vitamins, fatty acids, and antioxidant capacity stability during storage of freeze-dried human milk. Int J Food Sci Nutr. 2014; 65(6):703-7. doi: 10.3109/09637486.2014.917154.

Lucas A, et al. A human milk formula. Early Hum Dev. 1980; 4(1):15-21. doi: 10.1016/03783782(80)90004-3.

Martin CR, et al. Nutritional practices and growth velocity in the first month of life in extremely premature infants. Pediatrics. 2009; 124(2):649-57. doi: 10.1542/peds.2008-3258.

Martinez FE, Camelo Jr JS. [Nutrition of the preterm infants]. J Pediatr (Rio J). 2001;77 Suppl 1:S32-40.

McNelis K, Fu TT, Poindexter B. Nutrition for the extremely preterm infant. Clin Perinatol. 2017; 44 (2):395-406. doi: 10.1016/j.clp.2017.01.012.

Miller M, et al. From parenteral to enteral nutrition: a nutrition-based approach for evaluating postnatal growth failure in preterm infants. JPEN J Parenter Enteral Nutr. 2014; 38(4):489-97. doi: $10.1177 / 0148607113487926$.

Morlacchi L, et al. Protein use and weight-gain quality in very-low-birth-weight preterm infants fed human milk or formula. Am J Clin Nutr. 2018; 107(2):195-200. doi: 10.1093/ajcn/nqx001.

Moro GE, et al. Processing of donor human milk: Update and recommendations from the European Milk Bank Association (EMBA). Front Pediatr. 2019; 7:49. doi: 10.3389/fped.2019.00049.

Mosca F, Giannì ML. Human milk: composition and health benefits. Pediatr Med Chir. 2017; 39(2):155. doi: 10.4081/pmc.2017.155.

Novak FR, Almeida JAG. [Alternative test for detection of coliforms bacteria in manually expressed human milk]. J Pediatr (Rio J). 2002; 78(3):193-6. doi: 10.2223/jped.829.

Patra K, et al. NICU human milk dose and 20-Month neurodevelopmental outcome in very low birth weight infants. Neonatology. 2017; 112(4), 330-336. doi: 10.1159/000475834.

Pearson F, Johnson MJ, Leaf AA. Milk osmolality: Does it matter? Arch Dis Child Fetal Neonatal Ed. 2013; 98(2): F166-9. doi: 10.1136/adc.2011.300492. 
Peila C, et al. The effect of Holder Pasteurization on nutrients and biologically-active components in donor human milk: A review. Nutrients. 2016; 8(8):477. doi: 10.3390/nu8080477.

Perrella SL, et al. Influences of breast milk composition on gastric emptying in preterm infants. J Pediatr Gastroenterol Nutr. 2015; 60(2):264-71. doi: 10.1097/MPG.0000000000000596.

Picaud J, Buffin R. Human milk-treatment and quality of banked human milk. Clin Perinatol. 2017; 44(1):95-119. doi: 10.1016/j.clp.2016.11.003.

Premkumar MH, Pammi M, Suresh G. Human milk-derived fortifier versus bovine milkderived fortifier for prevention of mortality and morbidity in preterm neonates. Cochrane Database Syst Rev. 2019; 2019(11). doi: 10.1002/14651858.CD013145.

Prolacta [prolacta.com]. Monrovia, California, United States of America: Prolacta Bioscience. Disponível em: https://www.prolacta.com/.

Purisch SE, Gyamfi-Bannerman C. Epidemiology of preterm birth. Semin Perinatol. 2017; 41(7):387-391. doi: 10.1053/j.semperi.2017.07.009.

Quigley M, Embleton ND, McGuire W. Formula versus donor breast milk for feeding preterm or low birth weight infants. Cochrane Database Syst Rev. 2019; 7:CD002971. doi: 10.1002/14651858.CD002971.pub5.

Raiten DJ, Steiber AL, Hand RK. Executive summary: evaluation of the evidence to support practice guidelines for nutritional care of preterm infants-the Pre-B Project. Am J Clin Nutr. 2016; 103 (2):599S-605S. doi: 10.3945/ajcn.115.124222.

Rochow N, et al. Target fortification of breast milk with fat, protein, and carbohydrates for preterm infants. J Pediatr. 2013; 163(4):1001-7. doi: 10.1016/j.jpeds.2013.04.052.

Rosas R, et al. Experimental study showed that adding fortifier and extra-hydrolysed proteins to preterm infant mothers' milk increased osmolality. Acta Paediatr. 2016; 105(12):e555-e560. doi: 10.1111/apa.13522.

Sammallahti S, et al. Nutrition after preterm birth and adult neurocognitive outcomes. PLoS One. 2017; 12(9), e0185632. doi: 10.1371/journal.pone.0185632.

Schanler RJ, et al. Improved outcomes in preterm infants fed a nonacidified liquid human milk fortifier: A Prospective Randomized Clinical Trial. J Pediatr. 2018; 202:31-37. e2. doi: 10.1016/j.jpeds.2018.07.005.

Schneider J, et al. Nutrient intake in the first two weeks of life and brain growth in preterm neonates. Pediatrics. 2018; 141(3): e20172169. doi: 10.1542/peds.2017-2169.

Seiiedi-Biarag L, Mirghafourvand M. The effect of massage on feeding intolerance in preterm infants: a systematic review and meta-analysis study. Ital J Pediatr. 2020; 46(1):52. doi: 10.1186/s13052-020-0818-4. 
Sethi A, et al. A quality improvement initiative: Improving exclusive breastfeeding rates of preterm neonates. Indian J Pediatr. 2017; 84(4):322-325. doi: 10.1007/s12098-017-2306-4.

Sousa SG, Delgadillo I, Saraiva JA. Effect of thermal pasteurisation and high-pressure processing on immunoglobulin content and lysozyme and lactoperoxidase activity in human colostrum. Food Chem. 2014; 151:79-85. doi: 10.1016/j.foodchem.2013.11.024.

Stephens BE, et al. First-week protein and energy intakes are associated with 18-month developmental outcomes in extremely low birth weight infants. Pediatrics. 2009; 123(5):133743. doi: 10.1542/peds.2008-0211.

Sullivan S, et al. An exclusively human milk-based diet is associated with a lower rate of necrotizing enterocolitis than a diet of human milk and bovine milk-based products. J Pediatr. 2010; 156(4):562-7. e1. doi: 10.1016/j.jpeds.2009.10.040.

Thakkar SK, et al. Temporal progression of fatty acids in preterm and term human milk of mothers from Switzerland. Nutrients. 2019;11(1):112. doi: 10.3390/nu11010112.

Tanriverdi S, et al. Evaluation of macronutrient content of fresh and frozen human milk over 6 months. J Matern Fetal Neonatal Med. 2019; 1-8. doi: 10.1080/14767058.2019.1651269.

Thomaz DMC, et al. Comparison between homologous human milk supplements and a commercial supplement for very low birth weight infants. J Pediatr (Rio J). 2012; 88(2):11924. doi: 10.2223/JPED.2166.

Tudehope D, et al. Nutritional needs of the micropreterm infant. J Pediatr. 2013; 162(3 Suppl): S72-80. doi: 10.1016/j.jpeds.2012.11.056.

Valentine CJ, et al. Lactational stage of pasteurized human donor milk contributes to nutrient limitations for infants. Nutrients. 2017; 9(3). pii: E302. doi: 10.3390/nu9030302.

Victora JD, et al. Prevalence, mortality and risk factors associated with very low birth weight preterm infants: an analysis of 33 years. J Pediatr (Rio J). 2018. pii: S0021-7557(18)30631-4. doi: 10.1016/j.jped.2018.10.011.

Villar J, et al. Postnatal growth standards for preterm infants: The Preterm Postnatal Follow-up Study of the INTERGROWTH-21st Project. Lancet Glob Health. 2015 ;3: e681-91. doi: 10.1016/S2214-109X (15)00163-1.

Vohr BR, et al. Beneficial effects of breast milk in the neonatal intensive care unit on the developmental outcome of extremely low birth weight infants at 18 months of age. Pediatrics. 2006; 118(1): e115-23.

Waard M, et al. Holder-pasteurized human donor milk: how long can it be preserved? J Pediatr Gastroenterol Nutr. 2018; 66(3):479-483. doi: 10.1097/MPG.0000000000001782.

Walker A. Breast milk as the gold standard for protective nutrients. J Pediatr. 2010; 156(2 Suppl), S3-7. doi: 10.1016/j.jpeds.2009.11.021. 
Wesolowska A, et al. Innovative techniques of processing human milk to preserve key components. Nutrients. 2019; 11(5):1169. doi: 10.3390/nu11051169.

Westin V, et al. Improved nutrition for extremely preterm infants - A population based observational study. Clin Nutr ESPEN. 2018; 23:245-251. doi: 10.1016/j.clnesp.2017.09.004.

WHO, 2012. Born Too Soon: The Global action report on preterm Birth. Eds CP Howson, MV Kinney, JE Lawn. World Health Organization. Geneva.

WHO, 2019. Survive and thrive: transforming care for every small and sick newborn. Geneva: World Health Organization. 


\section{ANEXOS}

O anexo a seguir é referente ao estudo clínico fase 1 (duplo-cego, randomizado e controlado) no qual atuei como pesquisadora na avaliação da segurança e tolerabilidade do LH concentrado utilizado no suporte nutricional do RNMBP. O resumo do estudo foi publicado em dois renomados eventos internacionais, a International Conference on Clinical Neonatology 2020 e o Grand Challenges Global Meeting 2020. Recentemente, o resumo do trabalho também foi submetido ao United Nations Science, Technology and Innovation Forum 2021. O estudo completo já está em fase de submissão e será publicado em breve.

Seguem as referências bibliográficas das publicações acima citadas:

J.S. Camelo Jr. ${ }^{1}$, M.C. Achcar ${ }^{1}$, A. Carnevale-Silva ${ }^{1}$, M.M. Mussi ${ }^{1}$, F. Carmona ${ }^{1}$, D.C. Aragón, F. Ued ${ }^{1}$, M. Oliveira ${ }^{1}$, L.M. Monti ${ }^{2}$, V. Bonfim ${ }^{3}$, L.G. Alves ${ }^{3}$, A. Heck ${ }^{3}$, F.E Martinez ${ }^{1}$, V. Nogueira-Pileggi ${ }^{1}$. The Project Lioneo: Nutrition of Very Low Birthweight Newborns Using a Concentrate with Human Milk Lyophilisate: Phase 1 Study for Safety and Tolerability. International Conference on Clinical Neonatology 2020, Torino, Italy, virtual, published as a Selected Abstract in the American Journal of Perinatology: Am J Perinatol 2020; 37(S 02): S89-S100 (doi:10.1055/s-0040-1716981).

J.S. Camelo Jr. ${ }^{1}$, M.C. Achcar ${ }^{1}$, A. Carnevale-Silva ${ }^{1}$, M.M. Mussi ${ }^{1}$, F. Carmona ${ }^{1}$, D.C. Aragón, F. Ued ${ }^{1}$, M. Oliveira ${ }^{1}$, L.M. Monti ${ }^{2}$, V. Bonfim ${ }^{3}$, L.G. Alves ${ }^{3}$, A. Heck ${ }^{3}$, F.E Martinez ${ }^{1}$, V. Nogueira-Pileggi ${ }^{1}$. The Project Lioneo: Nutrition of Very Low Birthweight Newborns Using a Concentrate with Human Milk Lyophilisate: Phase 1 Study for Safety and Tolerability. Grand Challenges Global Meeting 2020, virtual, Abstract published in the Gates Open Research: Gates Open Res 2020, 4:133 (poster) (doi:10.21955/gatesopenres.1116671.1). 


\section{PROJECT LIONEO: NUTRITION OF VERY LOW BIRTH WEIGHT NEWBORNS USING A CONCENTRATE WITH HUMAN MILK LYOPHILISATE - PHASE 1 STUDY FOR SAFETY AND TOLERABILITY}

Authors: J.S. Camelo Jr. ${ }^{1}$, M.C. Achcar ${ }^{1}$, A. Carnevale-Silva ${ }^{1}$, M.M. Mussi ${ }^{1}$, F. Carmona ${ }^{1}$, D.C. Aragón, F. Ued ${ }^{1}$, M. Oliveira ${ }^{1}$, L.M. Monti ${ }^{2}$, V. Bonfim ${ }^{3}$, L.G. Alves ${ }^{3}$, A. Heck ${ }^{3}$, F.E Martinez ${ }^{1}$, V. Nogueira-Pileggi ${ }^{1}$.

Affiliations: 1. Depart. Pediatrics, Ribeirão Preto Medical School, University of São Paulo; Ribeirão Preto Nursing School, University of São Paulo; 3. Human Milk Bank, Clinics Hospital, Ribeirão Preto Medical School, University of São Paulo.

Introduction: A human milk concentrate using lyophilizate from banked human milk has been recently developed. Preclinical tests showed that the human milk with human lyophilisate has an adequate nutrient composition, physical-chemical and bacteriological stability, immediately and after 3 and 6 months stored in freezer -20 degrees Celsius. This study aims to assess safety and tolerability of the human milk with human milk additive compared to the standard additive (cow's protein milk). Materials and Methods: The study is a double-blind, randomized, controlled clinical trial. 40 very low birth weight infants (VLBWI) were divided in 2 groups, human milk plus human lyophilizate (LioNeo) and human milk plus commercial additive (LHFM85). Inclusion criteria: preterm babies ( $<37$ weeks GA), birth weight 750-1500g, small or adequate for gestational age, receiving exclusively human milk, volume equals to $100 \mathrm{~mL} / \mathrm{kg} /$ day or higher, hemodynamically stable, and whose parents or responsibles signed the informed consent. Exclusion criteria were large for gestational age, malformations, grade III and IV for peri and intraventricular hemorrhages and children from underage mothers without a responsible companion. Participants were computer randomly assigned to receive either LioNeo or LHFM85 during 21 consecutive days. Main outcomes: Necrotizing enterocolitis (NEC), late-onset neonatal sepsis and death, gastrointestinal bleeding and perforation, diarrhea, regurgitation, vomiting, abdominal distension (>10\%). Results: The main characteristics were similar between the groups: $1220 \pm 200 \mathrm{~g}$ and $30.4 \pm 2,7 \mathrm{w}$ GA for LioNeo group and $1219 \pm 204 \mathrm{~g}$ and $29.7 \pm 1.8 \mathrm{w}$ GA for LCFM85 group at baseline. The regression model 
based on a double Poisson distribution showed no differences between groups comparing the means of adverse outcomes. Diarrhea, gastrointestinal perforation, NEC and neonatal sepsis were not observed in the group LioNeo and therefore were not statistically compared (1 late onset sepsis and 1 NEC in group LCFM85). We also compared groups using a regression model with total volume of milk as an adjusted variable and there were no differences between the groups. We had no deaths during the study. Babies from both groups grew up similarly. Conclusion: The lyophilizate of human milk was considered safe and tolerable to use in hemodynamically stable VLBWI.

Key words: Human milk; human milk bank; preterm newborn; lyophilisate; very low birth weight infants.

Conflicts of interest: None declared. 